CONTRACTOR REPORT

SAND81-7154

Unlimited Release

UC-70

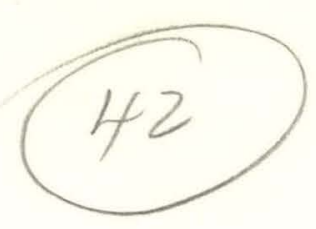

SAND--81-7154

DE82 011112

Field Examination of Shale and Argillite in Northern Nye County, Nevada E

James R. Connolly, Lee A. Woodward, Karl M. Emanuel

Klaus Keil

University of New Mexico

Albuquerque, NM 87131

Prepared by Sandia National Laboratories Albuquerque, New Mexico 87185 and Livermore, California 94550 for the United States Department of Energy under Contract DE-AC04-76DP00789

Prinled Decomber 1981 


\section{DISCLAIMER}

This report was prepared as an account of work sponsored by an agency of the United States Government. Neither the United States Government nor any agency Thereof, nor any of their employees, makes any warranty, express or implied, or assumes any legal liability or responsibility for the accuracy, completeness, or usefulness of any information, apparatus, product, or process disclosed, or represents that its use would not infringe privately owned rights. Reference herein to any specific commercial product, process, or service by trade name, trademark, manufacturer, or otherwise does not necessarily constitute or imply its endorsement, recommendation, or favoring by the United States Government or any agency thereof. The views and opinions of authors expressed herein do not necessarily state or reflect those of the United States Government or any agency thereof. 


\section{DISCLAIMER}

Portions of this document may be illegible in electronic image products. Images are produced from the best available original document. 
Issued by Sandia National Laboratories, operated for the United States Department of Energy by Sandia Corporation.

NOTICE: This report was prepared as an account of work sponsored by an agency of the United States Government. Neither the United States Government nor any agency thereof, nor any of their employees, nor any of their contractors, subcontractors, or their employees, makes any warranty, express or implied, or assumes any legal liability or responsibility for the accuracy, completeness, or usefulness of any information, apparatus, product, or process disclosed, or represents that its use would not infringe privately owned rights. Reference herein to any specific commercial product, process, or service by trade name, trademark, manufacturer, or otherwise, does not necessarily constitute or imply its endorsement, recommendation, or favoring by the United States Government, any agency thereof or any of their contractors or subcontractors. The views and opinions expressed herein do not necessarily state or reflect those of the United States Government, any agency thereof or any of their contractors or subcontractors.

Printed in the United States of America Available from

Available from

National Technical Information Service

U.S. Department of Commerce

5285 Port Royal Road

Springfield, VA 22161

NTIS price codes

Printed copy: $\$ 10.00$

Microfiche copy: A01 
SAND81-7154

Unlimited Release

Distribution

Printed December 1981

Category UC-70

\title{
FIELD EXAMINATION OF SHALE AND ARGILLITE \\ IN NORTHERN NYE COUNTY, NEVADA*
}

\author{
James R. Connolly \\ Lee A. Woodward \\ Kar1 M. Emanue1 \\ Klaus Keil \\ Department of Geology \\ and \\ Institute of Meteoritics \\ University of New Mexico. \\ Albuquerque, NM 87131
}

\begin{abstract}
Thirty-two locales underlain by clay-rich strata ranging from Cambrian Pioche Shale to Mississippian Chainman Shale and equivalents were examined in northern Nye County, Nevada. The text of the report summarizes data for each stratigraphic unit examined. Checklists for tabulating field data at each locale are included in an appendix. Working guidelines used to evaluate the locales include a minimum thickness of $150 \mathrm{~m}$ ( $500 \mathrm{ft}$ ) of relatively pure clay-rich bedrock, subsurface depth between $150 \mathrm{~m}(500 \mathrm{ft})$ and $900 \mathrm{~m}$ $(3000 \mathrm{ft})$, low topographic relief, low seismic and tectonic activity, and avoidance of areas with mineral resource produrtion or potential. Field studies indicate that only the Chainman Shale, specitically in the central and northern parts of the Pancake Range, appears to contain sites that meet these guidelines.
\end{abstract}

The work described in this report was performed for Sandia Laboratories under Contract No. 13-4004. 


\section{ACKNOWLEDGMENTS}

We thank R. W. Lynch (4530), L. D. Tyler and A. R.

Lappin (4537) for their guidance throughout this work, and G. L. Dixon and H. E. Simpson of the US Geological Survey for their help and advice. 


\section{DISCLAIMER}

This report was prepared as an account of work sponsored by an agency of the United States Government. Neither the United States Government nor any agency thereof, nor , any of their employees, make any warranty, express or implied, or assumes any legal liability or responsibility for the accuracy, completeness, or usefulness of any information, apparatus, product, or process disclosed, or represents that its use would not infringe privately owned rights. Reference herein to any specific commercial product, process, or service by trade name, trademark, manufacturer, or otherwise does not necessarily constitute or imply its endorsement, recommendation, or favoring by the United States Government or any agency thereof. The views and opinions of authors expressed herein do not necessarily state or reflect those of the United States Government or any agency thereof. 


\section{DISCLAIMER}

Portions of this document may be illegible in electronic image products. Images are produced from the best available original document. 


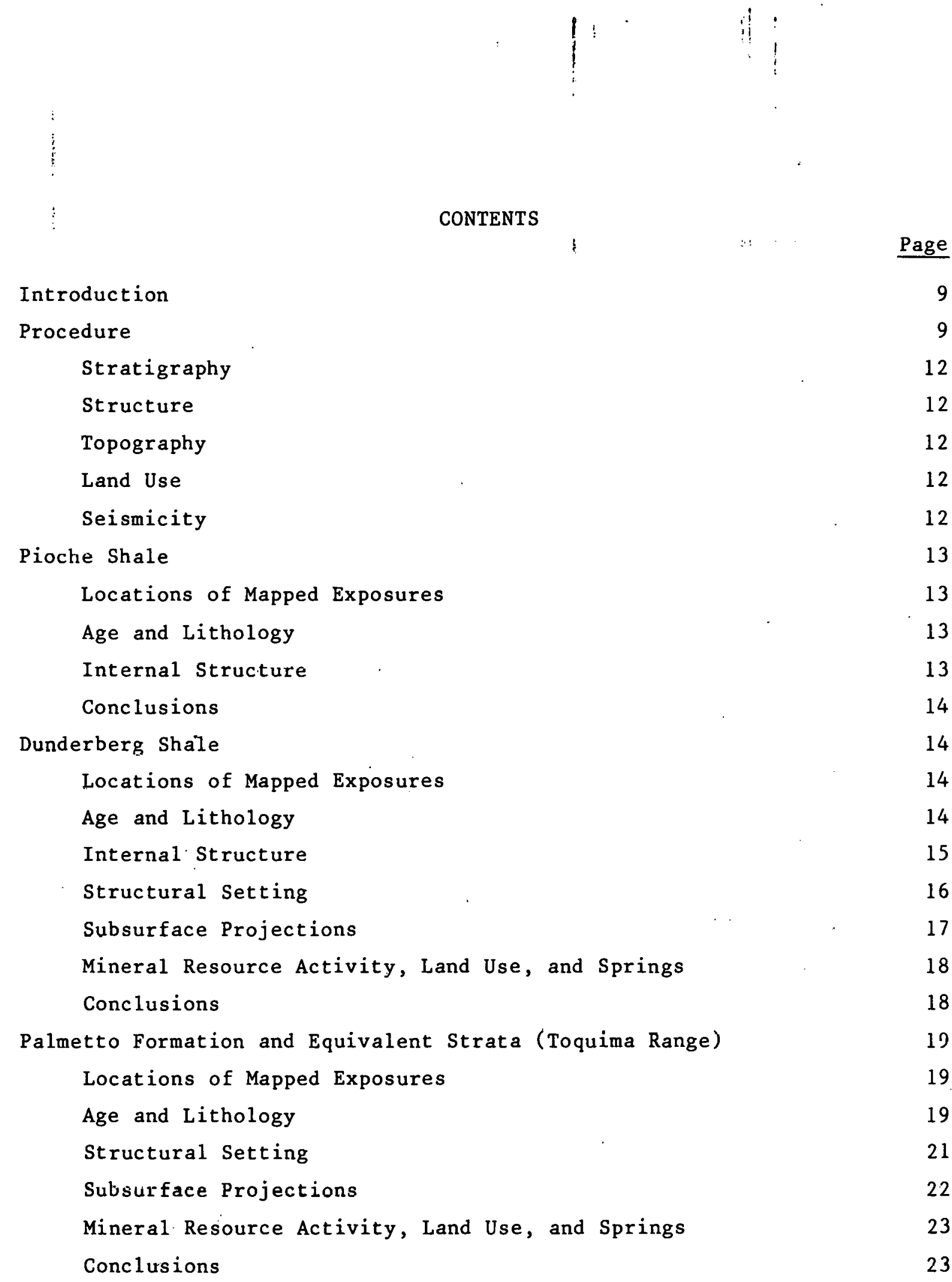


CONTENTS (cont)

Page

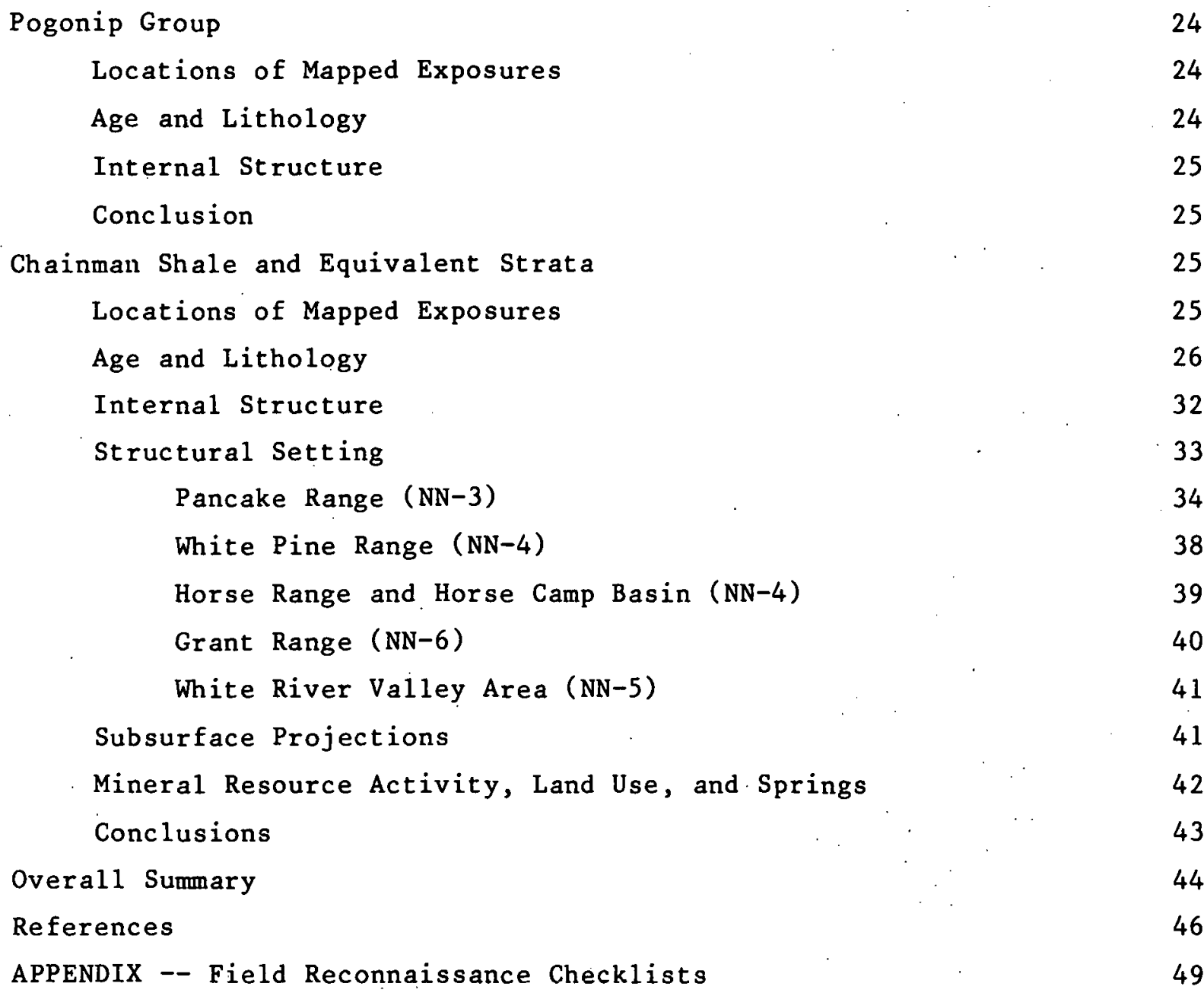

\section{ILLUSTRATIONS}

Figure

Page

1 Index Map Showing Clay-Rich Bedrock Locales

in Northern Nye County, Nevada.

2 Geologic Map of the Portuguese Spring Area $(\mathrm{NN}-3 \mathrm{~B})$, Nye County, Nevada

3 Geologic Map of Duckwater Peak Area (NN-3E), Nye and White Pine Counties, Nevada 


\section{ILLUSTRATIONS (cont)}

$\underline{\text { Figure }}$

$\underline{\text { Page }}$

4 Geologic Sketch Map of Duckwater Hills, Nye County, Nevada

5 Geologic Sketch Map of Big Louie West Area (NN-3D), Pancake Range, Nye County, Nevada

6 Generalized Restored Cross Section Through Western Part of Antler Foreland Basin in Late Mississippian Time; Chainman Shale of the Pancake Range Deposited Near Flysch Trough-Starved Basin Boundary

7 Chainman Shale Exposed in Portuguese Spring Area, Pancake Range (NN-3B)

8 Typical "Park"-Type Chainman Shale Exposure in Pancake Range (NN-3D)

9 Klippe of Devil's Gate Limestone (Devonian) Overlying Chainman Shale (Mississippian) West of Big Louie Spring, Pancake Range (NN-3D)

10 Thrust Fault Exposed in the Duckwater Hills, Pancake Range (NN-3C)

11 Chainman Shale Exposed North of Duckwater Peak, Pancake Range (NN-3E)

TABLES

Table

1 Shale-Argillite Sites in Northern Nye County, Nevada

2 Lithologic Summary of Chainman Shale and Eleana

Formation, Northern Nye County, Nevada 


\section{FIELD EXAMINATION OF SHALE AND ARGILLITE \\ IN NORTHERN NYE COUNTY, NEVADA}

\section{Introduction}

This project involves field examination of shale and argillite locales (Figure 1, Table 1) in northern Nye County, Nevada that were identified by simpson and others ${ }^{1}$ mainly by study of published geologic literature. Woodward and Connolly conducted field reconnaissance in May 1979, and Connolly and Emanuel. made a mure detailed examination of field occurrences in June and July 1979.

Previous geologic work is cited in appropriate discussions of the various locales examined. In general, only 1 imited studies have been conducted in the past in this region, and the preliminary geologic map of northern Nye County ${ }^{2}$ was used extensively.

Field data for this project were recorded on a checklist for each locale (see appendix); the information obtained is summarized in the body of this report. The locales are presented in stratigraphic order from oldest to youngest beginning with the Pioche Shale (Cambrian), continuing through Dunderberg Shale (Cambrian), Palmetto Formation (and equivalents, Cambro-Ordovician), Pogonip Group (Ordovician), and the Chainman ShaleEleana Formation (Mississippian). Figure 1 shows the locations referred to in the text.

\section{Procedure}

In order to compare and evaluate the various rock units identified by Simpson and others, 1 several working guidelines were considered. These guidelines were modified from those used by Shurr ${ }^{3}$ and are listed below: 
Shale-Argillite Sites in Northern Nye County, Nevada

Locales (from Reference

1)

\begin{tabular}{|c|c|c|c|c|c|c|c|}
\hline Stratigraphic Unit & 垔 & 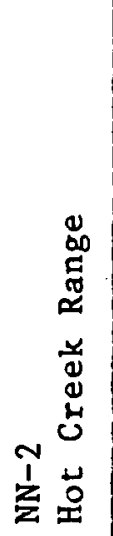 & 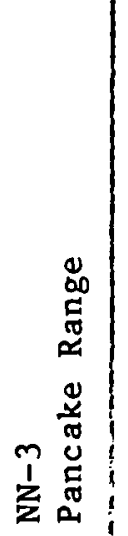 & 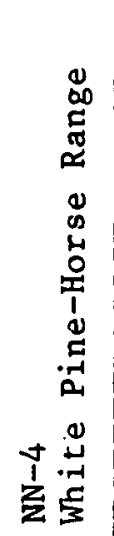 & 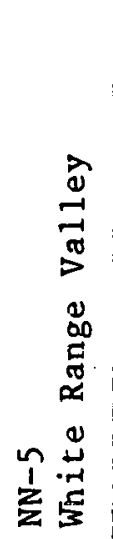 & 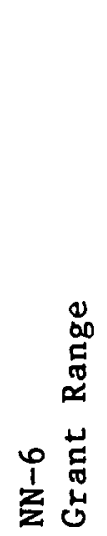 & 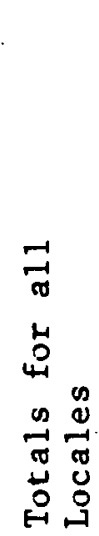 \\
\hline $\begin{array}{l}\text { Pioche Shale } \\
\text { Areas mapped } \\
\text { Examined here }\end{array}$ & & & & & & $\begin{array}{l}2 \\
2\end{array}$ & $\begin{array}{l}2 \\
2\end{array}$ \\
\hline $\begin{array}{l}\text { Dunderberg. Shale } \\
\text { Areas mapped } \\
\text { Examined here }\end{array}$ & & $3^{2}$ & & $\begin{array}{l}3 \\
0\end{array}$ & & & $\begin{array}{l}5 \\
3\end{array}$ \\
\hline $\begin{array}{l}\text { Palmetto Formation } \\
\text { (and Equivalents) } \\
\text { Areas mapped } \\
\text { Examined here }\end{array}$ & $\begin{array}{l}8 \\
7 \\
b\end{array}$ & & & & & & $\begin{array}{l}8 \\
7\end{array}$ \\
\hline $\begin{array}{l}\text { Ninemile Formation } \\
\text { (Pogonip Group) } \\
\text { Areas mapped } \\
\text { Examined here }\end{array}$ & & & & $\begin{array}{l}3 \\
1\end{array}$ & & $\begin{array}{r}13 \\
2\end{array}$ & $\begin{array}{r}16 \\
3\end{array}$ \\
\hline $\begin{array}{c}\text { Chainman Shale and } \\
\text { Eleana Formation } \\
\text { Areas mapped } \\
\text { Examined here }\end{array}$ & & $\begin{array}{l}6 \\
4^{b}\end{array}$ & $\begin{array}{l}9 \\
6^{c}\end{array}$ & $\begin{array}{l}5 \\
1\end{array}$ & $\begin{array}{l}6 \\
4\end{array}$ & $\begin{array}{l}9 \\
2\end{array}$ & $\begin{array}{l}35 \\
17\end{array}$ \\
\hline
\end{tabular}

NOTES: ${ }^{a}$ On Preliminary Geologic Map of Northern Nye County, Nevada (Reference 2). Closely spaced small outcrop b area have been counted as one

b Includes parts of one large area observed at two separate locations

${ }^{c}$ Includes two areas partly within White Pine County 


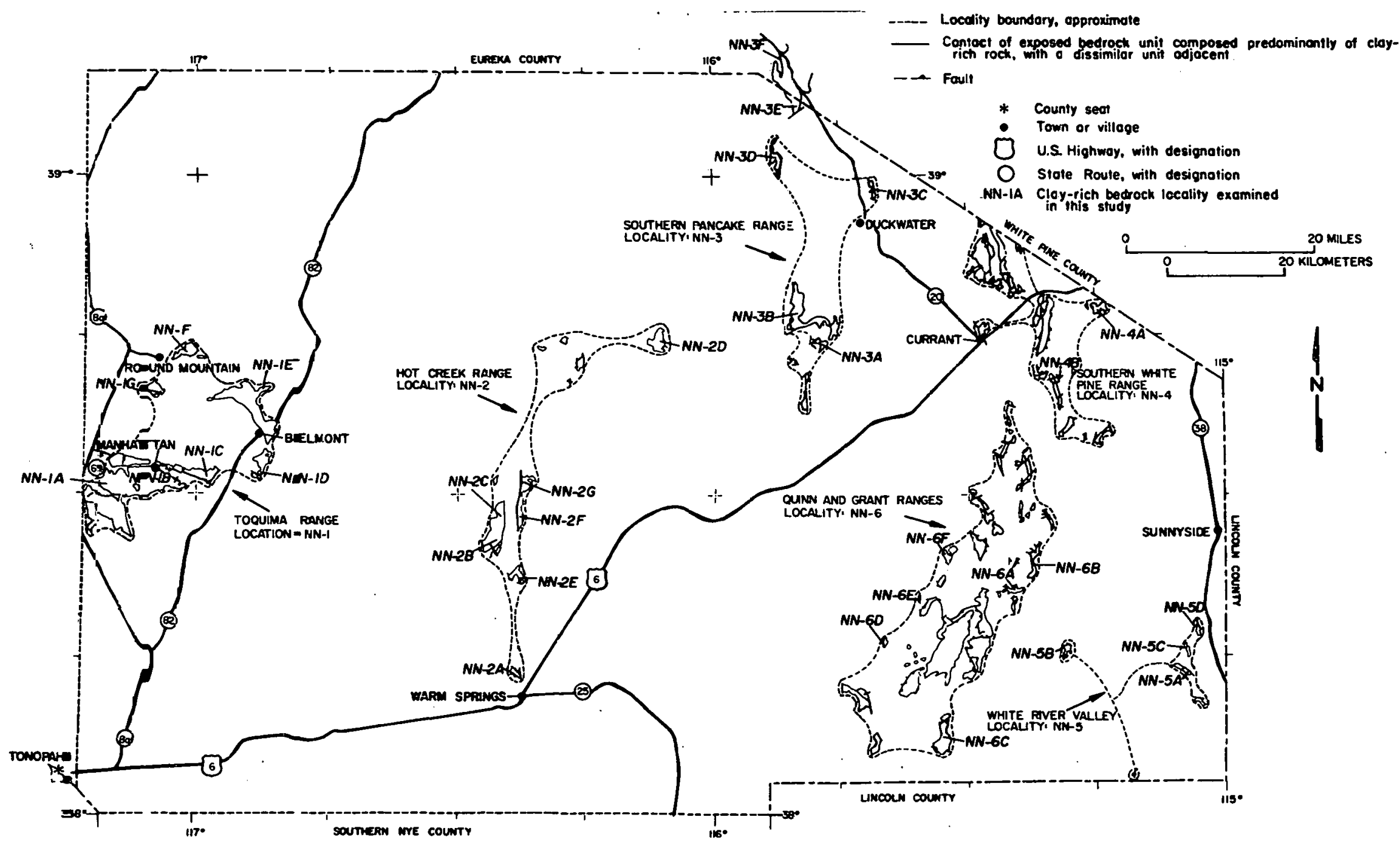

Figure 1. Index Map Showing Clay-Rich Bedrock Locales in Northern Nye County, Nevada 


\section{Stratigraphy}

A minimum $150 \mathrm{~m}(500 \mathrm{ft})$ thickness of a relatively pure clay-rich bedrock (or metamorphic derivative) is required. A high percentage ( $-25 \%$ or more) interbedded coarser grained clastic rock or limestone is considered unacceptable. In view of the tendency of major aquifers to be associated with carbonates, 4 1imestones are particularly unfavorable.

\section{Structure}

Internal deformation is ubiquitous in pre-Tertiary bedrock exposed in northern Nye County; requiring undeformed strata would all but eliminate any clay-rich strata from further consideration. As discussed later, internal deformation may not be critical to the desirable properties of low permeability and (although described in this report) it is not considered a preemptive criterion. Subsurface projections should ideally place strata at a depth between $>150 \mathrm{~m}(500 \mathrm{ft})$ and $<900 \mathrm{~m}(3000 \mathrm{ft})$.

\section{Topography}

Surface relief should be as low as possible. For this reason, most exposures examined are near range boundaries where subsurface projections into topographically low areas are possible. In much of the Pancake Range, terrain is more low hills than rugged mountains; consequently, numerous areas within the range were examined.

Land Use

Most of northern Nye County is uninhabited. Areas to be avoided are those with a history of mining activity.

\section{Seismicity}

Most ranges in northern Nye County owe their existence to Tertiary and Quaternary faulting. Attempts were made to subjectively evaluate this in the discussions of structural setting based on consideration of fault scarps in alluvium, steepness of canyons in ranges, and relief 
between basins and adjacent ranges. Any further evaluation of seismicity is beyond the scope of this report.

\section{Pioche Shale}

Locations of Mapped Exposures

Two areas underlain by Pioche Shale that were examined are on the west flank of the Grant Range adjacent to Railroad Valley, both north and south of the Troy Canyon quartz monzonite intrusive. These are the only Pioche Shale outcrops differentiated by Kleinhampl and $\mathrm{Ziony}{ }^{2}$ other areas of Pioche Shale are included with undifferentiated Cambrian-Ordovician limestones and shales.

Age and Lithology

The Pioche Shale is believed to be Early to Middle Cambrian based on regional correlations. 5 In both areas, the Pioche Shale consists of subequal amounts of slaty limestone, calcareous siltite, and slate or phyl1ite. Near Troy Canyon (Figure 1, Loc NN-6E), phyllitic textures dominate and rocks are locally schistose. In the Mud Spring area (Figure 1, Loc NN6 F), metamorphic textural grade tends to be somewhat lower, with most exposures slaty or weakly phyllitic. The degree of metamorphism in both areas suggests that the presence of clay minerals is unlikely other than in weachered near-surface exposures.

\section{Internal Structure}

The Troy Canyon exposures are within a fault slice west of the stratigraphically overlying Pole Canyon Limestone; Cebul1 ${ }^{6}$ suggests as much as $210 \mathrm{~m}(700 \mathrm{ft})$ may be present. In the Mud Spring area these two units appear to be in gradational concact; Hyde and Huttrer ${ }^{7}$ suggest that at least $120 \mathrm{~m}$ ( $400 \mathrm{ft}$ ) of Pioche Shale is present. The regional stratigraphic thickness is $\sim 230 \mathrm{~m}$ (750 ft). Exposures near Mud Spring display abundant small-scale internal folds with generally north-plunging axes; small-scale, low-angle faults are also present. Although the contact between the Pioche Shale and Pole Canyon Limestone is broadly gradational, 
internal deformation suggests that it has been modified by folding and faulting. A predeformation thickness for Pioche Shale could not be determined with confidence.

\section{Conclusions}

Lithologically, the Pioche Shale contains abundant limestone as well as phyllite and slate. Since the unit is clearly metamorphosed, internally highly deformed and not widespread in northern Nye County, it is not considered further in this report.

\section{Dunderberg Shale}

\section{Locations of Mapped Exposures}

The Dunderberg Shale is exposed within the Hot Creek Range (NN-2), and the southern White Pine and Horse Ranges (NN-4). Outcrop areas were examined in the Hot Creek Range near Tybo (NN-2E), Keystone (NN-2F), and Hot Creek (NN-2G), all along the east edge of the topographically rugged range adjacent to Hot Creek Valley. Kleinhampl and $\mathrm{Ziony}{ }^{2}$ mapped three outcrop areas within the southern White Pine-Horse Range area (NN-4); all these exposures are on the west side of the high, rugged range adjacent to the isolated hills of the Horse Camp Basin. ${ }^{8}$ Logistics precluded examination of these areas during this phase of the investigation.

\section{Age and Li thology}

The Dunderberg shale is of Middle to Late. Cambrian age. Where examined in the Hot Creek Range, it consists predominantly of greenishgray to gray, highly micaceous shale and slaty shale that weathers lightgreenish-brown. About $70 \%$ to $90 \%$ of the unit is composed of shale and slaty shale. Interbedded rocks include micaceous limy siltstone, lesser silty limestone, and rare quartzose siltstone. Most interbeds occur as thin discontinuous lenses. Limestone increases in abundance near the base and top of the formation as the unit grades upward into Hales limestone and downward into Swarbrick Formation. North of Keystone (NN-2F), the 
shale is locally metamorphosed to phyllite adjacent to north-trending Tertiary dikes; pervasive silicification and local green copper stain also appear to show a spatial relation to these dikes. In all areas, alteration is most comnon along the western border faults between Dunderberg Shale and younger limestones. This is usually a locally silicified hematitic gouge zone in the shale and silicified breccia in the 1 imestone. Alteration appears to be most pervasive in the most southerly exposures near Tybo (NN-2E).

The Dunderberg Shale exposures described by Moores and others ${ }^{8}$ in the White Pine and Horse Ranges (NN-4) are lithologically similar to those in the Hot Creek Range except that interbedded limestone is present throughout and is proportionally more abundant.

Based on average measured attitudes and surface outcrop width, a thicknesss of $\sim 460 \mathrm{~m}(1500 \mathrm{ft})$ is present near Tybo and $430 \mathrm{~m}$ (1400 ft) north of Keystone. Quinlivan and Rogers ${ }^{9}$ suggest a stratigraphic thickness for Dunderberg Shale on the order of 150 to $180 \mathrm{~m}$ (500 to $600 \mathrm{ft}$ ); the thicknesses near Tybo and Keystone are probably the result of tectonic thickening during thrusting and folding along north-northwest-trending fold axes. Moores and others ${ }^{8}$ report a stratigraphic thickness of $130 \mathrm{~m}$ (430 ft) for Dunderberg Shale in the White Pine-Horse Range region.

\section{Internal Structure}

A11 exposures in the Hot Creek Range show considerable internal deformation. This is reflected in outcrop scale by tight to isoclinal folds within the Dunderberg. The intensity of this deformation is well displayed in excellent exposures of the intensely folded and faulted stratigraphically overlying Hales timestone in the core of a syncline east of Tybo (NN-2E). Internal deformation is also indicated by the wide range in measured attitudes between individual outcrops. Strikes generally range between $N 45^{\circ} \mathrm{E}$ and $N 45^{\circ} \mathrm{W}$; dips vary greatly but are generally between moderate to the west and steep to the east. 
Though not examined, a wide variation in thickness of Dunderberg Shale and equivalent strata in the southern White Pine and Grant Ranges is reported by Cebul1, ${ }^{6}$ Hyde and Huttrer, ${ }^{7}$ and Moores and others ${ }^{8}$ over relatively short distances. In addition, all authors briefly mention the presence of varying types of internal deformation including folds, faults, and local metamorphism to phyllite. All suggest the likelihood of tectonic thickening and/or thinning of the unit in this region.

\section{Structural Setting}

In the Hot Creek Range, Dunderberg Shale exposures are found along the faulted east margin of the range. Exposed Paleozoic strata generally decrease in age and dip moderately to the west, and the western portion of the range is underlain by Tertiary volcanics and related sediments. Though local variations are common, the overall pattern is a west-tilted fault block. The eastern border fault is probably the structurally highest of a series of synthetic step faults buried beneath Hot Creek Valley. Faults within the range that separate major stratigraphic units also tend to strike north and form a series of north-trending horsts and grabens. In this part of the range, thrust faults are subordinate to high-angle faults, and most thrusts mapped by Quinlivan and Rogers ${ }^{9}$ are inferred to be of Tertiary and Quaternary age; these are mainly younger than those high-angle faults they occasionally overlap. Thrust faults are more common in middle and late Paleozoic strata both north and south of this area. Two observations strongly suggest recent tectonic activity: Faults cutting Quaternary alluvium have been mapped by Kleinhampl and $\mathrm{Ziony}{ }^{2}$ and Quinlivan and Rogers ${ }^{9}$ along the eastern margin of the Hot Creek Range and within Hot Creek Valley. Also, Hot Creek is a major east-flowing, superposed stream that traverses the entire range in a canyon as much as $150 \mathrm{~m}$ (500 ft) deep.

The structure of the White Pine, Horse, and Northern Grant Ranges is characterized by north-striking east-dipping (occasionally overturned to the west), gently folded sequences of Paleozoic strata. These sequences are cut by east-northeast-striking high-angle faults and variably deve1oped low-angle faults that usually juxtapose younger over older strata. 
Tertiary age of thrusting (or gravity sliding) suggests a relation to regional extension in Miocene time. The structural axes of the White PineHorse Ranges show $\sim 2400 \mathrm{~m}$ (8000 ft) of horizontal separation across the west-northwest-striking Currant Summit fault zone. 8

Faults cutting Quaternary alluvium are present along the west margin of the White Pine and Grant Ranges. This faulting and the generally eastward tilt of the range suggest block uplift in latest Tertiary and Quaternary time, and possibly Holocene time.

\section{Subsurface Projections}

In the Hot Creek Range, Dunderberg Shale is mostly bounded by highangle faults. The eastern border juxtaposes. Tertiary volcanic rocks and Cambrian strata; the thickness of the intervening stratigraphic section implies a depth of at least $3000 \mathrm{~m}(10000 \mathrm{ft})$ to Dunderberg Shale along the eastern range margin. The western boundary is not faulted near Tybo; the boundary is faulted between Keystone and Hot Creek where depth to Dunderberg Shale is between $750 \mathrm{~m}(2500 \mathrm{ft})$ and $1950 \mathrm{~m}(6500 \mathrm{ft})$, generally increasing to'the north. The eastern boundary everywhere lies in rugged mountainous terrain traversed by steep east-draining canyons (from south to north, Tybo, Empire, Keystone, 01d Dominion, and Hot Creek).

Near the White Pine-Horse Range exposures, Moores and others ${ }^{8}$ suggest several tens of thousand feet of throw on the Ragged Ridge fault bordering the east margin of the Horse Camp Basin. Thus, Dunderberg Shale can be expected to be present at a depth of $\sim 3000 \mathrm{~m}(10000 \mathrm{ft})$. This suggests that occurrence of Dunderberg Shale in the subsurface at mineable depths outside the ranges is unlikely. 
Mineral Resource Activity, Land Use, and Springs

The presently inactive Tybo area contains numerous shafts and adits along the western Dunderberg Shale boundary, and extensive underground workings. ${ }^{10}$ A newly reopened base metal-gold mining operation is present at Keystone. Most production comes from mineralized faults and veins within Ordovician limestones, usually where faulted against Dunderberg Shale.

Although there is no present mining activity in the White Pine-Horse Range area, much of the Currant Summit area (north and south of US Highway 6) in the northern Horse Range has recently been staked. Mines of the Currant Creek district west of Currant Summit have historically produced some silver and gold. 11 Active petroleum exploration is ongoing in Railroad Valley west of the Grant and White Pine Ranges, and the Trap Springs oil field (west of Currant along US 6) now has more than a dozen producing wells. Only one pumping well was observed at the Eagle Springs Field $16 \mathrm{~km}$ $(10 \mathrm{mi})$ southwest of Currant.

Cattle grazing is the dominant 1 and use in all areas examined. Alfalfa is grown for feed along Hot Creek and along Currant Creek in the Horse Camp Basin.

Hot Creek, a major perennial stream, is fed by numerous springs within the Dunderberg Shale exposure area. The spring west of Keystone supplies water for mining operations and flows strongly at the surface. Numerous small springs feed Tybo Creek from near the Dunderberg ShaleHales Limestone contact.

\section{Conclusions}

Overa11, Dunderberg Shale in northern Nye County does not meet the working guidelines outlined above: it has complex internal structure, current and historic mining and prospecting activity, occurs in close proximity to recent faulting and rapid uplift, and has unfavorable subsurface projections (i.e., $\backsim 600 \mathrm{~m}$ [3000 ft] depth) into topographically low areas adjacent to exposures in the ranges. 
Palmetto Formation and Equivalent Strata (Toquima Range)

\section{Locations of Mapped Exposures}

Seven areas underlain by Palmetto Formation were examined at widely spaced locations in the southern part of the Toquima Range. This is the dominant sedimentary rock unit in the range, and although parts of all areas mapped by Kleinhampl and $\mathrm{Ziony}{ }^{2}$ were examined, these areas are only a very small fraction of the area underlain by these strata. All strata examined are within NN-1, Part A of Simpson and others. 1 There are no argillaceous rocks present in NN-1 Part B. The Palmetto Formation was defined by Ferguson and Cathcart ${ }^{12}$ to include all strata above the Gold Hill Formation and below late Paleozoic clastic strata on the west side of the Toquima Range. As defined by Ferguson ${ }^{13}$ in the Manhattan district, the unit includes in ascending order the Mayflower Schist, Zanzibar Limestone, and Toquima Formation. These and equivalent strata were mapped by Kleinhampl and $\mathrm{Ziony}^{2}$ as Ordovician and Cambrian Shales and Limestones (OCs1); the designation "Palmetto Formation" is used here largely for convenience.

Age and Lithology

The Palmetto Formation ranges in age from Late Cambrian (?) to Late Ordovician; graptolites present near Mt Moriah suggest an Ordovician age for the unit southwest of Manhattan. The upper part of the unit is probably a metamnrphosed equivalent of the Pogonip Group that is exposed extensively in the northern part of the Toquima Range ${ }^{14}$ and in many ranges to the east. 2

Dominant rock types in the Palmetto Formation are phyllite, spotted (cordierite?) phyllite, and slate. Phyllite is generally dominant in western exposures and slate in the east, but this may be related to the proximity to granitic intrusions in areas examined in the west. Phyllite and slate are estimated to make up $-50 \%$ of the unit at most areas examined. Interbedded rock types include silicified and recrystallized quartzite, recrystallized bluish-gray limestone, and calcareous slate. 
Most interbeds are thin and continuous on outcrop scale; rhythmic, thinbedded phyllite, slate, and calcareous slate characterize exposures near Round Mountain (NN-1F) and Manhattan (NN-1A). Quartzites are usually thinbedded, but a lens of quartzite $60 \mathrm{~m}$ (200 ft) thick was observed east of Manhattan. Quartz veins and veinlets are common and most abundant near the Manhattan and Round mining districts.

Foliation development in any one area appears closely related to composition. The most phyllitic strata are probably those whose original clay content was high.

Obvious pervasive alteration is uncommon in phyllites and slates. Most alteration within phyllite appears to be related to quartz veinlets that are commonly oxidized and show reddish- to yellowish-brown stain. This alteration is probably related to postmetamorphic permeability, as suggested by frequent association of quartz veins and oxidized zones with. smal1-scale faults and contacts between contrasting lithologies. Although most rock types are not pervasively altered, quartzite lenses are invariably highly recrystallized and cut by numerous quartz-filled fractures.

Thickness is difficult to estimate because of intense internal deformation. Ferguson and Cathcart ${ }^{12}$ noted a thickness of $1500 \mathrm{~m}(5000 \mathrm{ft})$ of Palmetto Formation, but suggested that some of that thickness is. probably caused by unrecognized isoclinal folding while noting the fact that the base and top of the unit are not exposed in any contiguous areas.

Wherever bedrock is exposed, the Palmetto Formation shows considerable outcrop-scale deformation. Folds are usually close to isoclinal and gently plunging. Fold axes generally trend northwest in the Manhat an area and southwest in the Round Mountain area. Axial surfaces mostly dip gently west with individual folds commonly overturned to the east. Boudinage quartz veins in the Manhattan area (NN-1A, NN-1B) often show a long axis subparallel to fold axes. 
Faulting appears subordinate to folding but is clearly significant in most areas. Along east Manhattan Wash (NN-1C), a large fault-bounded quartzite lens shows no internal folding but has an attitude markedly discordant to adjacent highly folded phyllites. This probably results from the differential response of the two contrasting lithologies to deforming stresses. Along roadcuts north of the Mt Moriah Cemetery west of Manhat (NN-1B), numerous smal1-scale faults are exposed in highly folded phyllite. Although orientations vary, most of these faults tend to dip gently or moderately to the southwest and northeast. The low dip of faults and axial surfaces suggests a genetic relation to thrusting and probable tectonic thickening of the sequence.

\section{Structural Setting}

A11 locales examined are in the southern Toquima Range. The predominant rock types underlying the range are lower Paleozoic metamorphosed sediments (largely the Palmetto Formation), granitic plutons of Late Cretaceous age, and tuffs and flows of Oligocene to Miocene age. Rare discontinuous lenses of coarse clastic rocks of Pennsylvanian (?) age and a Pliocene (?) rhyolitic tuff-flow unit north of Manhattan ${ }^{2}$ are present.

The lower Paleozoic rocks have been folded along west-northwesttrending, subhorizontal axes and thrust generally to the northeast as shown by overturned folds near Manhattan. 213 Metamorphism to greenschist and/or amphibolite facies appears to have been synkinematic with this folding and followed by a hydrothermal event, producing alteration along permeable fractures and local breakdown of earlier porphyroblasts. Mineralization in the Manhattan district appears to be largely related to this second event. 13

The metasediments have been intruded by plutonic masses that range in composition from granite to quartz monzonite, Radiometric $\mathrm{K}$-Ar dates of various portions of the pluton west of Belmont all yield Late Cretaceous ages. ${ }^{15}$ Tertiary volcanic rocks unconformably overlie all older rocks and, although found throughout the range, are particularly abundant north of Manhattan and underlying Mt Jofferson, the highest peak in the range. 
The fact that the K-Ar "clocks" in the plutonic rocks have not been "reset by younger volcanism suggests that a major regional increase in thermal gradients did not accompany volcanism in the Toquima Range.

High-angle faults clearly cut earlier thrusts in many parts of the range. Although incompletely mapped by Kleinhampl and $\mathrm{Ziony},{ }^{2}$ these faults tend to show a dominant north-northeast strike parallel to the range margins, and a subordinate north-northwest strike. The east margin of the range is marked by a normal fault and is well exposed for several miles north and south of Belmont. Kleinhampl and 2 iony ${ }^{2}$ show several faults that cut Quaternary alluvium along the eastern margin of the range, but we did not examine them. The west margin of the range shows little evidence of recent faulting. The eastern part of the range is marked by rugged topography and deeply incised canyons, while the west side topography is more subdued, suggesting a major component of westward tilting accompanying uplift. Ferguson and Cathcart ${ }^{12}$ suggest that most of the uplift probably occurred in late P1iocene to early Pleistocene time.

\section{Subsurface Projections}

The absence of clear evidence for faulting on the west margin of the Toquima Range suggests that the Palmetto Formation may underlie Quaternary alluvium and pediment gravels for several miles west of the range front south of Round Mountain. The formation is also mapped underlying the low hills southwest of Manhattan. In most other exposure areas, topography is fairly rugged and mountainous.

Much of the range is underlain by granitic plutons, and depth of surface outcrops of Palmetto Formation may be 1 imited by granitic masses at shallow depth.

The Monarch area (NN-1D) lies on the low saddle between the Toquima and Monitor Ranges, and Palmetto Formation may underlie several square miles, although it is very poorly exposed at the surface. 
Mineral Resource Activity, Land Use, and Springs

A1l the Palmetto Formation locales are close to presently or historically active mining districts. Manhattan presently has three active mines (two underground, one surface) and has produced gold, silver, and tin ores.11 In the Manhattan area, much of the Palmetto Formation outcrop contains literally hundreds of abandoned shafts, adits, and prospect pits. The largest active operation in the range is a surface mine and mill at Round Mountain, where gold is produced from a Tertiary rhyolite stock. Some earlier production came from the contact zone between rhyolite dikes and the Palmetto Formation north of Mariposa Canyon (NN-1E). The Belmont district has been largely inactive since 1900, but Payne and Papke 16 indicate one active silver mine at Barcelona, several miles northwest of the town of Belmont. Some recently staked claims were noted in the Jefferson summit area between Meadow Canyon (NN-1E) and Jefferson Canyon $(\mathrm{NN}-1 \mathrm{~F})$; the claims are located entirely within Tertiary volcanic rocks.

The only other land use besides mining is cattle grazing and related activities. Alfalfa is grown on irrigated land on the west side of Big Smoky Valley at the foot of the Toiyabe Range.

Springs are concentrated along the east side of the range and appear closely related to faulting along the margin of the range. Several strcamo, inrluting Jefferson, Belmont, and Meadow Canyon Creeks, appear to run for most of the year along at least part of their courses. Eastdraining canyons often contain dense grassy vegetation suggestive of abundant subsurface water.

\section{Conclusions}

Although the Palmetto Formation in places meets the working guidelines in terms of thickness, areal extent of exposures, and subsurface projections (along the west margin of the range), it is not considered here further because of intense internal deformation, metamorphism, and mining activity. 
The intensity of internal deformation, including tight-to-isoclinal folding on both large- and small-scale and metamorphism to amphibolite grade, introduces uncertainties into any predictions of permeability. Intensity of mining activity near Manhattan (where the most favorable subsurface projects are) is undesirable in the present context, and future mining activity is anticipated.

Pogonip Group

\section{Locations of Mapped Exposures}

Three sites underlain by strata assigned to the Pogonip Group were examined. Two are in the southern Grant Range-Quinn Canyon Range area (NN$6 C, N N-6 D)$, and one is in the southern part of the Horse Range $(N N-4 B)$. The Pogonip Group is widespread throughout northern Nye County, but on ly in the White Pine, Horse, and Grant Ranges do argillaceous units have a reported thickness $>150 \mathrm{~m}$ (500 ft). ${ }^{1}$ Sites examined all lie on the margins of mountainous areas. In the areas considered, a total of 16 exposure areas have been mapped by Kleinhampl and Ziony. ${ }^{2}$

Age and Lithology

The Pogonip Group is Lower to Middle Ordovician and is generally divided into three formations that are called by various names but are invariably a lower limestone formation, a middle shale and limestone formation, and an upper limestone formation. The middle formation, usually referred to as the Ninemile Formation, is the argillaceous unit of concern here. The Stoneberger Shale $\mathrm{e}^{14}$ is not present here, as has been suggested by Simpson and others. 1

In all areas examined, the Pogonip Group is exposed beneath the distinctive ledge-forming, white Eureka Quartzite. In only one area (NN6D) was a distinctive argillaceous horizon found. This exposure is an isolated monadnock in the mouth of $0 x$ Spring Wash in a large topographic embayment on the west edge of the southern Grant Range. The argillaceous horizon occurs $\sim 460 \mathrm{~m}$ ( $1500 \mathrm{ft}$ ) below the Eureka Quartizite and is $60 \mathrm{~m}$ 
(200 ft) thick. Gray to grayish-green shale and siltstone make up about $40 \%$ of the unit. The rest is composed of bioclastic, gray-to-brown limestone that occurs as discontinuous lenses and is locally fossiliferous. Abundant well-preserved Receptaculites species occur throughout. The Horse Range locale (NN-4B) contains no exposed shale but has only a partial, $460 \mathrm{~m}(1500 \mathrm{ft})$ section of upper limestone adjacent to a north-striking fault contact with Tertiary (?) alluvial gravels. The thalde Ranch area along Cherry Creek in the Quinn Canyon Range contains what has been mapped as an almost complete Pogonip section. ${ }^{2} 17$ Here Cherry Creek has cut a steep, locally almost vertical walled canyon through a broad anticline developed in Pogonip strata. Limestone dominates all exposures observed and, although shaly interbeds are locally common, shale does not appear to make up a significant part of any particular horizon.

\section{Internal Structure}

The steep canyon walls near thalde Ranch expose small-scale open-totight folds that generally parallel the north-northwest trend of the major mapped fold. In the other areas, the limestones are highly fractured and contain calcite veinlets, but the Eureka Quartzite-Pogonip sequences appear largely homoclinal and not internally folded; dips observed are everywhere greater than $40^{\circ}$.

Conclusion

The Ninemile Formation of the Pogonip Group does not appear to contain noncalcareous argillaceous strata of sufficient thickness and is not considered further in this report.

\section{Chainman Shale and Equivalent Strata}

\section{Locations of Mapped Exposures}

The Chainman Shale and equivalent strata, including the Eleana and Diamond Peak Formations, are the most extensively exposed argillaceous rock units in northern Nye County. The greatest area of exposure is in the Pancake Range (NN-3), but these rocks also crop out at several locales in 
the Hot Creek, White Pine, Horse, and Grant Ranges and in the low hills on the flanks of the White River Valley. Seventeen locales were examined by the authors out of about 35 areas shown by Kleinhampl and $\mathrm{Ziony}{ }^{2}$ Four areas within the Pancake Range locale (NN-3) were mapped, two at a scale of $1: 24,000$ (Figures 2 and 3 ) and two at a scale of $1: 62,500$ (Figures 4 and 5). One partial section of $210 \mathrm{~m}$ (700 ft) was measured north of Duckwater Peak (NN-3E) and an accurate thickness of a partial section was determined by mapping at Portugese Spring (NN-3B); measureable sections with abundant shale are rare because of extreme ease of erosion of the shales relative to other rock types. Most shale tends to be covered by a mantle of sandstone, limestone, or volcanic float and most outcrops had to be examined with the help of a shovel. Where topographic coverage is available, measured attitudes were plotted on maps to aid in thickness estimation. Estimates of proportions of different rock types are based on ground traverses within the exposure areas; poor quality of most exposures makes these estimates prone to error.

Age and Lithology

Within northern Nye County, the Chainman Shale and equivalent rocks are probably all Upper Mississippian, although the more western and southerly facies of the Eleana Formation probably includes some Lower Mississippian strata. 1819

Proportions of lithologic types composing Chainman Shale appear to vary considerably from west to east and to a lesser extent from north to south (Table 2). In the Pancake Range and most areas to the east, the dominant rock exposed is dark-gray to black shale and clayey siltstone that is locally rich in organic material. Subordinate rock types include fine-grained quartzose sandstone and siltstone and relatively rare limestone. Sandstone generally increases in abundance to the west, both within and between the ranges, and sandstone appears to dominate the Eleana Formation exposed in the Hot Creek Range. To the east, sandstone interbeds in shale tend to become thinner, finer grained, and less abundant. There appears to be a slight proportional increase in sandstone to the south, but this may be more because of a regional change in exposed stratigraphic level than because of any significant regional variation. 
Lithologic Summary of Chainman Shale and Eleana Formation, Northern Nye County, Nevada*

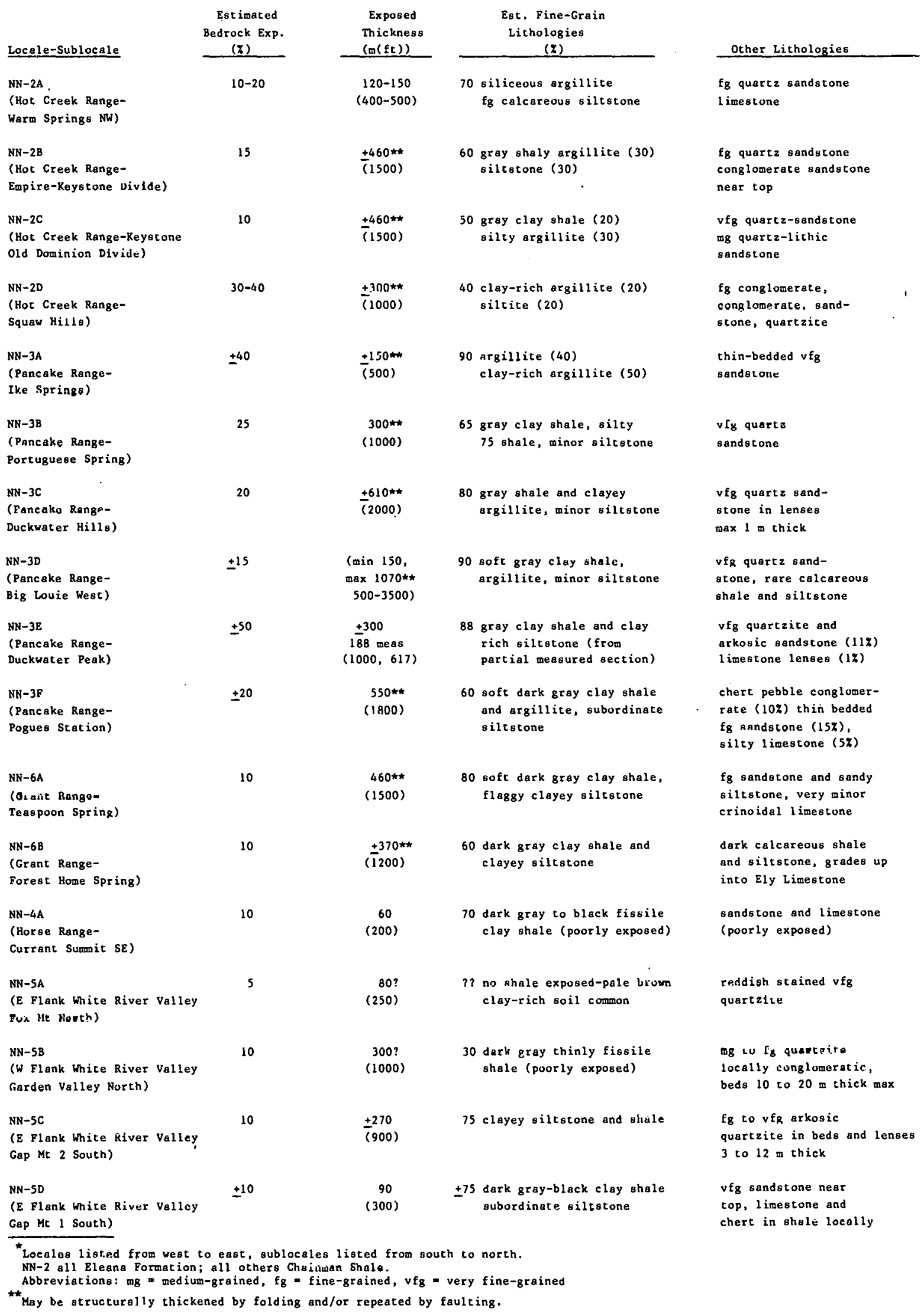


Figure 2

Geologic Map of the Portugese Spring Area $(\mathrm{NN}-3 \mathrm{~B})$, Nye County, Nevada

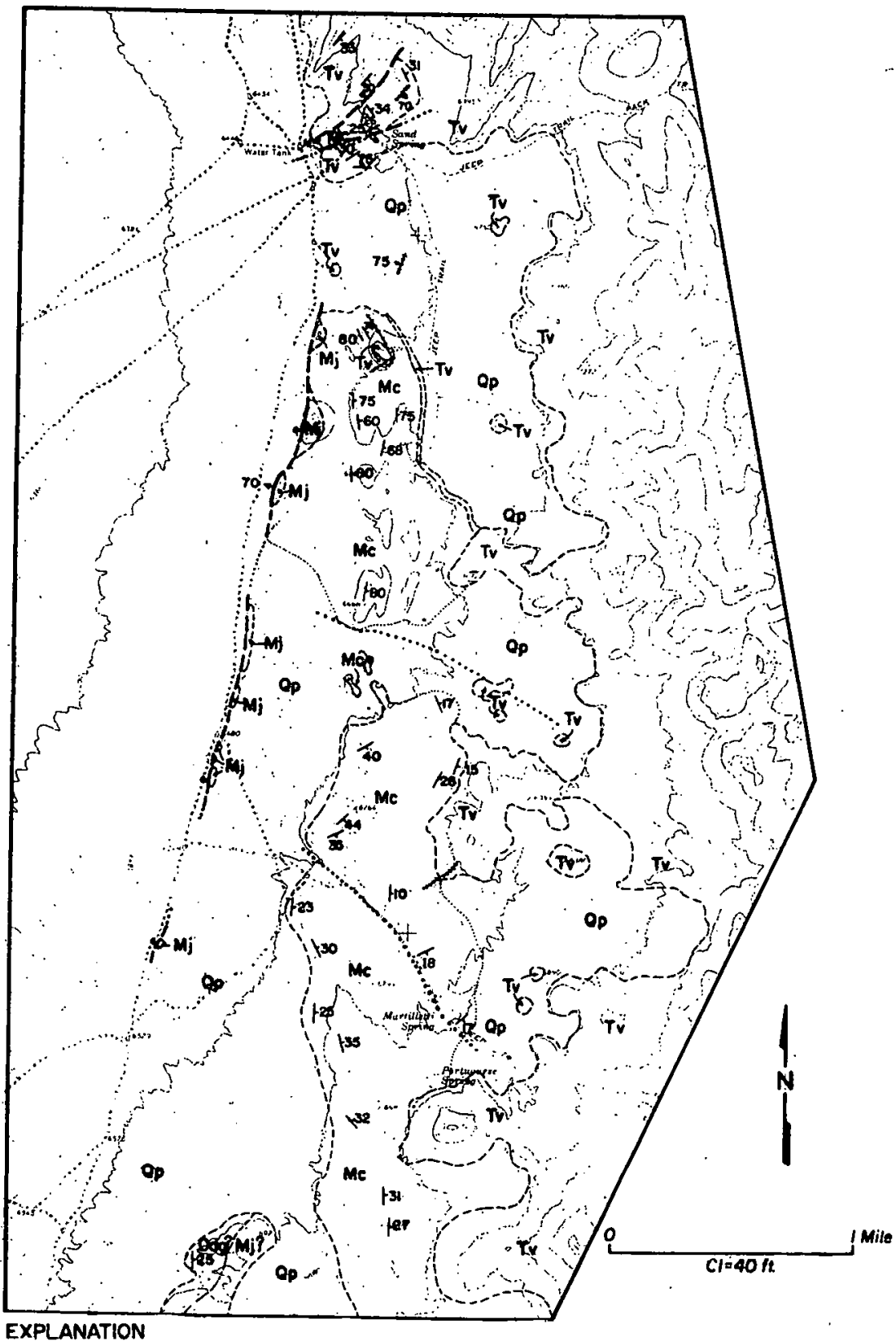

EXPLANATION

YSTRIKE AND DIP OF BEDDING

70 HIGH ANGLE FAULT, SHOWING DIP BALL AND BAR ON DOWNTHROWN SIDE (DASHED WHERE INFERRED. DOTTED WHERE CONCEALED) 30 STRIKE AND DIP OF PLANAR STRUCCONCEALED)

\section{Qp PEDIMENT of mop.}

Tv bedded tuffaceous sediments.

DIKES, mostly silicic.

MC CHAINMAN SHALE: predominontly fissile, dork-gray to block, non-calcareous shole and silty shale. Subordinate very thin bedded, fine-grained. quarizite and siltstone. Rore discontinuous quartzite lenses up to $2 \mathrm{~m}$ thick.

Mi JOANNA LIMESTONE: gray limestone, mostly highly froctured and locally crinoid-rich. Weathers yellowish gray. Local calcareous siltstone horizons near contact with Chainman Shale.

Ddg DEVLS GATE LIMESTONE: thinly to medium-bedded, dark-groy, locally dolomitic limestone. Locally rich in solitary horn corals. 


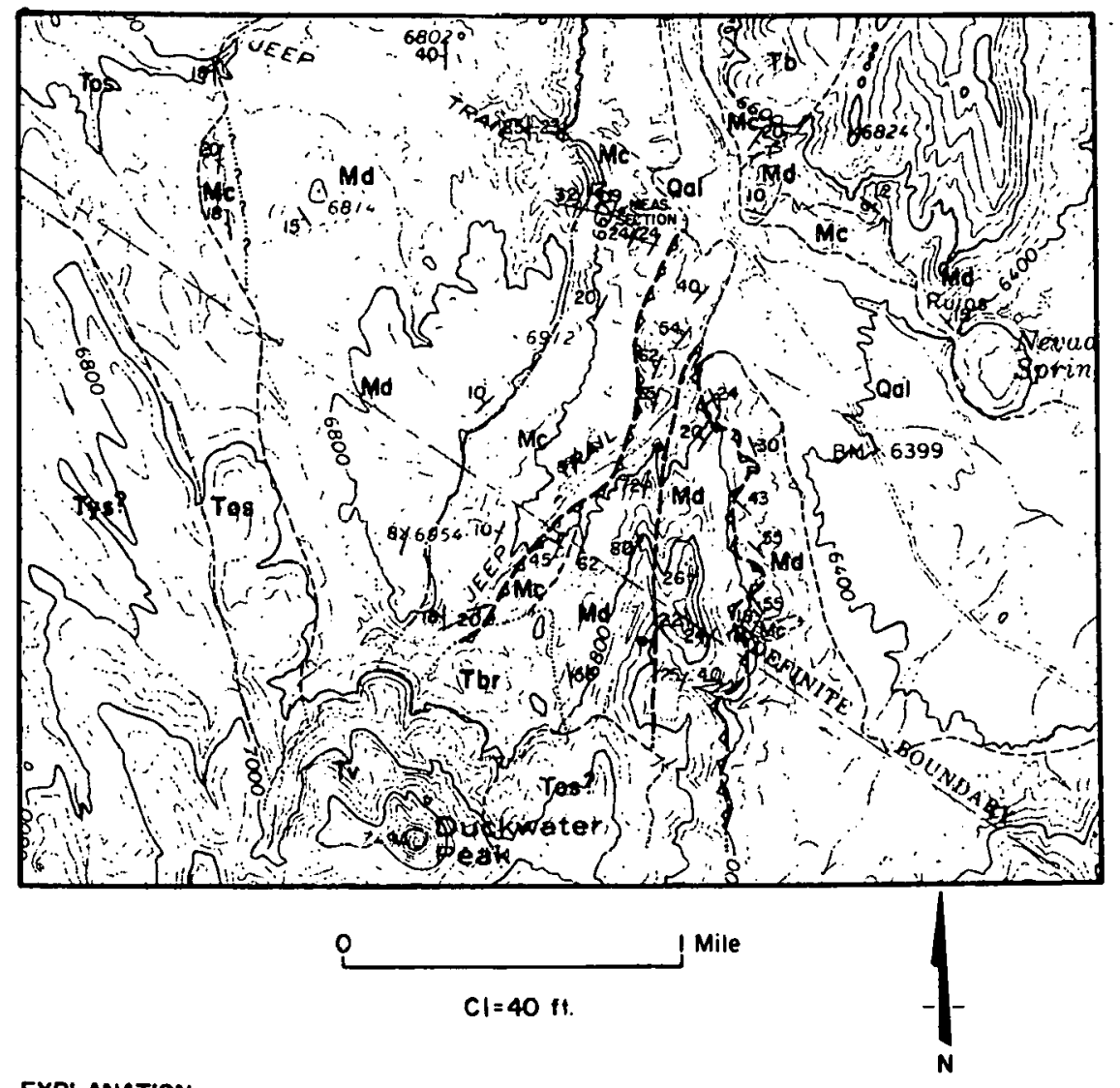

EXPLANATION

Y STRIKE AND DIP OF BEDDING

$\checkmark$ SEDIMENTARY CONTACT CDOTTED WHERE CONCEALEDI 8od STRIKE AND DIP OF OVERTURNED

d HIGH-ANGLE FAULT, BALL AND BAR ON DOWNTHROWN SIDE (DOTTED $\nabla$ LOW-ANGLE FAULT OF PROBABLE WHERE CONCEALED)

Y GRADATIONAL SEDIMENTARY , CONTACT

$\checkmark$ MID-TERTIARY AGE (DOTTED WHERE CONCEALED)

Figure 3

Geologic Map of Duckwater Peak Area $(\mathrm{NN}-3 \mathrm{E})$, Nye and

[a] ALLUVIUM; includes some colluvium covering bedrock. White Pine Counties, Nevada

Tb BASALT FLOW TYS YOUNGER TERTIARY SEDIMENTS and VOLCANICS: interbedded tuffoceous sand-
stones, siltstones with minor tuff and basalt flows.

ANGULAR UNCONFORMITYM

TV INTERMEDIATE TO SILICIC VOLCANICS: includes reloted shallow intrusives. Underlie

Tos OLDER TERTIARY SEDIMENTS: interbedded fluvial-alluvial quorizose and fuffaceous

sondstone and minor felsic tuff; silicified and breccioled near Duckwater Peak.

Tbr METEROLITHOLOGIC BRECCIA: large blocks of Poleceoic limestone, sondstone and conglomerate which differ greally in attitude. Aye uncertain but may be related to grovity-slide foulting ond/or volconic octivity; locally silicified.

UNCONFORMITY

DIAMOND PEAK FORMATION: interbedded fine-to coorse-grained quartzose sandstone and graywacke with locai chert puble ond cobble conglomerote subnrtinnte Shale.

MC CHAINMAN SHALE: dork-gray, fissile shale and clayey siltstone with fine-to mediumgrninad thin sondstone interbeds, very minor thin silty limestone interbeds; approxi-
mately $800 \mathrm{ft}$ exposed. 
R.56E.

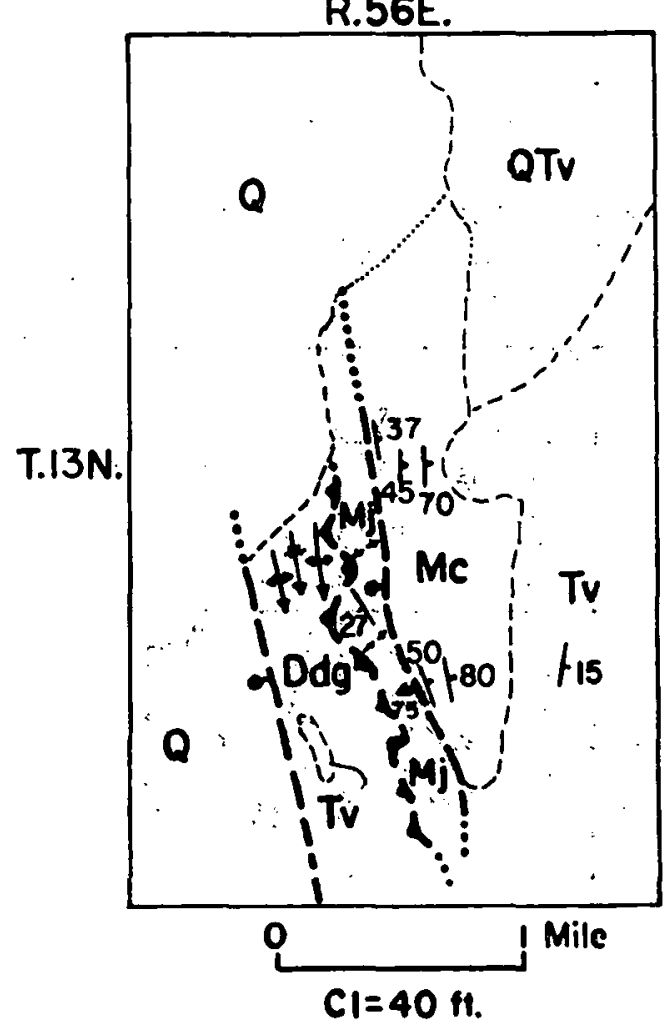

EXPLANATION

- HIGH-ANGLE FAULT, BALL AND THRUST FAULT, TEETH ON

$Y^{40}$ STRIKE AND DIP OF BEDOING * SYNCLINE, SHOWING PUNGE $\gtrsim$ ANTICLINE, SHOWING PLUNGE

a. PEDIMENT, ALLUVIUM

OT. YOUNGER BASALTIC VOLCANICS

[M chanman shale

Mi] JoANMA LIMESTONE

TV ODER SILICIC TO INTERMEDATE

DIKES

Figure 4. Geologic Sketch Map of Duckwater Hills, Nye County, Nevada

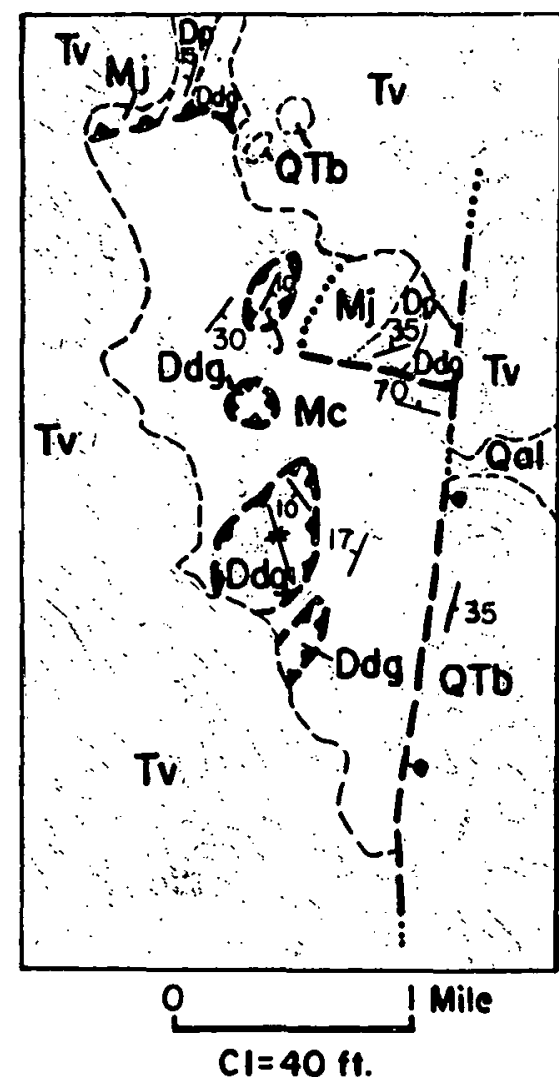

EXPLANATION

7. HIGH-ANGL FAULT. BALL AND BAR ON DOWNTHROWN SIDE

TMRUST Fanlt, TEETh on

UPPER PLATE.

al ALLUVIUM

Mj] JOANNA LIMESTONE

OTI VOUNGER BASALTIC VOLCANICS DD PILOT SHALE

TV OLDER SILICC TO INTERMEDIATE DO DEVILS GATE LIMESTONE VOLCANIC

M. ChaMmean SHALE

Figure 5. Geologic Sketch Map of Big Louie West Area (NN-3D), Pancake Range, Nye County, Nevada 
The sequence of rocks in Mississippian time in east-central Nevada probably represents foreland basin flysch-type deposits shed eastward from an Antler orogenic upland in central and western Nevada. ${ }^{18} 19$ In northern Nye County the Chainman Shale is commonly composed of interbedded clay shales and clay-rich siltstones and fine-grained sandstones, suggesting an intertonguing of distal turbidites of a system of submarine fan deposits with hemipelagic muds in the eastern portion of the flysch basin (Figure 6).

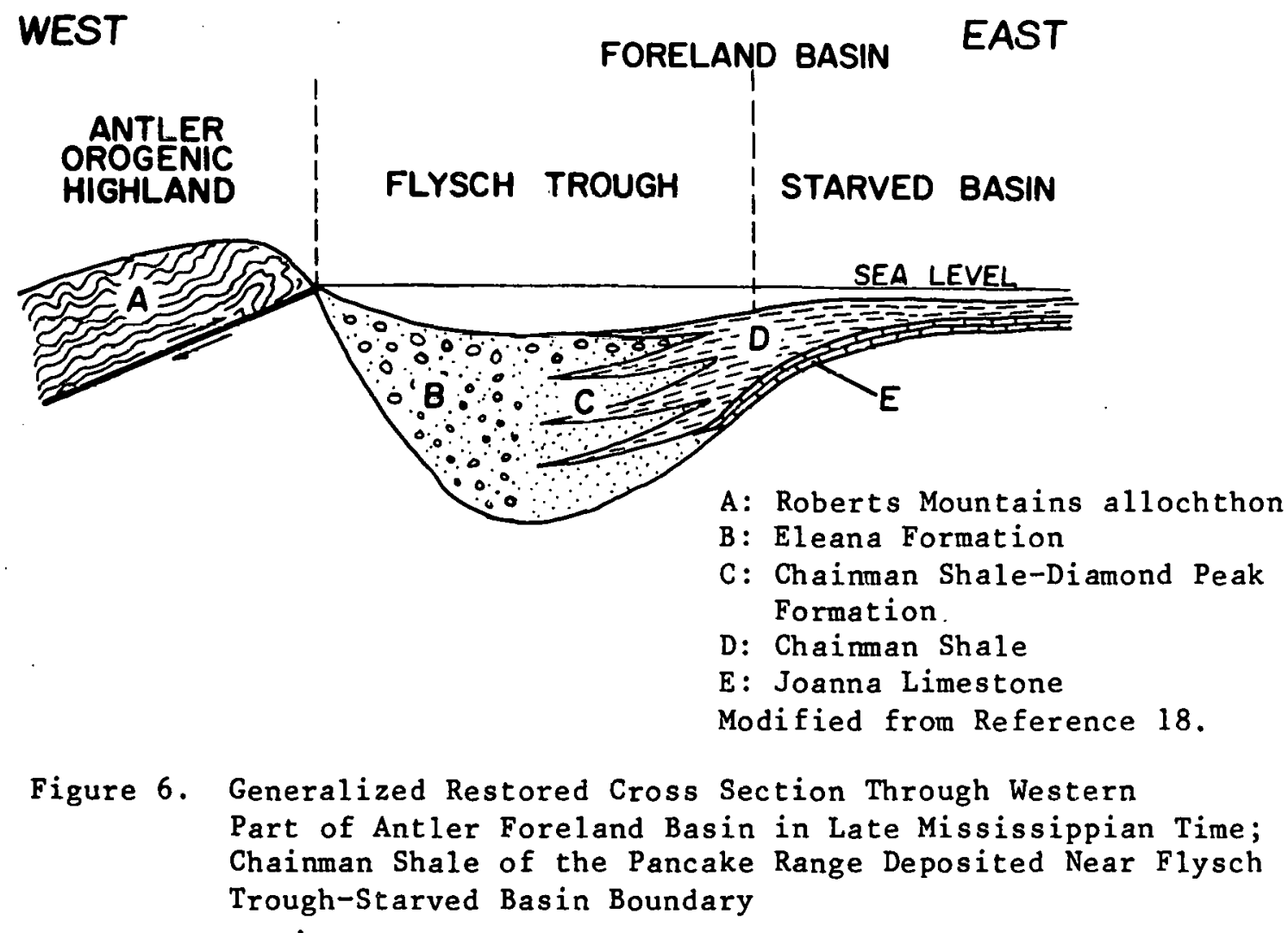

In the White River Valley (NN-5), the Grant (NN-6) and Horse Range $(\mathrm{NN}-4)$ locales, the Chainman shale is overlain comformably and gradationally by Ely Limestone. In the southern Pancake Range (NN-3) and in parts of all other areas examined, Chainman Shale is unconformably overlain by Tertiary volcanic and volcaniclastic rocks. In the northern 
Pancake Range, the Chaimman Shale grades upward and interfingers with the sandstones, gray-wackes, and conglomerates of the Diamond Peak Formation. Farther north in White Pine County, the Ely Limestone overlies Diamond Peak Formation with a gradational contact. 20

In the Pancake Range and all areas to the east, the Chainman Shale is locally underlain by the crinoidal Joanna Limestone. In most areas, however, Joanna Limestone or some older rock unit is in fault contact with Chainman Shale and the base of the unit is not exposed. In the Hot Creek Range, Eleana Formation unconformably (?) overlies limestories of the Nevada Formation (Devonian).

Nowhere was a complete stratigraphic section of Chainman Shale found exposed, so all thicknesses estimated in Table 2 are minimum. As noted, several of the thicknesses estimated are probably tectonic in that unexposed faulting and folding may have repeated and/or thickened the sequence.

Pervasive alteration appears minimal in most Chainman-Eleana exposures examined. Only four locations showed any visible alteration, and these were restricted areas of oxidation and silicification adjacent to shallow Tertiary dikes and overlying volcanic rocks. Faults bordering exposure areas, particularly those near extensive volcanic terrains, are often marked by brecciated, red-stained, and silicified limestones. Shales are generally unaltered except within a few feet from these faults.

\section{Internal Structure}

In most areas examined, $\dot{a}$ wide variation in measured attitudes within the Chainman-Eleana exposures suggests the presence of considerable internal deformation. Exposures were not good enough in most cases to determine whether folding or faulting was dominant, but in view of the strong tendency for clay-rich shales to deform by flow, even at shallow depth, ${ }^{21}$ folding would be expected to predominate. In the Portuguese 
Spring area (NN-3B); Figures 2, 7) where folding is minimal, Chainman Shale is broken into three homoclinal blocks by inferred west-northweststriking faults.

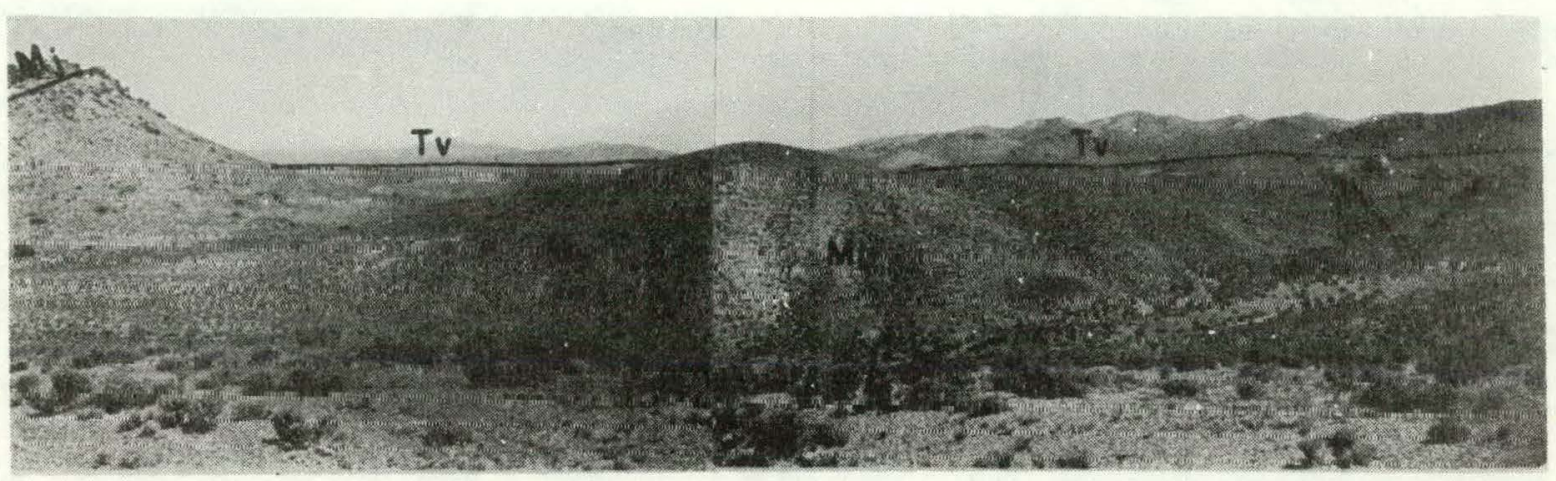

Figure 7. Chainman Shale Exposed in Portuguese Spring Area, Pancake Range (NN-3B) (View is north approximately parallel to strike; dip is $75^{\circ}$ to $80^{\circ}$ east. See Figure 2 for symbols.)

Nowhere was flat-lying Chainman Shale or Eleana Formation found. The strata exposed in all areas are tilted at least $10^{\circ}$ and as much as $85^{\circ}$, even in areas where measured attitudes show relatively little variation (NN-3B, Figure 7; NN-3E).

\section{Structural Setting}

Chainman Shale is exposed in several ranges in northern Nye County. Since these ranges have distinctive structural features, they are discussed individually below. The Eleana Formation is exposed at several locales in the Hot Creek Range but it is not considered further here because of the high percentage of interbedded sandstones. A brief discussion of the structure of the Hot Creek Range is included in the section on Dunderberg Shale. 
Pancake Range (NN-3)--Chainman Shale is exposed in the central and northern Pancake Range, which is nearly $160 \mathrm{~km}$ (100 mi) 1ong, 8 to $32 \mathrm{~km}$ ( 5 to $20 \mathrm{mi}$ ) wide, and elongate in a $N 20^{\circ} \mathrm{E}$ direction. The range widens north of Portuguese Mountain, where the Duckwater Valley separates the main portion of the range on the west from the Duckwater Hills on the east. Hot Creek Valley and Big Sand Springs Valley bound the east side. Most summit elevations in the range are $<2400 \mathrm{~m}(8000 \mathrm{ft})$, with Portuguese Mountain the most notable exception in the center of the range with an elevation of $2818 \mathrm{~m}$ (9240 ft).

Volcanic and volcaniclastic rocks of Tertiary age underlie most of the central and northern Pancake Range, Exposed sedimentary rocks are mostly middle to late Paleozoic in age, but include some Late Cretaceous (?) and early Tertiary (?) strata. ${ }^{2}$ Pre-Tertiary strata are most extensively exposed for about $24 \mathrm{~km}$ ( $15 \mathrm{mi}$ ) north and south of Portuguese Mountain in the central part of the range.

Thrust faults are exposed in all areas underlain by Paleozoic strata. Most prominent is Portuguese Mountain, which is apparently a major thrust fault with Devonian and Mississippian strata in the upper plate and Mississippian Chainman Shale and Joanna Limestone in the lower plate. Most thrusts mapped ${ }^{2}$ place older strata over younger and are clearly truncated by Tertiary volcanic rocks. If Cretaceous and earliest Tertiary strata are involved in thrusting, as suggested by Kleinhampl and Ziony, ${ }^{15}$ an early Tertiary (Laramide) age of faulting is indicated. Sma11- and 1arge-scale faults are overturned to the east, suggestive of eastward tectonic transport. An exception to this generalization occurs in the northernmost areas (NN-3E, NN-3F), where coarse conglomerate of the Diamond Peak Formation is faulted over stratigraphically underlying Chainman Shale. In this area, "older" Tertiary sediments and Paleozoic rocks are both tilted gently west and overlain by relatively flat-lying "younger" Tertiary volcanic and sedimentary strata. The local occurrence of these low-angle faults suggests that they are largely gravity-slide faults of middle to late Tertiary age. 
The central part of the range has been uplifted and tilted east along north-northeast-striking normal faults that locally cut Quaternary alluvium in Big Sand Springs Valley. ${ }^{2}$ Mapping of range-marginal structures is incomplete in volcanic rocks, but the linear, abrupt western margin strongly suggests fault control at least as far south as US Highway 6 . The east margin of the range is generally not marked by we11-defined faults.

The northern part of the range is segmented by faulting east to west into the Duckwater Hills, Duckwater Valley, and Moody Mountains. The Moody Mountains are underlain by volcanic rocks through which local inliers have been eroded, exposing Paleozoic rocks. The block appears to be faultbounded on both east and west sides. The Duckwater Hills are largely volcanic and marked by a well-defined fault on the west margin adjacent to Duckwater Valley. All the major bounding faults strike north to northnorthwest and are down on the west.

High-angle faults within the ranges occur chiefly within areas underlain by Paleozoic rocks and generally form two sets: one has a north-tonortheast strike and the other has an east-to-southeast strike. Offsets along these faults vary, as do the attitudes of blocks between them. In general, areas near Portuguese Mountain (NN-3A, NN-3B) are considerably more deformed than are areas to the north (NN-3C, D, E, F). This may relate to the influence of left-1ateral strike-slip movement along the east-trending Pancake Range 1 ineament just south of Portuguese Mountain, as discussed by Ekren and others. ${ }^{22}$

The Chainman Shale is a weak, easily eroded rock unit that is extensively exposed, largely as low-relief "park" areas surrounded by mountainous terrain. In most cases this mountainuous terrain is predominantly volcanic (NN-3B, C, D), but near Portuguese Mountain (NN-3A) it is largely Devonian carbonates in the upper plate of a thrust fault. A typical exposure is bounded on one side by a high-angle fault and forms a topographic amphitheatre which drains across the fault (Figures 5,8 ). 


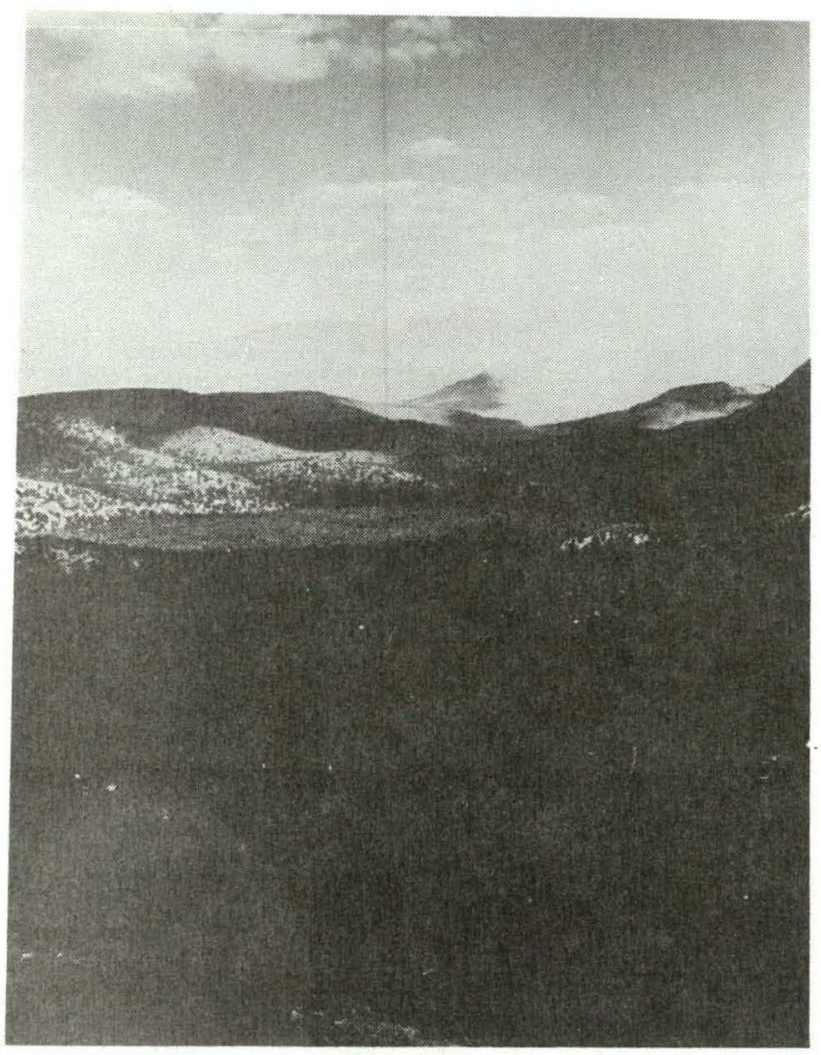

Figure 8. Typica1 "Park"-Type Chainman Shale Exposure in Pancake Range (NN-3D) (View east. Chainman Shale undelies low relief terrain in foreground. Hills to east are underlain by Quaternary and Tertiary volcanics in fault contact with Chainman Shale.)

In two areas (NN-3A; NN-3D, Figure 9) Chainman Shale clearly forms the lower plate of a major pre-volcanic thrust fault; and in two other areas (NN-3B; NN-3C, Figures 4, 10) a similar structural position has been modified by younger basin-range normal faulting. In the northern-most exposures (NN-3E, Figures 3, 11; NN-3F), Chainman Shale is topographically low but the structural configuration is less well understood. 


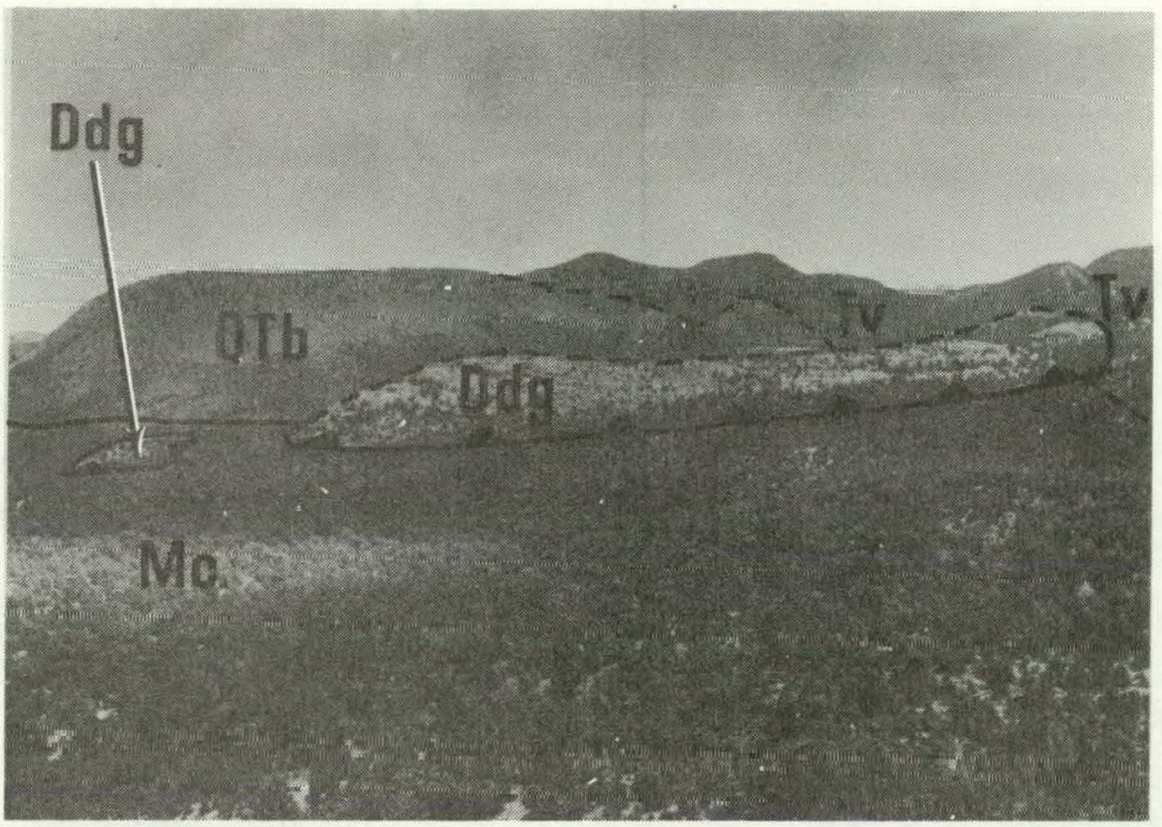

Figure 9. Klippe of Devil's Gate Limestone (Devonian) Overlying Chainman Shale (Mississippian) West of Big Louie Spring, Pancake Range (NN-3D) (View southeast. See Figure 5 for symbols.)

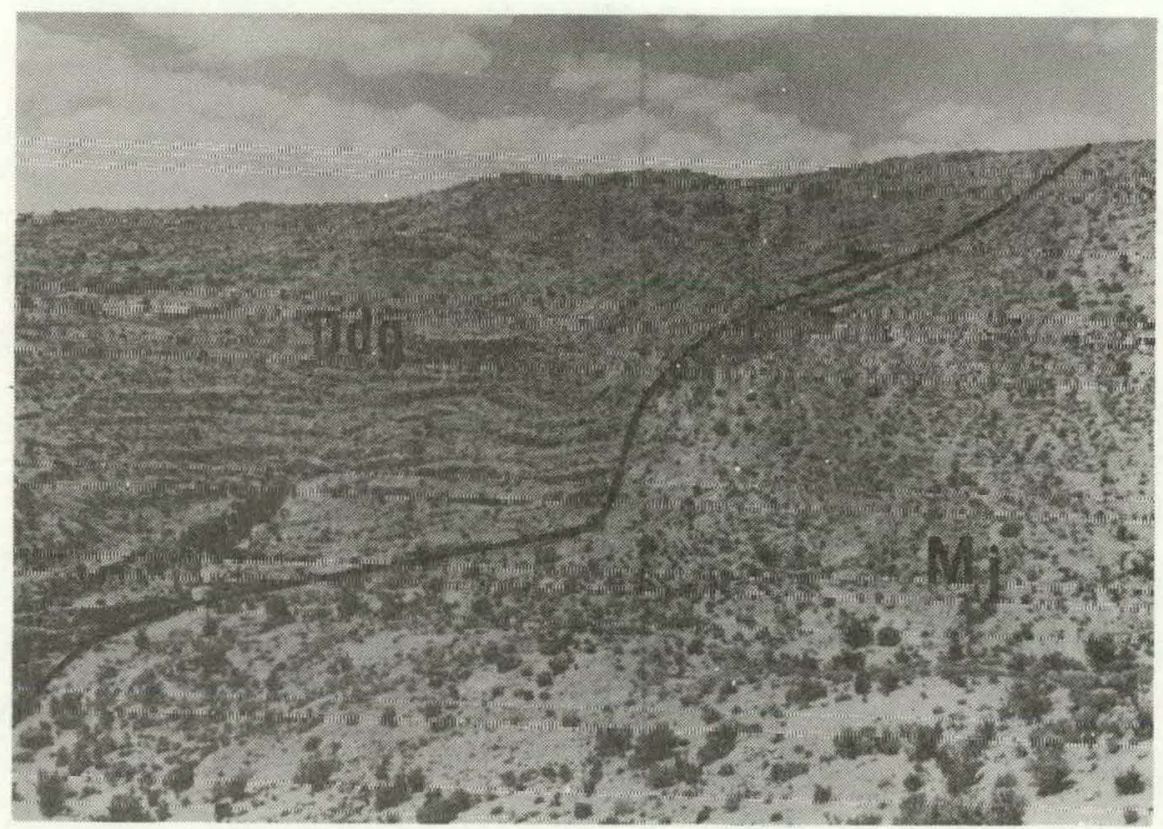

Figure 10. Thrust Fault Exposed in the Duckwater Hills, Pancake Range (NN-3C). (Devil's Gate Limestone (Devonian) is thrust over Joanna Limestone (Mississippian) (View north. This area lies just west of a high-angle fault cuntact with Chainman Shale. Note crumpling of strata in upper plate. See Figure 4 for symbols.) 


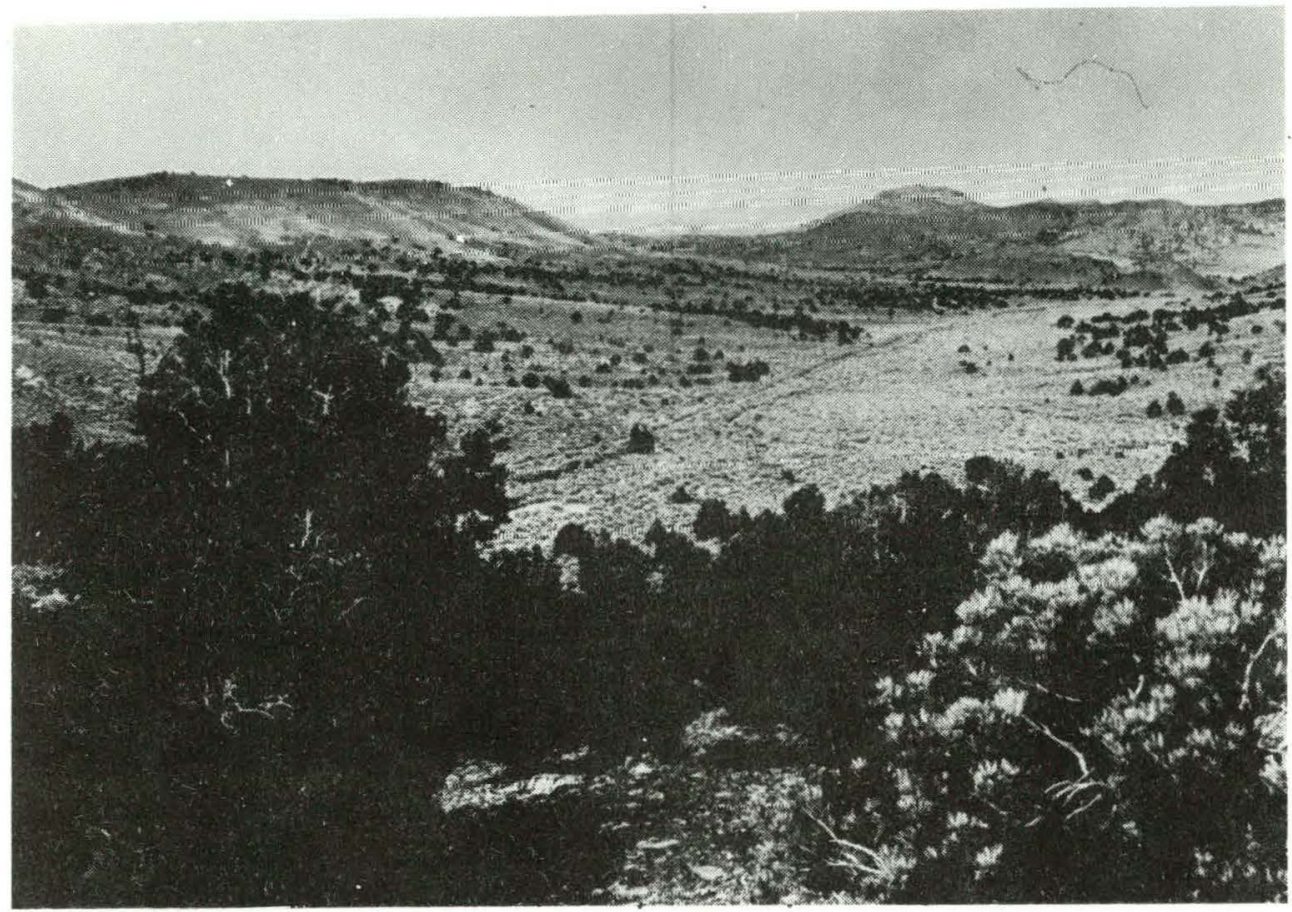

Figure 11. Chainman Shale Exposed North of Duckwater Peak, Pancake Range (NN-3E) (Shale underlies low area between more resistant coarser clastics of the Diamond Peak Formation (Mississippian). View north.)

White Pine Range (NN-4)--Moores and others ${ }^{8}$ describe the southern part of the White Pine range as a "north-trending faulted and doubly plunging anticlinal dome with Cambrian rocks exposed in its core in the southwestern part of the range.. . The anticline is inclined asymmetrically to the east." The west $1 \mathrm{imb}$ is restricted to Cambrian rocks dipping $5^{\circ}$ to $30^{\circ}$ west, whereas Cambrian through Tertiary rocks on the east $1 \mathrm{imb} \operatorname{dip} 30^{\circ}$ to $70^{\circ}$ east.

Thrust faults are along bedding planes or are slightly transgressive across bedding planes and concentrated on the steep west side of the range. Successively higher faults cut lower ones and are presumed to be younger upward. Characteristically, upper plate rocks are highly brecciated and in a normal stratigraphic sequence, but greatly thinned. In 
general, Chainman Shale exposures appear to be anomalously thin, presumably due to "tectonic denudation" during thrusting (NN-4A).8

The west margin of the range is a major normal fault with an estimated minimum of $1800 \mathrm{~m}(6000 \mathrm{ft})$ of vertical separation adjacent to Railroad Valley. 8 Synthetic normal faults cut Quaternary alluvium west of the major fault. ${ }^{2}$ The eastern range margin is a buried, possibly faulted, homocline in which Tertiary volcaniclastic rocks overlie Paleozoic sediments without notable discordance.

Horse Range and Horse Camp Basin (NN-4)--The Horse Range consists of two south-trending ridges underlain by Paleozoic strata separated by a valley underlain primarily by Tertiary sediments and volcanics that are mostly covered by alluvium. Within the west ridge are several low-angle younger-on-older thrust faults; whereas the east ridge is broadly folded and cut by scveral high-angle faults parallel to the ridge. Strata in both ridges generally dip east. The east ridge is also cut by several easttrending high-angle faults across which strata appear to dip progressively more steeply east as one goes south. The valley narrows southward and is no longer present near the Stone Cabin (NN-4B).

Horse Camp Basin forms a topographic reentrant between the White Pine Range and northern Grant Range whose east margin is strongly concave toward the west. Moores and others ${ }^{8}$ inferred the presence of a major fault system (the Ragged Ridge and Currant Summit fault zones) paralleling this curved boundary and suggest that the basin is a large-scale, internally faulted slump block.

Chainman Shale is exposed in the eastern ridge of the Horse Range a Lew miles oouth of Currant Sunmit (NN-4A) and in the area of low hills just north of Currant on the west edge of the Horse Camp Basin.

Moores and others ${ }^{8} 23$ make a strong case for a late Tertiary age for some of the thrusting and argue for a similar age for all major thrusts. Drewes ${ }^{24}$ challenged their interpretation and suggested a complex history 
of thrusts, volcanism, normal faulting, and gravity sliding dating from at least late Mesozoic time. At the one locale of Chainman Shale examined, $(\mathrm{NN}-4 \mathrm{~A})$, mapped exposures of the Joanna Limestone that stratigraphically underlies the shale are invariably topographically higher. This is attributed by Kleinhampl and $\mathrm{Ziony}^{2}$ to a combination of folding and normal faulting but is similar to areas in the Pancake and southern Grant Ranges where this topographic inversion is cased by thrust faulting.

Grant Range (NN-6)--The Grant Range is a generally east-tilted fault block. The range is underlain by strata ranging in age from Cambrian through Tertiary and intruded by a few relatively small granitic stocks in its southern part. The west margin of the range is marked by a wel1defined fault juxtaposing Paleozoic strata with Quaternary pediment deposits and alluvium. The east margin is a generally east-dipping, broadly folded homocline with successively younger strata exposed toward the White River Valley; easternmost Tertiary rocks are exposed as isolated monadnocks. As mapped by Kleinhampl and $\mathrm{Ziony},{ }^{2}$ the lowest Tertiary clastic and volcaniclastic strata (01igocene?) appear to overlie Pennsylvanian Ely Limestone with little or no angular discordance.

Thrust faults are found throughout the Grant Range and its southern extension, the Quinn Canyon Range (NN-6). Thrust faults are commonly restricted to Devonian and older rocks, but locally involve strata as young as Pennsylvanian. Thrust faults commonly juxtapose younger strata over older, although several are present that place older over younger strata. The thrusts are commonly cut by two sets of high-angle faults having generally east and north strikes.

Two Chainman Shale exposures were examined on the eastern homoclinal flank of the Grant Range. In one area (NN-6A), Chainman Shale is in the lower plate of a low-angle fault, and the upper plate contains a strongly thinned Ordovician-Devonian sequence. The base of the thrust is marked by a zone of brecciation and weak silicification of upper-plate limestones, suggestive of origin at a shallow crustal level. The other locale (NN-6B) has been mapped as a gentle anticline by Hyde and Huttrer ${ }^{7}$ and as part of 
the east flank homocline by Kleinhampl and Ziony. ${ }^{2}$ These differences could not be reconciled in the field because of poor exposures, but the presence of a strongly flowing artesian spring ( $\sim 70$ to $100 \mathrm{gal} / \mathrm{min}$ ) associated with the western 1 imestone-shale contact suggests that contact is probably a low-angle west-dipping fault.

White River Valley Area (NN-5)--Chainman Shale is locally exposed in the low hills on the east and west flanks of the White River Valley in the southeastern part of northern Nye County. The eastern hills south of Gap Mountain are a topographic extension of the east-tilted South Egan Range but, unlike the Egan Range, most strata observed tend to be tilted southwest. Tertiary Shingle Pass Tuff underlies about half the area, and the rest is underlain by variously oriented fault blocks of middle and late Paleozoic strata cut by high-angle faults of northwest and northeast strike. No thrust faults were mapped by Kleinhampl and Ziony ${ }^{2}$ or noted by the authors. Only one of the three areas examined (NN-5D) contains exposures good enough to allow a reasonable estimate of the proportion of clay-rich strata in the Chainman Shale. In general, the structure in the vicinity of the White River Valley exposures appears to be less complex than the Grant Range to the west. Some of this may be more apparent than real, however, because relief is generally lower and exposures are consequently poor.

\section{Subsurface Projections}

In the Pancake Range there is good evidence that Chainman Shale lies unconformably beneath Tertiary volcanic rocks at most locales (NN-3A, B, $C, D)$. At the northernmost exposures in and close to White Pine County around Red Rock Summit (NN-3E, F), strata believed to represent the upper part of the Chainman Shale are exposed extensively at the surface. Observations in several areas (NN-3A, C, D) as well as the mapping of Quinlivan and others ${ }^{25}$ suggest that Chainman Shale may be extensively present in the subsurface beneath the central Pancake Range as the slip surface (lower plate) of a major regional thrust fault system. In many areas, Chainman Shale may have formed an extensive erosion surface of low relief on which Tertiary volcanic rocks accumulated. 
In the White Pine and Horse Ranges, the one area of Chainman Shale observed ( $\mathrm{NN}-4 \mathrm{~A}$ ) appears to be anomalously thin and cannot be projected into the subsurface with confidence.

In the Grant Range, as in the Pancake Range, Chainman Shale underlies topographically low areas at least partly as. the lower plate of a thrust fault. Unlike Pancake Range exposures, regional evidence suggests that the Grant Range thrusts are of a more local extent and that subsurface projections cannot be made outside of the immediate area of outcrop.

In the White River Valley area, exposures are generally poor and clearly fault-bounded so that extensive subsurface projections cannot be made with confidence. The upper contact with Ely Limestone is exposed in one area (NN-5D) and a gently dipping $\left(10^{\circ}\right.$ to $\left.15^{\circ}\right)$, possibly complete section of shale may be present in the immediate subsurface.

\section{Mineral Resource Activity, Land Use, and Springs}

There are no active mines in the Pancake Range, but parts of the Chainman Shale in the Portuguese Spring area (NN-3B) have been recently staked, as has much of the western edge of the Duckwater Valley (east of NN-3D).

In the White Pine-Horse Range region no active mines are present, but the Currant Creek district ( $\mathrm{Au}, \mathrm{Ag}$ ) lies along the border of the Horse and White Pine Ranges north of US Highway 6. Claims have been staked recently along the Chainman Shale-Tertiary volcanic contact south and west of Currant Summit.

No active mines are present in the Grant or Quinn Canyon Range. The mines in the Troy Canyon district ( $W, A u$ ) (NN-6E) have been worked within the last $20 \mathrm{yr}$ and could open again if gold prices continue to rise. Several prospects and mines north of Troy Canyon (NN-6F) appear to have been long inactive. The Willow Creek district in the Quinn Canyon Range has produced some gold and silver but is presently inactive. The Quinn 
Canyon Range probably contains a large fluorspar resource associated with Tertiary volcanism. ${ }^{17}$

The Eagle Springs oil field at the foot of the Grant Range in Railroad Valley is only marginally active at present. The Trap Springs oil field several miles west of Currant on US Highway 6 now has more than 12 producing wells, and development drilling is continuing. Petroleum exploration, including seismic work and some exploratory drilling, is proceeding in the Duckwater Valley $(\mathrm{NN}-3)$, the northern part of Railroad Valley, and on the west side of the White River Valley (flanking NN-4).

Land use in most areas is directly related to ranching. Springs are used primarily for stock watering, and alfalfa is grown along Cherry Creek in the Quinn Canyon Range and along Currant Creek west of Currant Sumit. Ranches occupied year-round are present in Duckwater Valley, near Currant, along the east side of the White River Valley near Lund, along Cherry Creek or the east side of the Quinn Canyon Range, and at Nyala on the west side of the Quinn Canyon Range.

There is a general tendency for surface waters to be associated with Chainman Shale exposures. Springs are commonly associated with a structural or stratigraphic contact in which shale is topographically lower than the limestone or volcaniclastic aquifer (NN-3A, D, F; NN-6A, B). Springs issuing from within Chainman Shale are rare, and the one observed (NN-3B, Figure 2) is believed to be related to a fault. The tendency for water to be present on the surface is probably a function of the impermeability of the shale; water which flows on the surface commonly sinks into the subsurface when it flows over limestone, alluvium, and volcanic rock.

\section{Conclusions}

The Chainman Shale is the most widespread clay-rich rock unit in northern Nye County and appears to meet working guidelines outlined 
above better than any other shale-argillite in the region. The Pancake Range locales ( $N$ - 3 ) are estimated to contain between $75 \%$ and $90 \%$ clay shale and clay-rich siltstone and are at least $150 \mathrm{~m}(500 \mathrm{ft})$ thick at each of the 6 areas examined. Local evidence indicates that Chainman Shale probably underlies volcanic rocks adjacent to most areas examined in the central Pancake Range (NN-3A, B, C, D). Incomplete regional evidence suggests that much of the central Pancake Range is underlain by Chainman Shale as the lower plate of a regional thrust fault system. Exposures are not as extensive in the Horse and Grant Ranges (NN-4, NN-6). Although most sections observed appear to be dominated by clay-rich strata, subsurface projections generally cannot be made with confidence outside the immediate area of exposure. Shale also dominates most White River Valley area exposures (NN-5), but all areas examined are cut by closely spaced highangle faults; confident subsurface projections are difficult.

In most areas, the Chainman Shale appears to be highly deformed internally; however, the fact that it rarely shows visible alteration even in close proximity to bounding faults that are mineralized suggests that the shale's low permeability has been maintained despite deformation.

Most historic mining activity has been in the Grant, white Pine, and Horse Ranges, and none of the mines are presently active. Recently staked claims were found in two exposure areas (NN-3B, NN-4A) and within a few miles of two others (NN-3D,E). Most land in the ranges and flanking valleys is grazing land for ranches located in Duckwater Valley, Railroad Valley, White River Valley, and along Cherry Creek in the Quinn Canyon Range.

\section{Overall Summary}

of all the clay-rich rocks examined, Chainman Shale appears to meet working guidelines better than any of the other shale-argillite occurrences in the study area. Particularly attractive areas in northern Nye 
County are located in the central and northern Pancake Range, where subsurface projections indicate occurrence of shale in the subsurface. We note, however, that Chainman Shale generally is internally deformed even at the most favorable locales. 
References

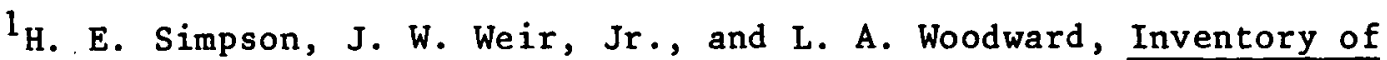
Clay-Rich Bedrock and Metamorphic Derivatives in Eastern Nevada, Exluding the Nevada Test Site, USGS Open-File Rpt 79-760, 1979.

${ }^{2}$ F. J. Kleinhamp 1 and J. I. Ziony, Preliminary Geologic Map of Northern Nye County, Nevada, USGS Open-File Map, $196 \overline{7}$.

${ }^{3}$ G. W. Shurr, The Pierre Shale, Northern Great Plains: A Potential Isolation Medium for Radioactive Waste, USGS Open-File Rpt 77-776, 1977.

${ }^{4}$ T. E. Eakin, A Regional Interbasin Groundwater System in the White River Area, Southeastern Nevada, Water Resources Research, 2, 1966, PP $\overline{251-2} \overline{7} \overline{1}$.

${ }^{5}$ C. M. Tschanz and E. H. Pampeyan, Geology and Mineral Deposits of Lincoln County, Nevada, Nevada Bur of Miñes and Geology Bul1 73, 197.0 .

${ }^{6}$ S. E. Cebul1, Bedrock Geology and Orogenic Succession in Southern Grant Range, Nye County, Nevada, Am Assoc Petroleum Geologists Bu11, 54, $1 \overline{9} 70$, pp $18 \overline{2} \cdot \overline{8}-1842$.

7J. E. Hyde and G. W. Huttrer, Geology of Central Grant Range, Nevada, Am Assoc Petroleum Geologists Buli, 54, 1970, pP 503-521.

${ }^{8}$ E. M. Moores, R. B. Scott, and W. W. Lumsden, Tertiary Tectonics of the White Pine-Grant Range Region, East-Central Nevada, and Some Regional Implications, Geol Soc America Bul1, 79, 1968, pp 1703-1726.

${ }^{9}$ W. D. Quinlivan and C. L. Rogers, Geologic Map of the Tybo Quadrangle, Nye County, Nevada, USGS Misc Inv Map I- $\overline{8} \overline{2} 1,1974$.

$10_{H}$. G. Ferguson, Geology of the Tybo District, Nevada, Univ of Nevada Bul1, 27, No. 3, 1933 .

$11 \mathrm{~J}$. H. Schilling, Metal Mining Districts of Nevada, 3rd ed, Nev Bur of Mines and Geol Map $3 \overline{7,1976 . ~}$

12 H. G. Ferguson and G. H. Cathcart, Geology of the Round Mountain Quadrangle, Nevada, USGS Quad Map GQ-40, 1954.

13H. G. Ferguson, Geology and Ore Deposits of the Manhattan District, Nevada, USGS Bull 723, 1924.

${ }^{14}$ M. Kay and J. P. Crawford, Paleozoic Facies from the Miogeosynclinal to the Eugeosynclinal Belt in Thrust Slices, Central Nevada, Geol Soc America Bul1, 75, 1964, PP 425-454.

15F. J. Kleinhampl and J. I. Ziony, written communication, 1978. 
${ }^{16}$ A. L. Payne and K. G. Papke, Active Mines and Oil Fields in Nevada, 1976, Nev Bur of Mines and Geol Map 55, 1977.

${ }^{17} \mathrm{C}$. L. Sainsbury and F. J. Kleinhampl, Fluorite Deposits of the Quinn Canyon Range, Nevada, USGS Bull 1272-C, 1969.

18 F. G. Poole, "Flysch Deposits of Antler Foreland Basin, Western United States," in Tectonics and Sedimentation, ed W. R. Dickinson, Soc Econ Paleontologist $\bar{s}$ and Mineralogists Spec Pub 22, 1974, pp 58-82.

${ }^{19}$ F. G. Poole and C. A. Sandberg, "Mississippian Paleogeography and Tectonics of the Western United States," in Paleozoic Paleography of the Western United States, J. H. Stewart et al, eds, Soc Econ Paleontologists and Mineralogists, Pacific Coast Paleogeography Symp I, 1977, pp 67-85.

$20_{R}$. K. Hose and M. C. B1ake, Jr., Geology and Mineral Resources of White Pine County, Nevada (Part 1 - Geology), Nev Bur of Mines and Geol Bu11 85, 1976, pp 1-35.

$21 \mathrm{~J}$. A. Scott and E. W. Brooker, "Geological and Engineering Aspects of Upper Cretaceous Shales in Western Canada," Geol Surv of Canada Special Paper $66-37,1966$.

${ }^{22}$ E. B. Ekren, R. C. Bucknam, W. J. Carr, G. L. Dixon, and W. D. Quinlivan, East-Trending Structural Lineaments in Central Nevada, USGS Prof Paper $986,1976$.

${ }^{23}$ E. M. Moores, R. B. Scott, and W. W. Lumsden, Tertiary Tectonics of the White Pine-Grant Range Region, East-Central Nevada, and Some Regional Implications: Reply, Geol Soc America Bull, 81, 1970, pp 323-330.

${ }^{24} \mathrm{H}$. Drewes, Tertiary Tectonics of the White Pine-Grant Range Region, East-Central Nevada, and Some Regional Implications: Discussion, Geol Soc America Bull, 81, 1970, pP 319-322.

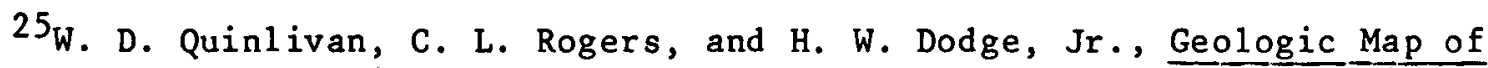
the Portuguese Mountain Quadrangle, Nye County, Nevada, USGS Survey Misc Inv Map I-804, 1974. 
APPENDIX

Field Reconnaissance Checklists 
FIELD RECONNAISSANCE CHECKLIST

Phase II Investigations: Fine-Grained (fn/grn)

Locale Designation $\mathrm{NN}-1 \mathrm{~A}$

Clastic Sedimentary Rocks and Metamorphic

Derivatives in Eastern Nevada

Sublocale Name West end

Manhattan Wash

1. Stratigraphic nave/

designator Toquima Fm (Ferguson, 1924) or Palmetto Fm (Ferguson \& Cathcart, 1954)

2. Unit above: 1ith/thick Diablo Fm (Ferguson \& Cathcart, 1954); conglomerate; not exp here

3. Unit below: lith/thic': Gold Hill Fm (Ferguson, 1922); quartzites; th?; not exp here

4. Topo maps: $1^{\circ} \times 2^{\circ}$ Tonopah 7-1/2' Seyler Peak, NV

5. Other -Sec NE $1 / 4$ NE $1 / 4$ Sec 21 Twnship $8 \mathrm{~N}$ Range $43 \mathrm{E}$

6. Distr-Brng -from =-

7. Exp area \& dimensions See Manhattan-Mt Moriah. This area is on western edge of outcrop contiguous with Manhattan-Mt Moriah sublocale on northeast. Area estimate includes area between and is included on other checklist. \%Bedrock exp $\sim 70$ in canyon walls

8. Stratigraphy (Estimated: By traverse down canyon Measured --

9. Unit-thickness exp Unknown because of deformation Fn-grn\% 60 Clay-mineral rich \% Probably none--rx are phyllites

10. Lat continuity Almost none because of structure Induration and Colors Gray to greenish gray; well "indurated" gencrally brittle

11. Thickness-clay horizon Unknown--original stratigraphy cannot be seen because of deformation and metamorphism

12. Samples \& locations None

13. Other Lithologies other rocks in sequence include fg quartzite and quartzose siltstone \& lesser metamorphosed shaley limestones--usually in thin $(<5 \mathrm{~cm})$ beds. Quartz veins \& veinlets are locally abundant \& intruded both concordently \& discordently relative to cleavage

14. "Bedding" Phyllitic slaty cleavage: N22W, 53SW; phyllite: N10E, 30W-N5E, 85W (def. N trending fold); spocted phyllite: N27W, 15SW; slaty cleav: N65E, 30SE; phyllite: N35W, 50SW

15. Fiss1/Cleavage/Foliation A11 meas attitudes are well dev slaty cleav or phyllitic foliations. Rocks vary from flaggy to slabby

16. Contacts/Boundaries Base Not exp this locale

17. Top Upper surface is erosional or overlain by thin alluvial \& pediment gravels on flanks of channel

18. Other Channel gravels are up to $80^{\circ}$ thick.

19. Structure. Best map reference Ferguson (1924) "Geology and Ore Deposits of the Manhattan District, Nevada" USGS Bulletin 723

20. Kegional Setting Occurs on W flank of Toquima Range just SW of faulted WNW-plunging anticlinal structure of Manahttan; area occurs on SW flank of this structure.

21. Faults Numerous small-scale faults are inferred between exposures of varying attitude and lithology. No obvious uniform trend; very minor bedding plane slip noted.

22. Joints Rocks are very highly fractured. Fractures are highly variable but tend to strike about $\mathrm{N}$; continuity not evident. 
FIELD RECONNAISSANCE CHECKLIST (cont)

Locale Designation NN-1A

Sublocale Name West end Manhattan Wash

23. Folds Abundant from small amplitude $(1 \mathrm{~cm})$ intrafolial flexures in layers with high ductility contrasts to large amplitude $(5-10 \mathrm{~m})$ folds in phyllitic sequences. Fold axes tend to trend $\mathrm{N}$ and NNW and plunge gently $\mathrm{N}$ or $\mathrm{S}$. Two photos show style of deformation in sequence with high-ductility contrast $\&$ in monolithologic phyllites.

24. Topography Exposures occur on both sides of wash in area of gently rolling hills; sloping pediment on $W$.

25. Slopes, max-min In hills, $25 \%-20 \%\left(14^{\circ}-11^{\circ}\right)$; in pediment, $5 \%-4 \%\left(3^{\circ}-2^{\circ}\right)$ Estimated Avg =-

26. Ridge gradients NA (see above) Lengths

27. Stm gradients $3^{\circ}(5 \%)$ to NW Channel width This area $60-100 \mathrm{~m}(200-300$ ft). Most much 1ess.

28. Dist.-brng to major topo break Area lies on topo break between bedrock and pediment.

29. Miscellaneous: Access rte $-34.1 \mathrm{mi}$ N of US 6 on NV 8 A (0.9 past Peavine Campground Turnoff), make right on dirt road to $\mathrm{E}$; go $1.9 \mathrm{mi}$, turn $\mathrm{N}$ across dredged tailing $0.4 \mathrm{mi} 06 \mathrm{p}$ exposures in prospected area in $\mathrm{N}$-trending wash.

30. Known drill holes None observed; probably present due to mining activity

31. Known springs None observed; Palo Alto spring mapped $1300 \mathrm{~m}$ (4200') N33E of locale.

32. Mines (active/abandoned) Area riddled with shafts, adits, \& open cuts \& channel

33. Prospects/claims gravels have been excavated locally to bedrock $\left(\sim 80^{\prime}\right) \&$ presumably placer mined; no present activity:

34. Mineralization/alteration Penetrative alteration is minimal in phyllites but abundant thin quartz veinlets with some oxidation common.

35. Possible subsurf proj Presence of shafts and adits in pediment to $W$ suggests bedrock is present beneath thin gravels.

36. Possible testhole sites Probably not required; adits are largely still open and accessible.

37. Possible geophysical sites Not located.

38. Other Ferguson, H. G. (1924) "Geology and Ore Deposits of the Manhattan District, Nevada," USGS Bullet in 723. Ferguson, H. G., and Cathcart, S. H. (1954). "Geologic Map of the Round Mountain Quadrangle; Nevada," USGS Geol Quad Map GQ-40. Kleinhamp1, F. J. and J. I Ziony (1967). "Preliminary Geologic Map of Northern Nye County, Nevada," USGS Open-File Map.

Geologist J. Connolly Organization UNM Date $6 / 18 / 79$ 
FIELD RECONNAISSANCE CHECKLIST

Phase II Investigations: Fine-Grained ( $f n / g r n)$

C1astic Sedimentary Rocks and Metamorphic

Derivatives in Eastern Nevada
Locale Designation $\mathrm{NN}-1 \mathrm{~B}$

Sublocale Name ManhattanMt Moriah

1. Stratigraphic name/

designator Palmetto Fm (OGp) (Ferguson and Cathcart, 1954) equivalent here to 06sl of Kleinhampl and Ziony (1967) \& includes Mayflower Schist, Zanzibar Limestone and Toquima Fm of Ferguson (1924). Larger designation used here because reconnaissance suggests units are probably intercalated stratigraphically and/or tectonically.

2. Unit above: lith/thick Diablo $F_{m}$ (Pd) coarse clastics, minor slate, dolomite unconformably overlain by tuffs and flows of Tertiary age (TV).

3. Unit below: 1ith/thick Gold Hill $\mathrm{Fm}(6 \mathrm{~g})$ quartzite and lesser qz-mica schist

4. Topo maps: $1^{\circ} \times 2^{\circ}$ Tonopah $15^{\prime}=$ 7-1/2' Manhattan

5. Other $=$ Sec SW1/4, NE1/4,24 Twnship $8 \mathrm{~N}$

6. Distr-Brng =- from =-

7. Exp area \& dimensions $\sim 36 \mathrm{~km}^{2}\left(22 \mathrm{mi}^{2}\right) \%$ Bedrock exp 20 . Much covered by float of slate phyllite \& quartzite includes all exposure of Palmetto $\mathrm{Fm}$ to $\mathrm{S}$ and $\mathrm{W}$ of Manhattan. Area is $\max 14.5 \mathrm{~km}(9 \mathrm{mi})$ long in $\mathrm{E}-\mathrm{W}$ direction, $8 \mathrm{~km}(5 \mathrm{mi})$ wide in $\mathrm{N}-\mathrm{S}$ direction, generally wedge-shaped tapering to E. Mapped areas and structures of Ferguson and Cathcart (1954) and Kleinhampl and Ziony (1967) are in good agreement in this area.

8. Stratigraphy (Estimated By foot traverse Measured --

9. Unit-thickness exp Unknown due to structure Fn-grn\% Perhaps 60 Clay-mineral rich \% Probably none

10. Lat continuity Poor (see structure sections) Induration \& Colors Metamorphosed to slate \& phyllite; light to dark gray

11. Thickness-clay horizon NA (no clay)

12. Samples \& locations None taken

13. Other Lithologies Dominant rock types include spotted phyllites, dark calcareous slates, lesser quartzites and minor pods of recrystallized gray limestone. Quartzites are generally highly recrystallized, brecciated, \& silicified while other rock types are locally silicified.

14. "Bedding" A11 phyllitic to slaty cleavage: N40W, 15SW; N55W, 11SW; N15E, 15SE in sma11 area just $E$ of Mt Moriah; no clear indication of relation to bedding.

15. Fiss1/Cleavage/Foliation Well developed phyllitic to slaty cleavage; general elongation of lenses of varying lithology parallel to foliation suggests it may be equivalent to bedding.

16. Contacts/Boundaries Base Not well exposed. Generally mapped as faulted.

17. Top Pd not exposed in contact with 06p. Unconf overlain \& faulted against TV.

18. Other Intruded on south by Cretaceous (?) granite $(\mathrm{Kg})$ and by associated aplite in outcrop area. Degree of metamorphism suggests close proximity to $\mathrm{Kg}$ at depth throughoul area. Locally overlain by thick Qa1 in canyons. Much placer activity in Manhattan Canyon. 
FIELD RECONNAISSANCE CHECKLIST (cont)

Locale Designation NN-1B

Sublocale Name Manhattan-Mt Moriah

19. Structure. Best map reference Ferguson, H. G. (1924). "Geology and Ore Deposits of the Manhattan District, Nevada"; USGS Bulletin 723 (Map 1:24 000) area to E covered by Kleinhampl and Ziony (1967). "Preliminary Geologic Map of Northern Nye County, Nevada," USGS Open-File Map.

20. Regional Setting Toquima Range is an internally faulted generally W-tilted fault block range with high-angle range margin fault exposed on $E$ side. Manhattan area is a broad, internally deformed, gently N75W-plunging anticline with Gold Hill Fm at core; this area is on SW flank of this structure. Anticline is strongly overturned toward the NE.

21. Faults North border near Manhattan is WNW-striking fault, probably dips SW $\sim 60^{\circ}-70^{\circ}$. Numerous outcrop scale faults, generally with low dips observed in roadcuts.

22. Joints Rocks are highly fractured; no uniform orientation noted.

23. Folds Numerous tight-to-isoclinal, generally N-NE overturned folds observed in roadcuts; prob related to major fold structure (Item 20).

24. Topography Exposures in generally low hills and foothills on W flank of Toquima Range bordering Big Smoky Valley.

25. Slopes, max-min Generally to $\mathrm{W}$, avg range: $20 \%-60 \%\left(11^{\circ}-31^{\circ}\right)$ Estimated Avg =-

26. Ridge gradients =Lengths =-

27. Stm gradients Manhattan Gulch-4\% (2.4\%) to W Manhattan Gulch is full of old dredge tailings.

Channel width $90 \pm 180 \mathrm{~m}\left(300-600^{\prime}\right)$

28. Dist.-brng to major topo break This location $\sim 4.0 \mathrm{~km}(2.5 \mathrm{mi})$ E of pediment of Big Smoky Valley. Valley is bordered by $06 p$ outcrop.

29. Miscellaneous: Access rte From Jct NV $8 \mathrm{~A}$ and US 6 (5 mi E of Tonopah) go N on NV 8A $37 \mathrm{mi}$ to Manhattan turnoff, proceed $E$ on NV $69 \sim 5.3 \mathrm{mi}$ to Mt Moriah Cemetery turn to S. Before cemetery gate, bear right to abandoned mine in Mt Moriah $300 \mathrm{~m}\left(1000^{\prime}\right)$ to $W$.

30. Known drill holes Numerous; probably present due to past exploration activity

31. Known springs None observed. Several mapped in area on Manhattan 7-1/2' quad.

32. Mines (active/abandoned) Area has been intensely prospected \& over 60 shafts and adits are

33. Prospects/claims___ shown on Manhattan 7-1/2' Quad. At least two mining operations are active in $6 g$ outcrop area to $E$; both open pit.

34. Mineralization/alteration Phyllites \& limey rocks show frequent oxidation along fractures and small faults; silicified zones in qzites \& qz veins are locally abundant.

35. Possible subsurf proj May extend to $W$ under narrow portion of Big Smoky Valley.

36. Possible testhole sites --

37. Possible geophysical sites --

38. Other =- 
FIELD RECONNAISSANCE CHECKLIST

Phase II Investigations: Fine-Grained ( $\mathrm{fn} / \mathrm{grn}$ )

Clastic Sedimentary Rocks and Metamorphic

Derivatives in Eastern Nevada
Locale Designation $\mathrm{NN}-1 \mathrm{C}$

Sublocale Name East

Manhattan Wash

1. Stratigraphic name/

designator Palmetto $\mathrm{Fm}$ (OGp) (of Ferguson \& Cathcart, 1954) equiv. to 06s 1 of Kleinhamp1 and Ziony, 1967.

2. Unit above: 1ith/thick Tuffs, flows, dikes of Tertiary Age (TV); unconformably overlies oep.

3. Unit below: 1ith/thick Gold Hill Fm (6g); Qzite and Qzose phyllites. Few 1000'; base not exposed.

4. Topo maps: $1^{\circ} \times 2^{\circ}$ Tonopah $15^{\prime}--$ 7-1/2' Belmont $W$

5. Other $=-$ Sec Along section line bet. 24 and 25 Twnship $8 \mathrm{~N}$ Range $44 \mathrm{E}$

6. Distr-Brng -from

7. Exp area \& dimensions $-12.1 \mathrm{~km}^{2}\left(4.7 \mathrm{mi}^{2}\right)$ $\%$ Bedrock exp 20 or less. Somewhat better along wash. Area is strongly elongate in WNW direction, $\max \sim 10.5 \mathrm{~km}(6.5 \mathrm{mi}) 1$ ong $1.6-0.8 \mathrm{~km}(1-1 / 2 \mathrm{mi})$ (or less) wide.

8. Stratigraphy (Estimated By foot traverse Measured --

9. Unit-thickness exp -Fn-grn\% Perhaps 50 Clay-mineral rich \% Probably none

10. Lat continuity Probably poor because of int. deformation Induration \& Colors $s 1 a t e s \&$ phyllites variably brittle; dark to light gray.

11. Thickness-clay horizon Rocks are slaty to phyllitic; probably no clay minerals.

12. Samples \& locations None taken

13. Other Lithologies Rocks of 06 p are predominantly slates and spotted phy11ites that are locally carbonate-rich. Along creek a highly fractured \& broken lens of vfg quartzite (or silicious argillite) is $55 \mathrm{~m}\left(180^{\prime}\right)$ thick in slate-phyllite sequence.

14. "Bedding" N80W, 85-N-bedding in quartzite lens; N55W, 70NE: slaty cleavage in calcareous slate.

15. Fiss1/Cleavage/Foliation We11-developed slaty cleavage

16. Contacts/Boundaries Base Not wel1-exposed. Generally mapped as moderately to gently S-dipping thrust with $G g$.

17. Top Not well exposed. Unconformably overlain by Tertiary volcanics

18. Other $06 \mathrm{~g}$ includes several thick sandstone lenses.

19. Structure. Best map reference Ferguson, H. G. (1924). "Geology and Ore Deposits of Manhattan District, Nevada," USGS Bulletin 723 (map scale 1:24,000). Covers area mostly W of this area. This area is covered by Kleinhampl and Ziony (1967). "Preliminary Geologic Map of Northern Nye County, Nevada"; USGS Open-File Map, Scale 1:200 000.

20. Regional Setting Occurs on NE flank of gently WNW-plunging overturned (to NE) and faulted anticline of Manhattan Area (Ferguson, 1924). 
FIELD RECONNAISSANCE CHECKLIST (cont)

Locale Designation NN-1C

Sublocale Name East Manhattan Wash

21. Faults Thrust with $6 g$ on S margins strikes WNW, dips moderately to gently SW. This fault cut by several NNE striking high-angle (tear?) faults.

22. Joints Sandstone lens highly fractured with fractures often filled by gz veinlets.

23. Folds Exposures of slates \& phyllite are poor, but rocks appear to be internally folded, based on several small outcrops.

24. Topography Exposures occur in fairly gentle mountainous area $E$ of crest of Toguima Range.

26. Ridge gradients =- Lengths =-

27. Stm gradients E Manhattan Wash $-3 \%\left(1.8^{\circ}\right)$ to SE_Channel width 15-30 m (50-100')

28. Dist.-brng to major topo break $\sim 1800 \mathrm{~m}(6000 \mathrm{ft})$ 54SW to pediment fan complex of Ralston Valley.

29. Miscellaneous: Access rte From Jct NV 8A and US 6 (5 mi E of Tonopah), go N on NV 8A 13 mi to Belmont (NV 82) turnoff. Proceed NE 17-1/2 mi.to Jct W NV 69 (second sign for Manhattan Turnoff). Turn NW $\sim 3.5 \mathrm{mi}$ (past abandoned mines). 06p outcrops examined are along stretch of road that trends due $N$.

30. Known drill holes None noted

31. Known springs Keller Spring $2000^{\prime} S 18^{\circ} \mathrm{E}$; no flow but abundant vegetation.

32. Mines (active/abandoned) No present activity; several abandoned mines \& adits in area

33. Prospects/claims_laround Keller Spring. No recent claim posts noted.

34. Mineralization/alteration Silicification common, largely around margins of quartzite lens probably related to faulting.

35. Possible subsurf proj May be present below TV on north margin.

36. Possible testhole sites --

37. Possible geophysical sites --

38. Other --

Geologist J. Connolly Organization UNM Date $5 / 18 / 79$ 
FIELD RECONNAISSANCE CHECKLIST

Phase II Investigations: Fine-Grained (fn/grn)

Clastic Sedimentary Rocks and Metamorphic

Derivatives in Eastern Nevada
Locale Designation NN-1D

Sublocale Name Monarch

1. Stratigraphic name/

designator Ord-Cam Shale \& Limestone (oes1) (Kleinhampl\& Ziony, 1967)

2. Unit above: lith/thick Tertiary Volcanic (TV) \& intruded by granitic rocks ( $\mathrm{Kg}$ )

3. Unit below: lith/thick? Possibly Gold Hill Fm of Manhattan \& Belmont areas. Not exposed here.

4. Topo maps: $1^{\circ} \times 2^{\circ}$ Tonopah $15^{\prime}$-7-1/2' Belmont $\mathrm{W}$

5. Other -- Sec NE1/4, Sec 22, plus parts of secs $10,11,14,15$ Twnship $8 \mathrm{~N}$ Range $45 \mathrm{E}$

6. Distr-Brng S10W $7300 \mathrm{~m}\left(24000^{\prime}\right)$

from Belmont Site

7. Exp area \& dimensions $6.5 \mathrm{~km}^{2}\left(2.5 \mathrm{mi}^{2}\right)$ \%edrock exp $\ll 5$; mostly covered by pediment with gravels up to few meters thick. One good bedrock exp in caved shaft just SE of mine shack.

8. Stratigraphy (Estimated Traverse by foot. Measured =-

9. Unit-thickness exp Unknown Fn-grn\% Float 90\%; bedrock exp rare. Clay-mineral rich \% --

10. Lat continuity Unknown Induration and Colors Dark green-black well-indurated, hard brittle

11. Thickness-clay horizon Unknown

12. Samples \& locations None

13. Other Lithologies Dominant lithology appears from largely float exposures to be a tough silicious argillite with some slate. Argillites often have calcite stringers.

14. "Bedding" Cannot be defined because of poor outcrop. One attitude in highly altered caved shaft--N85W, 36N in slaty cleavage. Probably not representative. N7E, 65E in same adit. Rocks highly contorted.

15. Fiss1/Cleavage/Foliation Shows well-developed metamorphic cleavage, usually slaty. Float exp is often platy, suggesting fissility.

16. Contacts/Boundaries Base Not exposed.

17. Top Not exposed.

18. Other Exposures are very poor in $S$ part of area; $N$ part exposures shown as better by Kleinhampl \& Ziony (1967). Overlapped by TV \& intruded by $\mathrm{Kg}$. in hills to $\mathrm{N}$.

19. Structure. Best map reference Kleinhampl \& Ziony (1967) "Prelim Geologic Map of Northern Nye Co, Nevada," USGS Open-File Report.

20. Regional Setting Area lies on structural-topographic divide between the predominantly volcanic Monitor Range on $E$ and largely intrusive part of the Toquima Range on $W$.

21. Faults Prospect near Monarch Ruins is in highly sheared, N trending zone, probably a mineralized fault zone between oesl and TV.

22. Joints Fractures filled with oxidized material common as well as filled fractures mentioned in I tem 34. 
FIELD RECONNAISSANCE CHECKLIST (cont)

Locale Designation $\mathrm{NN}-1 \mathrm{D}$

Sublocale Name Monarch

23. Folds Small-scale folds are common in silicous argillite float found near prospects. Not obvious because of exposure, but much internal deformation is probably concealed.

24. Topography Very gentle pediment surface graded $W$ in area abutted by 1 ow hill on $S$ containing numerous prospects, and entire outcrop area investigated.

25. Slopes, max-min $17 \%-6 \%\left(10^{\circ}-4^{\circ}\right)$ Estimated Avg $10 \%\left(6^{\circ}\right)$

26. Ridge gradients $\operatorname{Max} 17 \%\left(10^{\circ}\right)$ Lengths $\sim 1300 \mathrm{~m}\left(4000^{\prime}\right) \max$

27. Stm gradients $6 \%\left(4^{\circ}\right)$ Channel width up to $5 \mathrm{~m}$

28. Dist.-brng to major topo break Area borders Ralston Valley on the $W$ and occupies the divide between Ralston and Monitor Valleys to the E.

29. Miscellaneous: Access rte $N$ on NV 82 (from NV $8 \mathrm{~A}$ ), $219.5 \mathrm{mi} ; 2.1 \mathrm{mi} E$ on dirt road, and $0.5 \mathrm{mi} N$ on $\mathrm{NW}$ trending trail ( $4 \mathrm{WD}$ only)

30. Known drill holes None noted, but may be present because of prospecting.

31. Known springs None noted.

32. Mines (active/abandoned) Hil1 on S contains about 6 abandoned shafts and numerous prospect pits in altered green rock (slate?)

33. Prospects/claims Claim posts remain covering most of area. Most recent stakes by Hughes Tool Co.

34. Mineralization/alteration Green (propylitic) alteration is abundant in hill to $\mathrm{S}$ and appears to be zone-prospected. May be related to alt along N-S fault. Prospect with exp. slate is highly brecciated with limonitic alteration and caliche type calcite; green (secondary?) Cu stain also present.

35. Possible subsurf proj Cannot be evaluated from surface data.

36. Possible testhole sites May underlie much of pediment.

37. Possible geophysical sites?

38. Other =- 
FIELD RECONNAISSANCE CHECKLIST

Phase II Investigations: Fine-Grained ( $\mathrm{fn} / \mathrm{grn}$ )

$\mathrm{Clastic}$ Sedimentary Rocks and Metamorphic

Derivatives in Eastern Nevada
Locale Designation $\mathrm{NN}-1 \mathrm{E}$

Sublocale Name Mariposa

Canyon

1. Stratigraphic name/

designator Palmetto Fm (Ferguson and Cathcart, 1954) (oep) Equivalent to oesl of Kleinhampl and Ziony (1967).

2. Unit above: lith/thick Diablo Fm (Pd); coarse clastics; not exp this part of range. Overlapped by Tertiary tuffs and flows (TV).

3. Unit below: 1ith/thick Gold Hill Fm ( $\left.\theta_{g}\right)$; quartzite and quartzose schists; not exp. this part of range.

4. Topo maps: $1^{\circ} \times 2^{\circ}$ Tonopah $15^{\prime}--$ 7-1/2' Round Mt. Southernmost part of area is on adjacent $N$ edge of Manhattan $7-1 / 2^{\prime}$ quad.

5. Other Round Mt $30^{\prime}$ quadrangle. No longer published. Sec (not surveyed) Twnship $=-$ Range --

6. Distr-Brng $\sim 1800 \mathrm{~m}\left(6000^{\prime}\right)$ N75E from SE corner Sec 13, T9N, R43E (brass cap)

7. Exp area \& dimensions $-3.9 \mathrm{~km}^{2}\left(2.5 \mathrm{mi}^{2}\right)$ \% Bedrock exp Less than 20; most slopes rubble-covered.

8. Stratigraphy (Estimated by foot traverse Measured --

9. Unit-thickness exp Cannot be estimated because of internal deformation.

Fn-grn\% Perhaps (phyllite, slate) 40

Clay-mineral rich \% Probably none

10. Lat continuity Appearg to be poor Induration and Colors Well indurated slate \& phyllite. Dark to light gray.

11. Thickness-clay horizon No clay

12. Samples \& Lócartons Nune

13. Other Lithologies oep here composed of interbedded and structurally intercalated dark limestone, calcareous slate, phyllite, spotted and knotty phyllite and subordinate chert, mostly as concretions in limestone. Limestone "ledges" appear to increase toward S, approximately "updip."

14. "Bedding" Calcarenus slate: N80W, 68S; slate: N70W, 35s; Fe chert: N60W, 50s; knotty phyllite: N10E, 45SW

15. Fiss l/Cleavage/Foliation A11 rocks tend to show metamorphic cleavage, locally strongly phyllitic.

16. Contacts/Boundaries Base Not exposed

17. Top Pd not present. Overlapped by TV on $S$.

18, Other Intruded by Cretaceous (?) granitic rocks on $\mathrm{N}(\mathrm{Kg})$ 
FIELD RECONNAISSANCE CHECKLIST (cont)

Locale Designation NN-1E

Sublocale Name Mariposa Canyon

19. Structure. Best map reference Kleinhampl and Ziony (1967). "Preliminary Geologic Map of Northern Nye County, Nevada," USGS Open File Map; also covered in less detail on Ferguson and Cathcart (1954). "Geologic Map of the Round Mountain (30') Quadrangle, USGS Geol. Quad Map GQ40, $1: 125,000$.

20. Regional Setting Area is on W flank of Toquima Range (generally W-tilted) and occurs as erosional "window" beneath Tertiary volcanic rocks (on S) exposing oes 1 and intrusive contact with granitic rocks of probable Cretaceous age (Kleinhampl and Ziony, unpublished manuscript (1978)).

21.' Faults No large-scale faults observed. Several small, outcrop-size faults of small displacement (generally low $S$ dip) observed.

22. Joints Generally show high degree of fracturing; no uniform orientation noted.

23. Folds Some open-to-close folds, generally showing $S$ or SW plunge were observed in calcareous slate \& limestone. Phyllites show some crenulation folds when exposed suggesting considerable internal deformation.

24. Topography Occurs in low hills on $W$ margin of Toquima Range; continues to $W$ as isolated monadnocks on pediment flanking Big Smoky Valley.

25. Slopes, max-min Generally to $\mathrm{W},-40 \%-12 \%\left(7^{\circ}-22^{\circ}\right)$ Estimated Avg =-

26. Ridge gradients -Lengths --

27. Stm gradients All intermittent-4-8\% $\left(4.6^{\circ}-2.3^{\circ}\right)$ generally W Channel width Generally $<15$ m $\left(50^{\prime}\right)$

28. Dist.-brng to major topo break Lies on break between Toquimas Range \& Big Smoky Valley

29. Miscellaneous: Access rte From Jct NV 8A and US 6 (5 mi E of Tonopah), go N 42.5 mi on NV $8 \mathrm{~A}$ to dirt road following $\mathrm{E}-\mathrm{W}$ section boundary.

30. Known drill holes None noted.

31. Known springs None observed; one mapped (Round $\mathrm{Mt} 7-1 / 2^{\prime}$ ) near contact of $0 \theta_{\mathrm{p}}$ and $\mathrm{Kg}$.

32. Mines (active/abandoned) No active mines here; Smoky Valley Mining Co. open-pit gold operation is $-4 \mathrm{mi}$ NNW of locality.

33. Prospects/claims Several old prospects near TV-Oep and oep-Kg contact.

34. Mineralization/alteration Lòcally shows silicification and limonite stain.

35. Possible subsurf proj No clear fault to $W_{\text {; }}$ may underlie pediment for few miles.

36. Possible testhole sites --

37. Possible geophysical sites --

38. Other =- 
F IELD RECONNAISSANCE CHECKLIST

Phase II Investigations: Fine-Grained (fn/grn)

Clastic Sedimentary Rocks and Metamorphic

Derivatives in Eastern Nevada
Locale Designation $\mathrm{NN}-1 \mathrm{~F}$

Sublocale Name Jefferson Canyon

1. Stratigraphic name/ designator Palmetto Fm (oep)

2. Unit above: $1 \mathrm{ith} /$ thick Esmeralda Fm (TV) Rhyolitic to intermediate tuffs overlain in Toiyabe Range to W by Diablo Fm (Pd) (coarse clastics). not exposed here. Also overlain in part by other TV including Oddie rhyolite and undifferentiated volcanics.

3. Unit below: 1ith/thick Gold Hill Fm (eg) quartzite \& lesser schist.

4. Topo maps : $1^{\circ} \times 2^{\circ}$ Tonopah $15^{\prime}=-7-1 / 2^{\prime}$ Round Mtn

5. Other = Sec Not surveyed Twaship =-_ Range =-..

6. Distr-Brng 150-1700 m (500-5500') S78E from Confluence of Jefferson \& Ink House Canyons.

7. Exp area \& dimensions $-5.4 \mathrm{~km}^{2}\left(3.4 \mathrm{mi}^{2}\right)$ \%edrock exp Up to 50 in canyon walls; much less out of canyon. Area is $-4.0 \mathrm{~km}(\mathrm{~N}-\mathrm{S})$ by $3.2 \mathrm{~km}$ wide $(\mathrm{E}-\mathrm{W})(2.5 \times 2.0 \mathrm{mi})$, reduced somewhat by anticlinal "core" of eg.

8. Stratigraphy (Estimated By foot traverse Measured =-

9. Unit-thickness exp? Fn-grn\% Perhaps 50 Clay-mineral rich \% Probably none.

10. Lat continuity Poor; highly deformed Induration and Colors Generally buff weathering, gray to black. Mostly hard, brittle.

11. Thickness-clay horizon Cannot be estimated because of deformation.

12. Samples \& locations None

13. Other Lithologies Unit here is interbedded calcareous slates, phyllite and limestone. Slates are generally $\mathrm{fg}$ and dark gray, phyllites generally lighter and limestones bluish gray. All are very tightly folded on both outcrop and hand sample scale.

14. "Bedding" Average foliation (bedding?) attitude: $50^{\circ}, 35^{\circ} \mathrm{NW}$, but there is extensive deviation from this due to folding \& faulting.

15. Fiss1/Cleavage/Foliation Rocks (except limestones) show wel1-developed slaty to phyllitic foliation.

16. Contacts/Boundaries Base With $6 \mathrm{~g}$ disturbed by minor faulting; poorly exposed.

17. Top Overlain unconformably by Esmeralda Fm (TV).

18. Other Fault contact (down on NE) with undifferentiated TV to NE.

19. Structure. Best map reference Ferguson and Cathcart (1954). "Geologic Map of the Round Mountain Quadrange, Nevada," USGS GQ-40; also on Kleinhampl and Ziony (1967). "Preliminary Geologic Map of Northern Nye County, Nevada." These two maps differ considerably in this area. Differences were not reconciled, but Ferguson \& Cathcart appears to be less detailed.

20. Regional Setting This portion of Toguima Range is due primarily to volcanic accumulation (Tertiary) and plutonic granitic intrusion (Tertiary-Cretaceous) with Paleozoic strata showing deformation and metamorphism probably temporally associated with granitic intrusion and associated regional metamorphism. 
FIELD RECONNAISSANCE CHECKLIST (cont)

Locale Designation $\mathrm{NN}-1 \mathrm{~F}$

Sublocale Name Jefferson Canyon

21. Faults NW-striking fault mapped between PZ rocks and TV on NE edge of area. Thrust fault mapped by Kleinhampl between $O_{p}$ and $e g$ not observed.

22. Joints Rocks highly fractured; uniform orientation not observed.

23. Folds Folds are tight to isoclinal, fold axes vary considerably, and folds are often disharmonic, particularly between different rock types. Axial surfaces of folds roughly coincide with foliation attitude (Item 14). As shown by Ferguson \& Cathcart (1954) area is a broad NW-plunging anticline cored by $E g$ on SE. This structure is not indicated on map by Kleinhampl and Ziony (1967).

24. Topography Exposures are in low hills on $W$ edge of Toquima Range. Ink House \& Jefferson Canyons are incised $-10 \mathrm{~m}\left(30^{\prime}\right)$ giving good exposures.

25. Slopes, max-min Generally to $W, 50 \%-16 \%\left(27^{\circ}-9^{\circ}\right)$ Estimated Avg =-

26. Ridge gradients =Lengths $=$

27. Stra gradients Jefferson Canyon $-5 \%\left(2.7^{\circ}\right)$ to W; Ink House Canyon $6.5 \%\left(3.8^{\circ}\right)$ to SW. Channel width Jefferson- $90 \mathrm{~m}\left(300^{\prime}\right)$; Ink House- $-30 \mathrm{~m}\left(100^{\prime}\right)$

28. Dist.-brng to major topo break Exposures lie approximately on boundary between Toguima Range and Big Smoky Valley to $W$.

29. Miscellaneous: Access rte From Jct NV 8A and US 6 (5 mi E of Tonopah), go N 48 mi to Round Mt turnoff. Turn E $2.3 \mathrm{mi}$ and bear left staying $\mathrm{N}$ of Round Mt (cemetery on left). Road follows contours on pediment-fan $-1.7 \mathrm{mi} N \mathrm{NE}$ then bears $\mathrm{E}$ up Jefferson Canyon. Continue $\sim 1.0 \mathrm{mi}$ up canyon until bedrock outcrops of oep encountered.

30. Known drill holes None noted.

31. Known springs None noted. Area dissected by Jefferson Canyon with perennial stream which is probably in part spring-fed. Ink House Spring is mapped in Ink House Canyon on NE edge of area where $0 € p$ is in probable fault contact with TV.

32. Mines (active/abandoned) No present activity except at Round Mt, $2-1 / 2 \mathrm{mi}$ to SW. Several abandoned shafts are mapped within outcrop over near TV contact on NE. One shaft mapped at Jefferson Cyn-Ink House Cyn confluence in " $Q 91$. " $01 d$ mining town of Jefferson (primarily Au) is $\sim 1.5 \mathrm{mi}$ E of area.

33. Prospects/claims None noted but shafts are old enough to probably be patented claims.

34. Mineralization/alteration Contains locally developed silicified zones, usually best developed near zones of lithologic contrast, probably related to ductility contrast and resultant differences in structural behavior (i.e., small-scale faulting).

35. Possible subsurf proj Probably extends some unknown distance to w under valley pediment.

36. Possible testhole sites =-

37. Possible geophysical sites =-

38. Other Round Mt mine operated by Smoky Valley Mining Co.

Geologist J. Connolly Organization UNM Date $5 / 19 / 79$ 
F IELD RECONNAISSANCE CHECKLIST

Phase II Investigations: Fine-Grained (fn/grn)

Clastic Sedimentary Rocks and Metamorphic

Derivatives in Eastern Nevada
Locale Designation NN-1G

Sublocale Name Meadow Canyon

1. Stratigraphic name/

designator Palmetto Fm (oep) (of Ferguson \& Cathcart, 1954); equivalent to oesl of

Kleinhampl and Ziony (1967).

2. Unit above: 1 ith/thick Permian clastics ( $P c$ ) not obs. in depos. contact; unconformably overlain by Jefferson Tuff and other Tertiary volcanics (TV).

3. Unit below: 1ith/thick Gold Hill Fm (eg); quartzite \& quartzose micaschist; $\sim 5000^{\prime}$

4. Topo maps: $1^{\circ} \times 2^{\circ}$ Tonopah $15^{\prime}=$ 7-1/2' Corcoran Canyon

5. Other -Sec NWl $/ 4 \operatorname{Sec} 1$ Twnship $9 \mathrm{~N}$ Range 45E

6. Distr-Brng -from --

7. Exp area \& dimensions $32 \mathrm{~km}^{2}\left(12.5 \mathrm{mi}^{2}\right)$ \%Bedrock exp Less than 5. Most exposure locally derived float. Area is generally crescent-shaped convex to NE, long dimension (NW) $-11 \mathrm{~km} \times 1.6-4.8 \mathrm{~km}(7 \times 1-3 \mathrm{mi})$ in $\mathrm{NE}$ direction.

8. Stratigraphy (Estimated By foot traverse Measured --

9. Unit-thickness exp Cannot be estimated here Fn-grn\% May be high (see Item 13) Clay-mineral rich \% Probably none

10. Lat continuity? Induration and Colors Hard, slaty, gen. bluish gray.

11. Thickness-clay horizon Probably no clay.

12. Samples \& locations None

13. Other Lithologies Only rock type observed was bluish gray, noncalcareous, platy to fissile hard slate showing local development of pyrite cubes, up to $1 \mathrm{~mm}$.

14. "Bedding" None observed. A11 outcrops are rubble-float covered.

15. Fissl/Cleavage/Foliation Rock shows wel1-developed slaty cleavage; relation to bedding unknuwu. Rocks in this area tend to be of lower metamorphic (textural) grade than those in other outcrop areas. All other areas are bordered closely by $\mathrm{Kg}$, whereas this area is $3.2-4.8 \mathrm{~km}(2-3 \mathrm{mi})$ from nearest $\mathrm{Kg}$ outcrop, suggesting a genetic relationship between $\mathrm{Kg}$ and the more phyllitic grades of metamorphic rocks derived from 06p.

16. Contacts/Boundaries Base Not observed. Kleinhampl \& Ziony (1967) show depos. \& fault with $\theta 8$

17. Top Uncomformably overlain by TV and intruded by related dikes.

18. Other Intruded by Cretaceous (?) granitic rocks ( $\mathrm{Kg}$ ) on $\mathrm{S}$ margin of area.

19. Structure. Best map reference Kleinhampl and Ziony (1950). "Preliminary Geologic Map of Northern Nye County, Nevada," USGS Open File Map.

20. Regional Setting Area is $1.6 \mathrm{~km}$ (1 mi) NW of range marginal fault on $E$ side of $T$ oquima Range, which is generally W-tilted. "Main" range margin fault probably lies under alluvium of Monitor Valley. Outcrops of oep are exposed chiefly beneath cover of younger volcanic rocks. Local dikes are common, and area is in intrusive contact with $\mathrm{Kg}_{\mathrm{g}}$ on southern margin of exposure area. 
FIELD RECONNAISSANCE CHECKLIST (cont)

Locale Designation $\mathrm{NN}-1 \mathrm{G}$

Sublocale Name Meadow Canyon

21. Faults None observed in area except minor one between TV \& intrusive dikes and oep. Has NE strike; exposures are poor.

22. Joints None observed because of poor outcrop

23. Folds None observed because of poor outcrop. Prob internally folded with development of . slaty cleavage. Mapped attitudes (K\&Z, 1967) generally dip to NE 4000' to SW.

24. Topography Area observed is in SE drainage of Meadow Canyon. Surrounding exposures are in generally gentle mountainous terrain with locally steep hills. Elev. 2200-2400 m $\left(7200-8000^{\prime}\right)$.

25. Slopes, max-min Average slopes, $50 \%-28 \%\left(27^{\circ}-16^{\circ}\right)$ Estimated Avg Mostly 1ow end, hills on high end

26. Ridge gradients -Lengths =-

27. Stm gradients Meadow Canyon $2.7 \%\left(1.5^{\circ}\right)$ to SE Channel width $30-120 \mathrm{~m}(100-$ $\left.400^{\prime}\right)$; channel is wider when in $0 \theta_{p}$ than in TV, 15-30 m (50-100').

28. Dist.-brng to major topo break $-1.6 \mathrm{~km}(1.0 \mathrm{mi})$ to fault with $\mathrm{TV}$ and pediment on NW edge of Monitor Valley

29. Miscellaneous: Access rte From Jct NV 8A and US 6 (5 mi E of Tonopah). Go N on NV 8A 13 mi to Belmont turnoff (NV 82). Proceed NE on NV $8228 \mathrm{mi}$ to Belmont. Continue approx past Belmont (SE then NE) $\sim 5.1 \mathrm{mi}$ to Jefferson Summit turnoff. Continue NW $\sim 3.6$ mi up Meadow Canyon. Oep outcrops near area of two abandoned buildings on NE side of canyon.

30. Known drill holes None observed.

31. Known springs None observed. Meadow Canyon occupied by perennial stream probably spring-fed

32. Mines (active/abandoned) None

33. Prospects/claims None in area. To NW area E of Jefferson Sumit; staked very recently in TV

34. Mineralization/alteration Minima1. Relict pyrite cubes common in slate, largely altered. Probably of synmetamorphic orgin.

35. Possible subsurf proj May underlie TV in part; extent unknown.

36. Possible testhole sites --

37. Possible geophysical sites =-

38. Other --

Geologist J. Connolly Organization UNM Date $5 / 18 / 79$ 
FIELD RECONNAISSANCE CHECKLIST

Phase II Investigations: Fine-Grained (fn/grn)

Locale Designation NN-2A

Clastic Sedimentary Rocks and Metamorphic

Derivatives in Eastern Nevada

Sublocale Name S Tip of Hot Creek Range (Warm Spr NW)

1. Stratigraphic name/

designator Eleana $\mathrm{Fm}$ (Me)

2. Unit above: 1ith/thick Tertiary andesite flows \& younger tuffs (not observed this locale (TV)).

3. Unit below: 1 ith/thick ? In fault contact with all older units per kleinhampl \& Ziony (1967).

4. Topo maps: $1^{\circ} \times 2^{\circ}$ Tonopah $15^{\prime}=$ 7-1/2' Warm Springs NW

5. Other -Sec $=-$ Twnship =Range --.

6. Distr-Brng 5000' S45W from Unsurveyed intersection T4N\& T5N \& E edge of Warm Springs NW $7-1 / 2^{\prime}$ guad (1ong. $116^{\circ}, 22^{\prime}, 30^{\prime} '$ ).

7. Exp area \& dimensions $-1.6 \mathrm{~km}^{2}\left(0.6 \mathrm{mi}^{2}\right)$ \%Bedrock exp 10-20; many slopes covered by colluvial veneer. Area dimension $\sim 1.6 \mathrm{~km}$ long (NW) by $0.9 \mathrm{~km}$ (NE) $(1 \times 0.6 \mathrm{mi})$.

8. Stratigraphy (Estimated By foot traverse. Me asured $=-$

9. Unit-thickness exp $-120-150 \mathrm{~m}\left(400-500^{\prime}\right)$ Fn-grn\% Perhaps 70 Clay-mineral rich \% Unknown Argillite is perhaps $40 \%$ (vs siltstones) of Me but clay min composition unknown. Hardness suggests argillite is highly silicious.

10. Lat continuity Evidence of internal deformation suggests this not good. Induration and Colors Hard, brittle; light gray to dark gray, rarely buff.

11. Thickness-clay horizon Unknown. Outcrop too poor to estimate.

12. Samples \& locations None taken.

13. Other Lithologies Me exposed is estimated to be approximately equal amounts of silicious argillite-shale and calcareous siltstone-fn grn sandstone with subordinate lenses of limestone. Limestone lenses may be in part stratigraphic, but the present configuration is tectonic in origin.

14. "Bedding" N50W, 70SW in limy siltstone. Dips are generally to SW but are highly variable.

15. Fiss1/Cleavage/Foliation Argillite \& shale tend to be highly fissile. Calcareous siltstones and limestones are not.

16. Concacts/Buundaries Bace Strat. hase not exposed; fault contact with Silurian-0rdovician limestones and dolomites as shown by Kleinhampl and Ziony (1967).

17. Top Thrust fault contact with Mississippian Limestone on $\mathrm{S}$ margin of area.

18. Other =-

19. Structure. Best map reference Kleinhampl and Ziony (1967). "Preliminary Geologic Map of Northern Nye County, Nevada," USGS Open File Map.

20. Regional Setting Area lies on E margin of Southern Hot Creek Range, an internally faulted, fault-block range of NNE trend. Locale is bounded on north by WNW-striking high-angle fault with Sil-ord dolomite $\&$ on S by SW-dipping thrust contact with Mississippi Limestone. W boundary is unconformable with TV, but Me exposures appear to wedge in this direction. E boundary is with $Q$ al and inferred fault on Range margin. 
FIELD RECONNAISSANCE CHECKLIST (cont)

Locale Designation $\mathrm{NN}-2 \mathrm{~A}$

Sublocale Name S Ti Of Hot Creek Range (Warm Spr NW)

21. Faults Thrust fault on $S$ shows folds in upper plate suggestive of NE transport. Numerous outlines and inclusions of folded limestone in Me suggest much internal synthetic faulting related to this thrust fault. Me occupies lower plate position of thrust but as suggested by Kleinhample \& Ziony (1967) is in upper allochthonous sequence in the Hot Creek Range.

22. Joints Exposures show a high degree of fracturing but uniform orientation not noted.

23. Folds Tight-to-close folds are abundant in Me; shale tends to occur in tectonic "pods" infolded into stronger limy siltstone and argillite; folds prob. related to thrusting.

24. Topography Area of low to moderate hills SW of gap through sharp ridge related to WNWstriking high-angle fault with dolomites.

25. Slopes, max-min In Me, 33\%-20\% $\left(18^{\circ}-11^{\circ}\right) \quad$ Estimated Avg Range given previously

25. Ridge gradients Limestone lenses \& sandstone lenses form NW-striking small ridges. Slopes in range above.

Lengths Max $\sim 150 \mathrm{~m}\left(500^{\circ}\right)$

27. Stm gradients 2 intermittent stms $-\mathrm{N} 4 \%\left(2^{\circ}\right)$ to $E$; S $4.5 \%\left(2.5^{\circ}\right)$ to $\mathrm{E}$.

Channel width Both 61-122 m (200-400')

28. Dist.-brng to major topo break $-900 \mathrm{~m}\left(3000^{\prime}\right)$ due E to pediment alluvial fan complex sloping $-10 \%\left(6^{\circ}\right)$ ESE to Reveille Valley.

29. Miscellaneous: Access rte From Warm Springs (Jct US 6 \& NV 25) proceed NE on US $62.3 \mathrm{mi}$. Unmaintained dirt trail leads NW $\sim 2.7 \mathrm{mi}$ (keep to left on one fork) through gap caused by NW-striking ridge of dolomite. Me outcrop area is between this ridge and limestone ridges to SW.

30. Known drill holes None noted

31. Known springs Milk Spring is mapped $1800 \mathrm{~m}\left(6000^{\prime}\right)$ N55W from locale. Hot spring at Warm Springs (probably $\sim 50^{\circ} \mathrm{C}$ ) is $\sim 5 \mathrm{~km}(3 \mathrm{mi}) \mathrm{S} 15 \mathrm{E}$ of locales.

32. Mines (active/abandoned) None noted

33. Prospects/claims None noted

34. Mineralization/alteration Silicification is pervasive throughout sequence and limestones are very highly recrystallized. Red stain silicification along fault on $N$ edge.

35. Possible subsurf proj None outside area. Faults on $N, S \& E$. Wedge between faults probable to $W$.

36. Possible testhole sites =-

37. Possible geophysical sites --

38. Other =-

Geclogist J. Connolly Organization UNM Date $5 / 19 / 79$ 
F IELD RECONNAISSANCE CHECKL IST

Phase II Investigations: Fine-Grained (fn/grn)

Locale Designation $\mathrm{NN}-2 \mathrm{~B}$

Clastic Sedimentary Rocks and Metamorphic

Derivatives in Eastern Nevada

Sublocale Name Empire-

Keystone Canyon Divide

1. Stratigraphic name/

designator Elezna $\mathrm{Fm}(\mathrm{Me})$

2. Unit above: 1ith/thick Penn-Permian Sedimentary Rocks ( $P \mathbb{P s}$ ); coarse to fg clastics; not in depositional contact with Me in area; is unconformably overlapped (with angular

discordance) by tuff of Hot Creek Canyon (Theu and Thc1); this is pumiceous sanidine rich welded tuff, locally up to $610 \mathrm{~m}\left(2000^{\prime}\right)$ thick.

3. Unit below: lith/thick Nevada Fm (Dn); highly recryst gray limestones unconf overlies Me in Empire Canyon.

4. Topo maps: $1^{\circ} \times 2^{\circ}$ Tonopah 15' Tybo 7-1/2' Flagstaff Mt

5. Other =Sec -Twnship =Range =-

6. Distr-Brng $1800 \mathrm{~m}\left(6000^{\prime}\right) \mathrm{N} 52 \mathrm{E}$ from Cine Mountain (elev. 7740')

7. Exp area \& dimensions This is S portion of contiguous area of which Keystone-01d Dominion sublocality is northern part. Areas are separated by Keystone Canyon drainage that contains thin colluvial veneer developed on Me. All area included with Keystone-01d Dominion sublocale.

\%Bedrock exp 15; much sandstone float

8. Stratigraphy (Estimated From foot traverse Measured --

9. Unit-thickness exp $2460 \mathrm{~m}\left(1500^{\prime}\right)$ Fn-grn\% Perhaps 60 clay-mineral rich \% Perhaps 30

10. Lat continuity Cannot be estimated due to poor exposures.

Induration and Colors Dark gray, weathering brown to light gray. Usually brittle at surface exposures.

11. Thickness-clay horizon Same as Item 10 .

12. Samples \& locations Nume taken--08s Keystnne-0ld Dominion locale.

13. Other Lithologies Predominant exposed lithologies are vfg sandstones (quartzitic to lithic sandstones) \& siltstones in lenses \& tabular (?) beds $1-10 \mathrm{~m}$ thick. Prominent in upper part (flanks of syncline) are very coarse to conglomeratic lithic (cherty debris) sandstones, in lenses up to $10 \mathrm{~m}$ thick.

14. "Bedding" Very coarse lithic sandstone and sh: N20E, 35W; mapped attitudes (Quinlivan \& Rogers, 1974) show considerable variation; N10E, vert-sandstone lens.

15. Fissl/Cleavage/Foliation Me argil1ite shows a we11-developed platy cleavage. Rough concordence with lenses of other lith suggest this is a bedding fissility.

16. Contacts/Boundaries Base Depos. contact mapped by Quinlivan \& Rogers (1974) in Empire Canyon to S (not observed). Unconformably overlain by tuff of Hot Creek Canyon (Thcu) on W side of valley.

17. Top $=$

18. Other Exposure area is usually fault-bounded by $\mathrm{Dn}$ on $\mathrm{E}$ and by volcanics on W. 
FIELD RECONNAISSANCE CHECKLIST (cont)

Locale Designation NN-2B

Sublocale Name Empire-Keystone Canyon Divide

19. Structure. Best map reference Quinlivan and Rogers (1974). "Geologic Map of the Tybo Quadrangle, Nye Co., Nevada," USGS Misc. Inv. Map I-821.

20. Regional setting Area lies in a fault-bounded structurally low area within the very generally w-tilted and internally faulted Hot Creek Range. Structural consideration \& present relief of rock units (as shown by Quinlivan and Rogers, 1974) suggest the Me-Dn-PPs sequence may be in the lower plate of a regional thrust with Silurian-0rdovician in upper plate. This geometry (if present) has been highly modified by Mid-Tertiary volcanism \& high-angle faulting.

21. Faults Numerous NNE-trending high-angle faults (mostly down to $W$ on $W$, down to $E$ on $E$ ) cut area. Displacements appear to be relatively small $(<30 \mathrm{~m})$ also, curved fault traces in map view suggest possible flattening at depth \& perhaps gravity slide origin.

22. Joints Exp sandstones are highly fractured but poor exposures make quantitative estimate impossible.

23. Folds Area mapped on broad NNE-trending syncline, but small-scale folds not observed due to poor exposures.

24. Topography Me is exposed in small NNE-SSW intermontane valley characterized by low hills with steep slopes to mountainous area on $E$ and $W$

25. Slopes, max-min $23 \%-14 \%\left(13^{\circ}-8^{\circ}\right)$. Steeper slopes are on $\mathrm{E}$ side of area. Estimated Avg $19 \%\left(10.5^{\circ}\right)$

26. Ridge gradients Are included in slope gradients Lengths Ridges slope toward axis of area at very slightly higher gradients than drainage.

27. Stm gradients $14 \%-8 \%\left(8^{\circ}-5^{\circ}\right)$ to $\mathrm{S}$ Channel width Gradients are for tributary stream draining south into Empire Canyon. Gradient for Empire Canyon is $2.5 \%$ $\left(1.5^{\circ}\right)$ to E. Tributary channels are a few metres wide; Empire Canyon is 60 to $100 \mathrm{~m}$ wide.

28. Dist.-brng to major topo break =-

29. Miscellaneous: Access rte From Warm Springs, go $9.6 \mathrm{mi}$ E on US 6. At US Navy "Base Camp" turn NW on we11-graded dirt road. At Tybo Fork $(-4 \mathrm{mi})$ bear $N$ (right) and continue 7.1 mi to Keystone Turnoff. Turn $W$ toward Keystone and continue up canyon past spring ( $2.7 \mathrm{mi}$ from turn) $-4.3 \mathrm{mi} \mathrm{W}$ up canyon until canyon opens into $\mathrm{N}-\mathrm{S}-\mathrm{t}$ rending valley. Bear $1 \mathrm{eft}$ (SW) second left turnoff and continue $S W$ in valley 2.2 mi to drainage divide. Me outcrops in valley, covered by alluvium in lower parts.

30. Known drill holes None observed

31. Known springs No springs noted and none mapped on Flagstaff Mt Quadrangle in Me area.

32. Mines (active/abandoned) Some inactive prospects in $S$ part of area in Empire Canyon.

33. Prospects/claims Scattered old claim stakes are present.

34. Mineralization/alteration Minimal away from faults on margin of area. (See Keystone-0ld Dominion locale.) 
F IELD RECONNAISSANCE CHECKLIST (cont)

Locale Designation NN-2B

Sublocale Name Empire-Keystone Canyon Divide

35. Possible subsurf proj Much of valley apparently underlain by Me and volcanics may be underlain by Me at shallow depth on west.

36. Possible testhole sites --

37. Possible geophysical sites =-

38. Other -- 
FIELD RECONNAISSANCE CHECKLIST

Phase II Investigations: Fine-Grained ( $f n / g r n$ )

Clastic Sedimentary Rocks and Metamorphic

Derivatives in Eastern Nevada
Locale Designation $\mathrm{NN}-2 \mathrm{C}$

Sublocale Name Keystone-01d

Dominion Canyon Divide

1. Stratigraphic name/

designator Eleana $\mathrm{Fm}$ (Me)

2. Unit above: lith/thick Penn-Permian Sed Rocks ( $P \mathbb{P S}_{S}$ ); coarse to fine clastics; not in depos. contact with Me in area.

3. Unit below: 1ith/thick Nevada Fm (Dn); highly recryst gray limestone.

4. Topo maps: $1^{\circ} \times 2^{\circ}$ Tonopah $15^{\prime}$ Tybo $15^{\prime}$ $7-1 / 2^{\prime}$ Flagstaff Mt

5. Other =- Sec

6. Distr-Brng $3500 \mathrm{~m}\left(11600^{\circ}\right) \mathrm{N} 40 \mathrm{~W}$

from Keystone Spring

7. Exp area \& dimensions $13 \mathrm{~km}^{2}\left(5.2 \mathrm{mi}^{2}\right)$. Area includes all Me outcrops between 01d Dominion Empire Canyons (both subareas). This estimate of area includes $2.4 \mathrm{~km}^{2}\left(1.5 \mathrm{mi}^{2}\right)$ mapped as alluvium-colluvium by Quinlivan and Rogers (1974). Area is maximum $2400 \mathrm{~m}$ ( $8000^{\prime}$ ) to minimum $970 \mathrm{~m}\left(3200^{\prime}\right)$ wide in WNW direction and $2500 \mathrm{~m}\left(28000^{\prime}\right)$ long in NNE direction. \%Bedrock exp 10 or less; extensive sandstone float.

8. Stratigraphy (Estimated From several walking traverses. Measured --

9. Unit-thickness exp $\sim 460 \mathrm{~m}\left(1500^{\prime}\right) \quad$ Fn-grn\% $\sim 50$ Clay-mineral rich $\% \simeq 20$

10. Lat continuity Cannot be estimated due to poor exp \& fault boundary. Induration and Colors Dark gray, weathers light gray. Generally hard \& brittle at surface.

11. Thickness-clay horizon Same as Item 10 .

12. Samples \& locations NN2-OD1: along trail leading NE from main trail between Keystone \& 01d Dominon Canyons $\sim 7-1 / 2 \mathrm{mi} \mathrm{N}$ of Keystone Canyon

13. Other Lithologies Include mostly vfg quartzite (locally up to $10 \%$ lithic fragments), \& quartzose siltstone. Both generally pale gray. These rock types dominate the float on Me, but shale expusiures arc common and suggest that shale dominates the sequence. Interbedded thin sandstones are mostly quartzite while several thick lenses of subarkose or arkose (up to 50') are present. Best exposures are near the inferred upper part of the section near the fault contact with $\mathrm{Dn}$.

14. "Bedding" Shaley outcrop (dug-out) N85E, 36S; same: N37E, 47SE

15. Fiool/Cleavage/Fnliation Shale has well-developed platy cleavage breaking into platelets generally $2 \mathrm{~mm} \times 5 \mathrm{~mm}$.

16. Contacts/Boundaries Base Usually in fault contact with Dn. Depositional contact mapped by Quinlivan \& Rogers (1974) in Empire Canyon to S. Me is overlapped by Tert. volcanics but present contact is usually mapped as a fault.

17. Top $=$

18. Other =-

19. Structure. Best map reference W. D. Quinlivan and C. L. Rogers (1974). "Geologic Map of the Tybo Quadrangle, Nye Co., Nevada," USGS Misc. Inv. Map I-821. 
FIELD RECONNAISSANCE CHECKLIST (cont)

Locale Designation $\mathrm{NN}-2 \mathrm{C}$

Sublocale Name Keystone-01d Dominion Canyon Divide

20. Regional Setting Area lies in fault-bounded structurally low area within the very generally W-tilted \& internally faulted Hot Creek Range. Mapped area is crudely syclinal with NNW axis (Quinlivan \& Rogers, 1974).

21. Faults Several "alteration zones" observed correspond with high angle faults mapped. As mapped, these anastomose \& show a general NNW to NE strata \& are generally mapped with separations "down" to the $W$. arcuate map view suggestive of curved profile at depth are common \& suggest possible gravity slide origin.

22. Joints =-

23. Folds None observed on outcrop scale but wide variation in measured strata dip suggests internal folding is common.

24. Topography $\mathrm{Me}$ is exposed in small $\mathrm{N}$-trending intermontane valley and drainage divide between Keystone and 01d Dominion Canyon drainages. Area is characterized by steep slopes on $E \& W$ to mountainous terrain.

25. Slopes, max-min (E, $\left.17 \%\left(9^{\circ}\right) \mathrm{W}, 20 \%\left(11^{\circ}\right)\right)$ Estimated Avg $18.5 \%\left(10^{\circ}\right)$

26. Ridge gradients NA: area slopes rather uniformly as above. Lengths =-

27. Stm gradients W-draining intermittent: $19 \%\left(11^{\circ}\right)$ Channel width $\mathrm{N}-\&$ S-draining intermittent streams to major canyons: $7 \%\left(4.2^{\circ}\right)$. Major E drainage in Keystone and $01 d$ Dominion Canyons: $3.5 \%\left(2^{\circ}\right)$.

28. Dist.-brng to major topo break --

29. Miscellaneous: Access rte From Warm Springs go $9.6 \mathrm{mi}$ E on US 6. At US Navy "Base Camp" turn NW on well-graded dirt road. At Tybo fork $(-4 \mathrm{mi})$ turn $N$ (right fork) and continue $7.1 \mathrm{mi}$ to Keystone turnoff. Turn $\mathrm{W}$ toward Keystone \& continue past spring (2.7 mi from turn) $-4.3 \mathrm{mi}$ up canyon until road is in broad intermontane valley. Bear right \& continue $\mathrm{N} 1.6 \mathrm{mi}$ to drainage divide. Me outcrops in valley.

30. Known drill holes --

31. Known springs None noted

32. Mines (active/abandoned) Several abandoned mines and prospect pits are concentrated mostly

33. Prospects/claims along $\mathrm{Dn}_{\mathrm{M}} \mathrm{Me}$ contact that shows much alteration. Claim stakes are very old; no recent activity noted except for small mining operations along Me-Dn contact ( fault) or $N$ end of area.

34. Mineralization/alteration Chalcopyritic and pyritic alt. on fract. surfaces in sandstones and quartzites concentrated along fault on $E$ between $D n \&$ Me. Several isolated dikes are present in $M c, \&$ around these shale is somewhat metamorphosed \& phyllitic \& sandstones are brecciated with interclast space filled with dark reddish-brown quartz (?). Liesegang banding is locally prominent in quartzites \& siltstones. 
F IELD RECONNAISSANCE CHECKLIST (cont)

Locale Designation NN-2C

Sublocale Name Keystone-01d Dominion Canyon Divide

35. Possible subsurf proj Me appears to underlie most of area; fault-bound on $E$ \& $W$ suggest no continuity to $\mathrm{E}$ but Me may be present under tuff to $\mathrm{W}$ if faulting is relatively minor.

36. Possible testhole sites --

37. Possible geophysical sites --

38. Other --

Geologist J. Connolly

Organization UNM

Date $6 / 18 / 79$ 
FIELD RECONNAISSANCE CHECKLIST

Phase II Investigations: Fine-Grained (fn/grn)

Locale Designation $\mathrm{NN}-2 \mathrm{D}$

Clastic Sedimentary Rocks and Metamorphic

Derivatives in Eastern Nevada

Sublocale Name Squaw Hills

1. Stratigraphic name/

designator Eleana Fm (Me)

2. Unit above: lith/thick Rhyolite flows and tuff (TR)

3. Unit below: 1ith/thick Nevada Fm; dolomite \& limestone; base not exp. (Dn)

4. Topo maps: $1^{\circ} \times 2^{\circ}$ Tonopah $15^{\prime}$ Moores Station \& Pritchards Station

7-1/2' At corner of Red King Mt, Chaos Creek \& Moores Station.

5. Other Parts of area in Secs $9,10, \mathrm{NE} 1 / 416, \mathrm{Nl} / 215, \mathrm{~T} 10 \mathrm{~N}, \mathrm{R} 52 \mathrm{E}$.

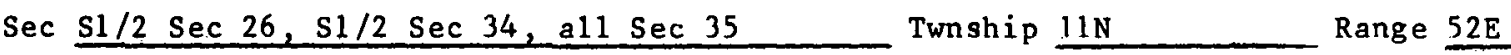

6. Distr-Brng =- from -

7. Exp area \& dimensions $6.5 \mathrm{~km}^{2}\left(2.5 \mathrm{mi}^{2}\right)$. Max dimensions $\mathrm{N}-\mathrm{S}: \sim 3.4 \mathrm{~km}(2.1 \mathrm{mi})$; E-W varies from $2.1 \mathrm{~km}$ to $2.9 \mathrm{~km}(1.3 \mathrm{mi}$ to $1.8 \mathrm{mi})$.

\% Bedrock exp $\sim 30-40$; sandstone float covers much of rest.

8. Stratigraphy (Estimated By foot traverse. Measured --

9. Unit-thickness exp $\simeq 210-240 \mathrm{~m}\left(700-800^{\prime}\right) \quad$ Fn-grn\% 40 from Item 13; $\sim 30$ Clay-mineral rich \% No clay shale. Argillite is clay rich.

10. Lat continuity Unknown; poor exposure Induration and Colors Med gray to buff tan, weathering brown, yellow, pale gray.

11. Thickness-clay horizon? Exposures are poor. Sequence dominated by coarser clastics.

12. Samples \& locations None taken.

13. Other Lithologies Qzite: $-40 \%$; conglo \& con sdst $20 \%$; siltite $\sim 20 \%$; argillite and shale $\sim 20 \%$. Dominant exposed 1 ithology is a $\mathrm{fg}$ buff-to-gray quartzite in tabular beds and large lenses $-1-20 \mathrm{~m}$ thick; conglomerate sandstone and granule to pebble conglomerate w mostly chert and nonquartzose lithic fragments (basaltic volcanic??) in lenses up to few meters thick; 1ight-gray siltite is poorly exposed except in float; argillite is exposed only in float and clay shale was not observed except as very rare float.

14. "Bedding" In fg qzite and siltite; NO ${ }^{\circ}, 43 \mathrm{E} ;$ parting in quartz sandstone: NO ${ }^{\circ}$, 40E; $\mathrm{N} 10 \mathrm{E}$, $60^{\circ} \mathrm{E}$ conglomeratic sandstone.

15. Fissl/Cleavage/Foliation Siltite \& argillite break into platelets and small slabs. All measured attitudes are bedding, but poor exposures preclude exam of shale fissility.

16. Contacts/Boundaries Base Not observed. Ekren and others (1973) show possible contact with Dn overlain by rhyolite lava and tuff (TR). Most places where Dn-Me contact is mapped, it is a fault--often a thrust with Dn in the upper plate.

17. Top Uncomformably overlain by Tertiary Volc (TR) that are apparently tilted to $N$.

18. Other Ekren \& others (1973) show fault boundary with other Tertiary volcanics to E along inferred margin of Williams Ridge cauldron.

19. Structure. Best map reference Ekren and others (1974). "Geologic Map of the Moore's Station Quadrange, Nye Co., Nevada," USGS Misc. Inv. Map I-756; also on Kleinhampl \& Ziony 
FIELD RECONNAISSANCE CHECKLIST (cont)

Locale Designation NN-2D

Sublocale Name Squaw Hills

(1967). "Preliminary Geologic Map of Northern Nye Co., Nevada." USGS open file map. Also see Dixon, G. L. and others, (1972). "Geologic Map of the Pritchards Station Quadrangle, Nye County, Nevada"; USGS Misc. Inv Map I-728.

20. Regional setting Area lies in $\mathrm{N}$ part of Hot Creek Range in Squaw Hills. Area is characterized by numerous nested caldera complexes and lies on the northern margin of the Hot Creek Valley \& Williams Ridge Caldrons.

21. Faults Several inferred faults of small displacement are mapped. To the SE, Me and Dn 1ie in the upper plate of a thrust over Williams Ridge Tuff (TWM). Kleinhamp1 \& Ziony (1967) show $M e$ and $D n$ in upper plate of thrust fault above Me. Me is in lower plate of thrust fault.

22. Joints Quartzites \& conglomerates show mod-spaced $(2-3 \mathrm{~m})$ fractures at high angle to bedding.

23. Folds NNW syclinal axis mapped (Ekren and others, 1973) in area. Internal deformation in quartzites not observed-appear to dip uniformly or traverse it to strike.

24. Topography Gentle mountainous area characterized by large rounded hills. Me forms fairly steep slopes throughout, suggesting shale not prominent lithology in sequence.

25. Slopes, max-min $50 \%-6 \%\left(27^{\circ}-3.6^{\circ}\right)$ Estimated $\mathrm{Avg} \sim 20^{\circ}$

26. Ridge gradients $50 \%-42 \%\left(27^{\circ}-23^{\circ}\right)$ Lengths Avg $\sim 370 \mathrm{~m}\left(1200^{\prime}\right)$

27. Stm gradients Avg $6 \%\left(3.6^{\circ}\right)$ Channel width $\sim 30 \mathrm{~m}\left(100^{\prime}\right)$

28. Dist.-brng to major topo break Outcrop on \& directly to $E$ of the highest ridge in the Confusion Hills-Squaw Hills topographic high.

29. Miscellaneous: Access rte $\sim 0.3 \mathrm{mi} \mathrm{N}$ of Moore's Sta., turn E proceed $4.0 \mathrm{mi}$ along Jumbled Rock Gulch, turn N $\sim 2 \mathrm{mi}$ along unmaintained Jeep trail. Not passable without 4WD.

30. Known drill holes None in area.

31. Known springs None observed in area; none mapped on quads.

32. Mines (active/ab andoned) None observed in area.

33. Prospects/claims None observed in area.

34. Mineralization/alteration Iron-oxide stain (sometimes as veinlets) is quite prominant locally on quartzites and siltites. Similar alteration is present in TR suggesting a genetic connection.

35. Possible subsurf proj =-

36. Possible testhole sites =-

37. Possible geophysical sites =-

38. Other Recent fault scarps cutting alluvium were observed in Hot Creek Valley just south of Moore's Station $\sim 5 \mathrm{mi} S W$ of this area. Similar scarps are present on the edge of $S$ and Springs Valley to $\mathrm{E}-3 \mathrm{mi}$ from area. Area is clearly seismically active. 
F IELD RECONNAISSANCE CHECKL IST

Phase II Investigations: Fine-Grained (fn/grn)

Clastic Sedimentary Rocks and Metamorphic

Derivatives in Eastern Nevada
Locale Designation $\mathrm{NN}-2 \mathrm{E}$

Sublocale Name Tybo Creek Area

1. Stratigraphic name/

designator Dunderberg Shale (ed)

2. Unit above: lith/thick Hales Limestone (Deh); thin-bedded to laminated gray limestone with minor shale \& sandstone; $2520 \mathrm{~m}\left(1700^{\prime}\right)$ mod. folded.

3. Unit below: $1 \mathrm{ith} /$ thick Swarbrick Fm (6s); thinly interbedded limestone \& chert, gray; $\sim 520 \mathrm{~m}\left(1700^{\prime}\right)$; strongly folded.

4. Topo maps: $1^{\circ} \times 2^{\circ}$ Tonopah $15^{\prime}$ Tybo 7-1/2' Tybo \& Flagstaff Mt

5. Other --

6. Distr-Brng $1200-1800 \mathrm{~m}\left(4000-6000^{\prime}\right)$ due $W$. Twnship =Range -T6N, R50E.

7. Exp area \& dimensions $3.1 \mathrm{~km}^{2}\left(1.2 \mathrm{mi}^{2}\right)$ \% Bedrock exp Avg 20 ; most covered by float from overlying $06 \mathrm{~h}$. Exposures are best in NE part of area. Area is $2400 \mathrm{~m}\left(8000^{\prime}\right)$ WNW by $1800 \mathrm{~m}\left(6000^{\circ}\right)$ NNE with overall area less due to anticlinal form (core in $e s$ ).

8. Stratigraphy (Estimated By foot traverse. Measured --

9. Unit-thickness exp $500 \mathrm{~m}\left(1500^{\prime}\right)$ (?). This is a "structural" thickness inferred from outcrop area but this is clearly due to thickening in core region of anticline. Strat. thickness probably no more than $200 \mathrm{~m}\left(600^{\prime}\right)$. Ed sample taken at Keystone sublocality. Fn-grn\% Perhaps 70 Clay-mineral rich \% Unknown

10. Lat continuity poor because of intense internal deformation.

Induration and Colors $\in d$ is slaty to weakly phyllitic, brittle to moderately soft. Greenish gray to gray.

11. Thickness-clay horizon?

12. Samples \& locations None

13. Other Lithologies Near base of Fm shales are subordinate to limestone $\alpha$ very calcareous. Calcareous shale and limestone lenses are present throughout interval but their extent is not determined.

14. "Bedding" Shows general northerly strike and highly variable (steep E or W to overturned) dips are indicative of internal folding.

15. Fissl/Cleavage/Foliation $€ d$ shales are highly fissile and tend to break \& weather into $2 \mathrm{~mm}$ chips in outcrop.

16. Contacts/Boundaries Base Generally gradation with es although contact shows minor faulting.

17. Top Overlain by $0 \theta h$, apparent $1 \mathrm{y}$ conformably although contact is often faulted.

18. Other Area fault bounded on $S$ ( $2 \mathrm{G}$ fault), a high-angle fault down to s juxtaposing es, ed, oeh sequence with younger limestones of Pogonip Group ( $O p$ ).

19. Structure. Best map reference Quinlivan and Rogers (1974). "Geologic Map of the Tybo Quadrangle, Nye Co., Nevada," USGS Misc. Inv. Map I-821. Complete Map Bibliog Ferguson, H. G. 
FIELD RECONNAISSANCE CHECKLIST (cont)

Locale Desigantion $\mathrm{NN}-2 \mathrm{E}$

Sublocale Name Tybo Creek Area

(1933). "Geology of the Tybo District, Nevada," NV Univ. Bulletin, V27, 3,61, \&. \& Kleinhamp1 \& Ziony (1967). "Preliminary Geologic Map of Northern Nye County, Nevada," USGS Open File Map, 1:200,000.

20. Regional Setting Area is located within $300 \mathrm{~m}\left(1000^{\prime}\right)$ of E edge of Hot Creek Range. Fault with Tert. volcanics (TV) mapped on range margin but line of springs suggest "master" fault of range lies 2 to $3 \mathrm{mi}$ farther E. Area is a highly deformed $\mathrm{N} 10^{\circ} \mathrm{E}$ trending, gent $1 \mathrm{y}$ plunging asymmetric to overturned (to E) anticline cored by $6 s$. Regional relations suggest the anticline may be related to position of rocks in lower plate of a regional thrust fault.

21. Faults W flank of anticline is mapped as fault between $\theta d$ and $\theta s$. High-angle faults tend to occur in 2 sets, one striking N10-20E, other $\sim$ N70W.

22. Joints Not observed in $\theta d$; abundant and irregularly developed in $\theta$ s.

23. Folds Not exposed in $6 d$ but thin-bedded limestone and chert of $\theta_{8}$ are tightly to isoclinally folded, somewhat disharmonically, with fold axes tending to show a northerly trend.

24. Topography Exposures are on $N \& S$ flanks of Tybo Creek. Terrain is mountainous with slopes in $\in d$ somewhat less than in more resistant oeh and $6 s$.

25. Slopes, max-min (In Ed (avg), 29\% $\left(16^{\circ}\right)$; in others (avg), $67 \%\left(34^{\circ}\right)$ "Pediment" of Hot Creek range E of area slopes to $W$.

Estimated Avg Range given previously.

26. Ridge gradients NA Lengths =-

27. Stm gradients Tybo Creek: $5.5 \%\left(3.1^{\circ}\right)$ Channel width Avg $150 \mathrm{~m}\left(500^{\prime}\right)$ in $G d$, 60-90 m (200-300') in other rock types.

28. Dist.-brng to major topo break Lies $\sim 300 \mathrm{~m}\left(1000^{\prime}\right) \mathrm{W}$ of Pediment of Hot Creek Range.

29. Miscellaneous: Access rte From Warm Springs, proc $9.6 \mathrm{mi}$ E on US 6. Turn NW at "Base Camp" (US Navy). Keeping to left, follow sign to Tybo $\sim 7 \mathrm{mi}$. Ed outcrops 1ie $2000^{\prime}$ $(\sim 0.4 \mathrm{mi})$ upstream from mouth of Tybo Canyon.

30. Known drill holes None noted, but probably present due to mining activity.

31. Known springs "Pedro" we11 lies on E edge of outcrop area; several mapped springs are present in Tybo area to $W$ and have supplied water to mining operations. Tybo Creek runs most of the year.

32. Mines (active/abandoned) Abundant historic mining activity within Tybo district (area is within district) prod.primarily $\mathrm{Ag}-\mathrm{Pb}-\mathrm{Zn}$ (Ferguson, 1933). District is presently inactive.

33. Prospects/claims Patented claims throughout district.

34. Mineralization/alteration Fault $w$ of area (between $\theta d-\theta s$ ) is deeply red-stained over areas 50-100' wide. Most historic production is along faults of this type. Local silicification and oxidation present within $6 d$.

35. Possible subsurf proj Probably underlies much of 0 hh to $W$ (X-Sect BB' of Quinlivan \& Rogers, 1974) below Tybo and to N of Tybo. 
FIELD RECONNAISSANCE CHECKLIST (cont)

Locale Desigantion NN-2E

Sublocale Name Tybo Creek Area

36. Possible testhole sites None: mine maps may yield subsurface information.

37. Possible geophysical sites =-

38. Other --

Geologist J. Connolly

Organization UNM

Date 5/19/79 
FIELD RECONNAISSANCE CHECKLIST

Phase II Investigations: Fine-Grained ( $\mathrm{fn} / \mathrm{grn}$ )

Clastic Sedimentary Rocks and Metamorphic

Derivatives in Eastern Nevada
Locale Designation $\mathrm{NN}-2 \mathrm{~F}$

Sublocale Name Keystone

1. Stratigraphic name/

designator Dunderberg Shale (Quinlivan \& Rogers, 1974) (6d).

2. Unit above: 1 ith/thick Hales Limestone, gray limestone, minor chert increasing clastics to top; $\sim 520 \mathrm{~m}\left(1700^{\prime}\right)$ (06h).

3. Unit below: 1 ith/thick Swarbrick Fm red to reddish brown chert \& limestone, minor shale; $-520 \mathrm{~m}\left(1700^{\prime}\right)$ strongly folded (6s).

4. Topo maps: $1^{\circ} \times 2^{\circ}$ Tonopah $15^{\prime}$ Tybo 7-1/2' Blue Jay Spring, Flagstaff Mt

5. Other -Sec -Twnship =Range --

6. Distr-Brng $1500 \mathrm{~m}$ (5000') N22E from Keystone Spring (Flagstaff Mt 7-1/2' Quad)

7. Exp area \& dimensions $9.3 \mathrm{~km}^{2}\left(3.6 \mathrm{mi}^{2}\right)$. Area $7.0 \mathrm{~km}(4.4 \mathrm{mi})$ long (NS) by 0.5 to $1.5 \mathrm{~km}$ ( 0.3 to $0.9 \mathrm{mi}$ wide) (EW). Only southernmost exposures observed in \% exposure estimate. This area same as E Hot Creek; E Hot Creek sublocale is the $\mathrm{N}$ edge. \%Bedrock exp =-

8. Stratigraphy (Estimated By traverse of area Measured $=$

9. Unit-thickness exp $\underline{-425 \mathrm{~m}\left(1400^{\prime}\right)}$ Fn-grn\% $\sim 90 \quad$ Clay-mineral rich \%? $\theta \mathrm{d}$ is slaty.

10. Lat continuity Appears good but includes thin lenses of non-shaley rocks as discussed below.

Induration and Colors Gray to dark gray; weathers greenish brown. Generally hard \& brittle.

11. Thickness-clay horizon =-

1.2. Samples \& locations NN-2--Key 1. From rel fresh exposures at road cut near adit used for storing blasting gel (see access route).

13. Other Lithologies Predominant other 1 ith. throughout is thin calcareous shale $\&$ siltstone that is present in generally thin beds. Lower part is limy \& gradational with Swarbrick Fm. Upper part grades by presence of thin limestone beds $(1 \mathrm{~cm}-1 \mathrm{~m}$ thick $)$ into Hales Limestone. Interbedded lithologies can be locally observed to pinchout within shale sequence.

14. "Bedding" Slaty cleavage (?) and/or bedding: N6W, $31 \mathrm{~W}$; in $6 \mathrm{~d} \sim 4 \mathrm{~m}$ W of dike: N27E 21W; interbedded lithologies indicate this is bedding. Quartz-siltstone lens in $6 \mathrm{~d}$ on $\mathrm{W}$ side of "anticline" N1OW, 44W; ind. sh \& calc. siltstone: N24E, 87E.

15. Fissl/Cleavage/Foliation Shale is very thinly fissile \& weathers to thin platelets. Rocks are always slaty and locally phyllitic.

16. Contacts/Boundaries Base Generally conformable with Swarbrick but discordance across contact suggests some slippage between two units.

17. Top Grades upward through thin limestone interbeds to Hales Limestone.

18. Other All units are intruded by dacite or rhyodacite dikes of $N$ trend. $G d$ and $G s$ are strongly folded adj to dikes sugg forcible intrusion; some dikes show very strong porphyllitic alteration of matrix. 
FIELD RECONNAISSANCE CHECKLIST (cont)

Locale Desigantion NN-2F

Sublocale Name Keystone

19. Structure. Best map reference Quinlivan, W. D. and Rogers, C. L. (1974). "Geol. Map of the Tybo Quadrangle, Nye Co., Nevada," USGS Misc. Inv. Map I-821.

20. Regional Setting Area lieg on E flank of Hot Creek Range, which is crudely W-tilted. Area is an internally deformed anticline formed in the sequence $6 w-\theta d-0 e h$, which plunges gent ly NlOW and is bounded by NlOW-striking high-angle fault with younger strata of the Pogonip Group, Nevada Fm and other Ordovician and Silurian Strata. Area is bounded on NE by gravity slide thrust block of Ordovician and younger strata. Area is bounded on SW by inferred fault contact with "older alluvium," which may in part be a pediment surface. The gravity slides postdate intrusion of Tertiary dikes.

21. Faults Border between ed \& es is locally a minor fault surface, \& a few E-W to ENE-WSW striking pre-dike faults cut across the area.

22. Joints ed shows abundant fractures at high angle to bedding. No systematic orientation noted.

23. Folds $\theta$ d is tightly folded, disharmonically adjacent to $\mathrm{N}$-trending dikes and shows some kink folding (view $N$ photo) with gently NlOW fold axes. Strike \& dip variations suggest much hidden internal folding.

24. Topography ed outcrop area is one of low to moderate $E$ sloping ridges and interveining canyons bordered by older terrace on $E$ and rugged mountians on $W$.

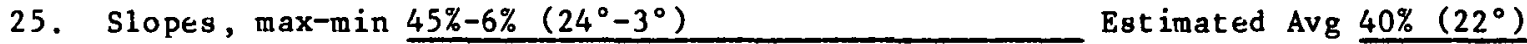

26. Ridge gradients $40 \%\left(22^{\circ}\right)$ Lengths =-

27. Stm gradients $6 \%\left(3^{\circ}\right)$ Keystone $C_{r} \quad$ Channe1 width $\simeq 130 \mathrm{~m}\left(400^{\prime}\right)$

28. Dist.-brng to major topo break Occurs at and just above contact with Hot Creek Valley alluvial fill.

29. Miscellaneous: Access rte US 6 9-3/4 mi NE of Warm Spr.; turn NW on Tybo Road $4 \mathrm{mi}$; bear right following signs to Keystone; at Keystone turn $N$ past active mine following graded road to old adit. BE CAREFUL--adit is powder magazine for mine.

30. Known drill holes Probably present due to exploration.

31. Known springs Keystone Spring lies on S edge of area in Keystone Canyon. Flows estimated to be on order of $30 \mathrm{gal} / \mathrm{min}$ from pipe.

32. Mines (active/abandoned) Numerous prospect pits are present and 8 to 10 abandonded adits \& shafts. Active mining operation ( $\mathrm{Ag}, \mathrm{Au}, \mathrm{Cu}, \mathrm{Pb}, \mathrm{Zn}$ ) is ongoing and has been operating since 1977 in Keystone townsite.

33. Prospects/claims Mine operator: Gold Creek Corp. (Einar C. Erickson) 2215 S. Fairfield, Las Vegas, NV 89102 .

34. Mineralization/alteration Propyllictic alteration of dikes \& vuggy guartz, Cu stain, silica boxwork (in limestones) adjacent to dikes and with border faults. 
RECONNAISSANCE CHECKLIST (cont)

Locale Desigantion NN-2F

Sublocale Name Keystone

35. Possible subsurf proj --

36. Possible testhole sites =-

37. Possible geophysical sites --

38. Other :-

Geologist J. Connolly

Organization UNM

Date $6 / 18 / 79$ 
FIELD RECONNAISSANCE CHECKLIST

Phase II Investigations: Fine-Grained (fn/grn)

Clastic Sedimentary Rocks and Metamorphic

Derivatives in Eastern Nevada
Locale Designation $\mathrm{NN}-2 \mathrm{G}$

Sublocale Name East Hot Creek (EHC)

1. Stratigraphic name/

designator Dunderberg Shale--6d (Tybo shale of Lowe11, 1965)

2. Unit above: lith/thick Hales Limestone (Gh)

3. Unit below: 1ith/thick Swarbrick Fm ( $G s)$; not exposed in this area.

4. Topo maps: $1^{\circ} \times 2^{\circ}$ Tonopah. Eastern edge of area is on E edge of Little Fish Lake 7-1/2' quad.

\section{$15^{\prime}$ Morey Peak}

5. Other --

6. Distr-Brng $1.6-3.4 \mathrm{~km}(1-2.1 \mathrm{mi}) \mathrm{N} 63 \mathrm{~W}$

7. Exp area \& dimensions $9.3 \mathrm{~km}^{2}\left(3.6 \mathrm{mi}^{2}\right)$.

\section{7-1/2' Hobble Canyon}

$\sec =$ Twnship -Range -$\sim 5$ but easy to locate area overlain by thin alluvium.

8. Stratigraphy (Estimated By foot traverse Measured --

9. Unit-thickness exp -- Fn-grn\% Probably $\sim 90$ Clay-mineral rich \% ed is largely slaty.

10. Lat continuity Cannot be estimated because of structural complexity. Induration and Colors Greenish gray, weathers greenish brown

11. Thickness-clay horizon Cannot be estimated because of structural complexity. Almost all of Gd exposed in lower elev. of canyon is a slate that is highly folded about generally Nlow trending subhorizontal fold axes.

12. Samples \& locations None taken (see Keystone locale).

13. Other Lithologies Dominant other 1 ithology exposed are thin (few cm) limestone interbeds. These are frequently sheared out into discontinuous stringers, particularly in structurally higher exposures. In lower exposures to the $E$ they are usually present as thick, less fissile tabular beds, 2-5 cm thick.

14. "Bedding" Sheared fissility: N35W, 50NE below 6d, th contact. N10E, $35 \mathrm{~W}$ in $6 d$ slate (internally folded); N30W 20NE, N10E, 70W on opposite limbs of $N 10 \mathrm{~W}$-trending fold in $6 \mathrm{~d}$ slate. ed slates (easternmost exp): N5W, 35E.

15. Fissl/Cleavage/Foliation All in-place "shale" exposures show well-developed slaty cleavage and locally (esp. near top) are highly phyllitic. There is no clear evidence that this foliation is or is not bedding, but lithologic changes in less-deformed "lower" section (structurally, not stratigraphically necessarily) probably represent bedding.

16. Concacts/Böundarics Base Nnt exposed.

17. Top Fairly sharp between $\theta d$ and $\theta h ;$ shale has locally flowed into limestone alld Ch baoc is brecciated. Also attitudes across contact are very discordant \& suggest some bedding plane slippage across contact.

18. Other Overlapped by Qal to SE by Hot Creek Ranch. Bounded on W by N-S striking high-angle (reverse?) fault bringing Ordovician limestones (Pogonip) \& Eureka Qzite into contact with $\in d$ and $G h$.

19. Structure. Best map reference Lowe11, J. D. (1965), "Lower \& Middle Ordavician Stratigraphy of the Hot Creek \& Monitor Ranges, Central Nevada," USGS Bulletin, V. 76, p. 259-266 
FIELD RECONNAISSANCE CHECKLIST (cont)

Locale Desigantion NN-2G

Sublocale Name East Hot Creek (EHC)

20. Regional Setting Area lies on E edge of Hot Creek Range, a crudely W-tiled \& internally faulted NNE-trending range.

21. Faults Area is bounded on E by high-angle (reverse?) fault in which limestones are brecciated and $G d$ appears to have ductilely flowed beneath intensely folded 6 .

22. Joints $G d$ here is very slaty to weakly phyllitic, \& is. frequently highly fractured at high angle to slaty cleavage.

23. Folds Abundant folds in int. shale \& limestone and local boudinage in Hales Limestone plunge $\sim 35^{\circ}$, N20W. Ed shows abundant folds \& pinch \& swell but orientation is chaotic. This evidence suggests $6 d, 6 h$ contact is a thrust fault with ENE to $E$ transport. The relationship to high-angle fault to $W(\sim 300 \mathrm{~m})$ is equivocal but crumpling appears less intense to $\mathrm{E}$ away from high-angle reverse fault \& suggests a genetic relationship: View NW

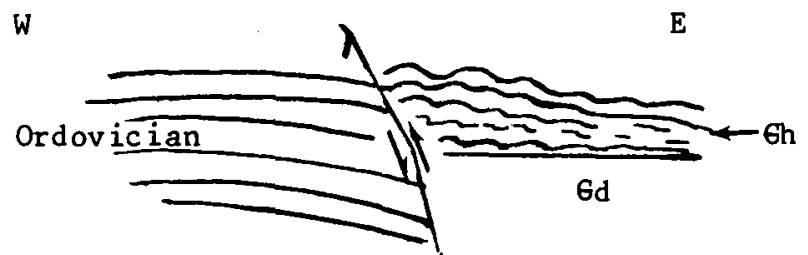

24. Topography Hot Creek is a major E-flowing stream that cuts through the axis of the Hot Creek Range. Gd outcrops lie in mountainous area flanking older alluvium/pediment surface on the $E$ margin of the Hot Creek Range.

25. Slopes, max-min Max $86 \%\left(41^{\circ}\right)$ (N side canyon); Min $2 \%\left(\sim 1^{\circ}\right)$ (Hot Creek) Et imated Avg $\sim 40 \%$

26. Ridge gradients $\sim 20 \%,-11^{\circ}$ Lengths $2000 \mathrm{~m}\left(6400^{\prime}\right)$ 'max

27. Stm gradients Only major stream is Hot Creek Channel width $250-300 \mathrm{~m}\left(800-1000^{\prime}\right)$

28. Dist.-brng to major topo break NA

29. Miscellaneous: Access rte Accessible from Tybo or US 6 following signs to Hot Creek Ranch. Drive through ranch and WNW along Hot Creek.

30. Known drill holes None

31. Known springs Hot Creek is a major perennial stream fed by numerous springs.

32. Mines (active/abandoned) Two abandoned mines lie on either side of Hot Creek along the high-angle "Mine Fault" (Lowe11, 1965)

33. Prospects/claims --

34. Mineralization/alteration None in shale away from faults. Mines along faults are adits driven into qz-cemented fault breccia with vugs containing green $\mathrm{Cu}$ carbonates.

35. Possible subsurf proj --

36. Possible testhole sites --

37. Possible geophysical sites --

38. Other =-

Geologist J. Connolly Organization UNM Date $6 / 14 / 79$ 
FIELD RECONNAISSANCE CHECKLIST

Phase II Investigations: Fine-Grained (fn/grn)

Clastic Sedimentary Rocks and Metamorphic

Derivatives in Eastern Nevada
Locale Designation NN-3A

Sublocale Name Ike Springs

1. Stratigraphic name/

designator Chainman Shale (Mc)

2. Unit above: lith/thick Ely Limestone (Pe); argillaceous limestone; $105^{\prime}$ (incomplete); contact not exposed here. Tertiary Volcanic (TV) intrude \& overlap Mc.

3. Unit below: 1 ith/thick Joanna Limestone (Mj) gray limestone; $\sim 600^{\prime}$; contact not exposed here.

4. Topo maps: $1^{\circ} \times 2^{\circ}$ Lund $15^{\prime}$ Portuguese Mt $7-1 / 2^{\prime}$ Portuguese Mt

5. Other -Sec --

6. Distr-Brng $5200 \mathrm{~m}\left(17200^{\prime}\right)$ due E Twnship =Range $=-$

7. Exp area dimensions $1.5 \mathrm{~km}^{2}\left(0.6 \mathrm{mi}^{2}\right)$ \%Bedrock exp $\sim 40$ in shale. Good exp. Shale float covers most shale outcrops. Does not include approximately equal area mapped by Quinlivan \& Rogers (1974) as Qal but probably underlain by Mc.

8. Stratigraphy (Estimated By foot traverse with Geol. Map. Measured --

9. Unit-thickness exp Perhaps $500^{\prime}$ Fn-grn\% 90 Clay-mineral rich \% Perhaps 50 . Strat. thickness is not known due to unknown but probably high degree of internal deformation.

10. Lat. continuity Appears good--shale outcrops throughout area \& other lithologies appear minimal.

Induration and Colors Gray to grayish green, weathered 1t. gray; weak, forms rounded slope.

11. Thickness-clay horizon Most Mc here appear to be shaley--how much clay is unknown.

12. Samples \& locations NN3-IS1--small N-striking ridge $2000^{\prime}$ due E of Ike's Spring.

13. Other Lithologies Shale and shaley argillite dominate sequence exposed prob $90 \%$. Only other rock types observed are laterally small (several meters or tens of meters long), thin $(<1 \mathrm{~m})$ siltite \& very fine sandstone.

14. "Bedding" N85E, $34 \mathrm{~S}$ in Mc shale, $8 \mathrm{~m}$ below thrust with Dg; N60E, 55N--shale; N90E, 40N-shale; N20E, 57NW--shale. All taken within $2000^{\prime}$ of each other.

15. Fissl/Cleavage/Foliation Shales are strongly to moderately fissile. Appears to correspond to bedding.

16. Contacts/Boundaries Base Not expused.

17. Top Unconformably overlain by various intermediate to felsic Tertiary Volcanics (TV).

18. Other $\mathrm{NW}$ boundary of area is a thrust fault with Nevada $\mathrm{Fm}(\mathrm{Dn})$ and Devil's Gate Limestone $(\mathrm{Dg}$ ) in upper plate (to NW). SE boundary is a high-angle fault with TV; down on SE side.

19. Structure. Best map reference Quinlivan, Rogers, and Dodge (1974). "Geo1. Map of the Portuguese Mountain Quadrangle," USGS Misc. Inv. Map I-804.

20. Kegional Setting Arca liss within the E foothills of the southern Pancake Range. Regionally (Quinlivin et a1, 1974) Mc lies in the lower plate of a thrust fault. 
FIELD RECONNAISSANCE CHECKLIST (cont)

Locale Desigantion NN-3A

Sublocale Name Ike Springs

21. Faults High-angle faults are not mappable in shale, but overlying volcanics are cut by numerous closely spaced (2-4 per mi) high-angle faults that generally strike $N$, and ENE.

22. Joints Shales are highly fractured, but systematic orientation not noted.

23. Folds Wide variation in measurable attitudes over short distance suggest significant internal deformation. Quinlivan (1974) shows a very generalized NE-plunging anticline in area.

24. Topography Mc outcrops form rounded knolls and ridges at base of steep slope composed of older limestone and as part of Ike Springs basin itself.

25. Slopes, $\max -\min 20 \%-13 \%\left(11^{\circ}-8^{\circ}\right)$

Estimated Avg $<10 \%$

26. Ridge gradients $\operatorname{Max} 13 \%\left(8^{\circ}\right)$ Lengths $500 \mathrm{~m}\left(1600^{\prime}\right)$

27. Stm gradients $4 \%\left(2^{\circ}\right)$ Channel width $3-10 \mathrm{~m}$

28. Dist.-brng to major topo break =-

29. Miscellaneous: Access rte $W$ on US $6 \sim 8.1 \mathrm{mi}$ past Currant, turn right on graded dirt road to radio tower. One-half mi past radio tower, turn left on unmaintained dirt road traveling along T9N-TION boundary. Road forks; take right fork, go -1.5 mi, take right fork again, which drops down into Ike Springs Wash. Proceed NW along Ike Springs Wash $\sim 2.5 \mathrm{mi}$. Mc outcrop lies both sides of wash. ( $4 \mathrm{WD}$ recommended.)

30. Known drill holes None

31. Known springs Ike Springs lies within area. Flow used for cattle. Spring location appears to be related to contact between TV and Mc.

32. Mines (active/abandoned) None

33. Prospects/claims None

34. Mineralization/alteration Minimal in shale. qz-hematite along breccia at base of thrust between $\mathrm{Mc} \& \mathrm{Dg}$

35. Possible subsurf proj $M c$ is shown underlying much of the Portuguese Mt area on map by Quinlivan et al (1974). Mapping clearly implies that much Tertiary tuff (Tscl, Tscb) between this area and other Mc area $(\sim 2 \mathrm{mi}$ to $S W)$ is underlain by Mc.

36. Possible testhole sites =-

37. Possible geophysical sites =-

38. Other =-

Geologist J. Connolly Organization UNM Date $6 / 22 / 79$ 
F IELD RECONNAISSANCE CHECKL IST

Phase II Investigations: Fine-Grained ( $\mathrm{fn} / \mathrm{grn}$ )

Clastic Sedimentary Rocks and Metamorphic

Derivatives in Eastern Nevada
Locale Designation NN-3B

Sublocale Name Portuguese

Spring

1. Stratigraphic name/

designator Chainman Shale (Mc)

2. Unit above: lith/thick Ely Limestone ( $\mathbb{P e})$; thin-bedded limestone; not observed here.

In area, Mc is unconformably overlain and intruded by tuffs, flows, and dikes of felsic to intermediate composition here designated $\mathrm{TV}$.

3. Unit below: 1 ith/thick Joanna Limestone $(M j)$; massive gray limestone, sparsely foss. often highly recrystallized \& locally silicified along fault. Up to $600^{\prime}$ thick in Port. Mt Quad to S (Quinlivan and others, 1974). No complete sections observed here.

4. Topo maps: $1^{\circ} \times 2^{\circ}$ Lund $15^{\prime}=$ 7-1/2' Sand Springs

5. Other -Sec -- Twnship =Range =-

6. Distr-Brng Area occupies SW portion of Sand Spr. 7-1/2' Quad (see attached map) From --

7. Exp area $\&$ dimensions $\sim 5.6 \mathrm{~km}^{2}\left(2.2 \mathrm{mi}^{2}\right)$. Based on mapping exp. \% estimated is in $2.2 \mathrm{mi}^{2}$ outcrop area. Another $2.0 \mathrm{mi}^{2}$ of mapped area is covered by pediment (QP) probably developed on Mc, which is not included in percentage exposure estimate.

\%Bedrock exp

8. Stratigraphy (Estimated =Measured --

9. Unit-thickness exp Minimum 1000'

Based on mapping, a partial section measured of $1000^{\prime}$ is as follows: (Photo panorama, 2 slides $W$ to $E$ ) (Top not exp.)

Highest $90 \mathrm{~m}\left(300^{\prime}\right)$ Dominantly dark gray shale with common interbedded quartzose siltstone \& very minor thin quartzite lenses ( $\mathrm{vfg}$ ).

$150 \mathrm{~m}\left(500^{\prime}\right)$ Gray shale $(\sim 1 / 3)$ interbedded with quartzose siltstone $(-1 / 2) \&$ thin (30 $\mathrm{cm}-1 \mathrm{~m})$ quartzose sandstone $(\sim 1 / G)$ lensco.

$60 \mathrm{~m}\left(200^{\prime}\right)$ Dominantly dark gray fissile shale with minor thin lenses of buff weathering $v f g$ quartzose sandstone

Lowest (Base not exp.)

As much as $600 \mathrm{~m}\left(2000^{\prime}\right)$ may be present beneath pediment and thin alluvium (QP). Fine grain \& clay\% based on this section. Shale appears to be overall more abundant than this indicates, and overall is probably closer to $75 \%$.

Fn-grn\% $\sim 65$ Clay-mineral rich \% $\sim 60$

10. Lat continuity Appears to be good Induration and Colors Shale is variable-usually soft in unweathered (?) samples. Is dark grayish green to black, weathers light gray.

11. Thickness-clay horizon Refer to Item 9. 
FIELD RECONNAISSANCE CHECKLIST (cont)

Locale Desigantion $\mathrm{NN}-3 \mathrm{~B}$

Sublocale Name Portuguese Spring

12. Samples \& locations PS1, PS2, PS3, PS4: 4 sample locales shown on map (attached). PS1 shows strong $\mathrm{H}_{2} \mathrm{~S}$ odor when broken impl. high organic content.

13. Other Lithologies Refer to Item 9.

14. "Bedding" See map. Sequence generally dips steeply E to moderately SE.

15. Fiss1/Cleavage/Foliation Shale is very thinly fissile in most locales. Occasionally is flaggy, breaking into slabs up to $1 \mathrm{~cm}$ thick.

16. Contacts/Boundaries Base Not exp. Is in contact with $\mathrm{Mj}$ but this appears to be a fault (sense of movement unknown) or at least a somewhat structurally modified strat. contact.

17. Top Strat. contact not exp. unconformably overlain by TV on E.

18. Other Locally intruded by dikes related to TV.

19. Structure. Best map reference Kleinhampl and Ziony (1967). "Prelim. Map of Northern Nye County, Nevada," USGS Open File Map. For area to south see Quinlivan and others (1974) "Geologic Map of the Portuguese Mt Quadrangle, Nye County, Nevada," USGS Misc. Inv. Map I-804.

20. Regional Setting Area lies on W margin of Pancake Range, a very crudely E-tilted range with much modification due to thrust faulting. Much of range is underlain by Quarternary \& Tertiary volcanic rocks that dominate surface exposures; are often juxtaposed with older sediments across high-angle faults.

21. Faults (See map) Major border fault on W strikes NNE \& is steeply ( 70\%) W-dipping normal fault with down-dropped block toward Big Sand Springs Valley. Two ENE-striking normal faults cut volcanics \& Mc in northern part of area and appear to roughly parallel similar faults in Portuguese Mt Quad to $S$. Changes in attitude within Mc outcrop area-suggest presence of similar faults, but actual faults are concealed by Quaternary pediment \& thin alluvium $\left(Q_{p}\right)$.

22. Joints Shales tend to be highly fractured, but no systematic orientation noted.

23. Folds Internal folds in Mc appear to be relatively minor except near mapped faults and near Martinelli spring suggesting a N-striking fault in this area.

24. Topography Generally low rounded hills and ridges in Mc outcrop area. Bounded on $N$ \& $E$ by steeper, less mature volcanic terrain \& to $W$ by the alluvial fill of Big Sand Spring Valley. To the $S$ area abuts the steep flanks of Portugese Mt.

25. Slopes, max-min $30 \%-6 \%\left(17^{\circ}-3^{\circ}\right)$

26. Ridge gradients $10 \%\left(6^{\circ}\right)$ Estimated Avg $15 \%\left(9^{\circ}\right)$

27. Stm gradients $6 \%\left(3^{\circ}\right)$ Lengths $150-1500 \mathrm{~m}\left(500-5000^{\prime}\right)$

28. Dist.-brng to major topo break See item 24 Channel width 2-5 m 
FIELD RECONNAISSANCE CHECKLIST (cont)

Locale Desigantion NN-3B

Sublocale Name Portuguese Spring

29. Miscellaneous: Access rte US 6 25-1/2 mi NE of Warm Springs, turn N on Moore's Sta Rd, go 6-1/2 mi; turn NE go 6-1/2 mi to Sand Spr. Well sign; turn E across wash past tank, bear right, then left (at fork) around low hills--go $4.7 \mathrm{mi}$; turn $\mathrm{N}$ (left) on unmaintained dirt road--go $4.7 \mathrm{mi}$ to fork and continue $\mathrm{N} \sim 8 \mathrm{mi}$ to stock tank that is in the area. High ground clearance is required on unmaintained portion and 4WD desirable. Only passable in dry weather. Trails shown crossing Big Sand Springs Valley in NE direction are not passable without cross-country travel due to washouts. Also accessible from Eureka Hwy (U.S. 50) off Nev Hwy 20.

30. Known drill holes None observed.

31. Known springs Both Martinelli Spr. and Sand Spr. supply water to cattle troughs. No flow at spr., <l gal/min at pipe to trough.

32. Mines (active/abandoned) None

33. Prospects/claims Most Mc outcrop area staked June 1978 by Bear Creek Mining Co (Kennecott)

34. Mineralization/alteration Mc is largely nonmineralized. Silicification is intense along faule on $W$ margin of arca; Mc is locally hornfelsic within $1-2 \mathrm{~m}$ of dikes shown (see map).

35. Possible subsurf proj May underlie much of volcanic terrain to E of area.

36. Possible testhole sites --

37. Possible geophysical sites --

38. Other --

Geologist J. Connolly/K. Emanuel Organization UNM Date $6 / 15-17 / 79$ 
F IELD RECONNAISSANCE CHECKLIST

Phase II Investigations: Fine-Grained ( $\mathrm{fn} / \mathrm{grn}$ )

Clastic Sedimentary Rocks and Metamorphic

Derivatives in Eastern Nevada
Locale Designation NN-3C

Sublocale Name Duckwater Hills (DH)

1. Stratigraphic name/

designator Chainman Shale (Mc)

2. Unit above: 1 ith/thick Diamond Peak Fm (Md)

3. Unit below: lith/thick Joanna Limestone (Mj). Unconformably overlapped by undifferentiated Tertiary\& Quaternary Volcanics (TQv).

4. Topo maps: $1^{\circ} \times 2^{\circ}$ Lund $15^{\prime}$ Duckwater $7-1 / 2^{\prime}$

5. Other Area lies in cntl portion of Sec 16-21\&28 Twnship 13N Range 56E

6. Distr-Brng N24E $5600 \mathrm{~m}\left(18500^{\prime}\right)$

7. Exp area \& dimensions $2.3 \mathrm{~km}^{2}\left(0.89 \mathrm{mi}^{2}\right)$ from Duckwater (Agency Hdqt:s) ever sandstone lenses preferentially exposed due to resistance.

8. Stratigraphy (Estimated By foot traverse. Tertiary \& Quaternary Volcanics (TQV). Measured --

9. Unit-thickness exp 2000'. Due to structural complexity, stratigraphic thickness is probably less. This estimate based on extrapolation of strike-dip data probably represents a "structural" thickness. (See section on structure.)

Fn-grn\% Probably 80 Clay-taineral rich \% Appears high; see sample

10. Lat. continuity Appears to be good, based on limited exposure.

Induration and Colors Dark gray, weathers light gray to yellowish brown. Generally hard, brittle.

11. Thickness-clay horizon Appears to represent most of section.

12. Samples \& locations NN3-DH1: Loc SW1/4 NW1/4 Sec 21, T13N, R56E; along arroyo; N10W, 37E

13. Other Lithologies Shale and shaley argillite appear to be strongly dominant. Other rock types include thin $(-1 \mathrm{~m} \max ) \mathrm{vfg}$ quartzose sandstones and siltstone that appear to be most common in central part of area ( $15 \%$ sandstone). Also present are dark gray thin lenses of shaley limestone.

14. "Bedding" N2OW, 50E Mc shale; N10W, 80E in $1 \mathrm{~m}$ th. gzite lens; same in adj. shale; N0, 45E Mc shale appears to be tightly folded internally. N0, 75E in fig. sandstone lens; N10W, 37E in shale: Sample NN3-DH1.

15. Fissl/Cleavage/Foliation Correspondence of fissility with orient of lenses suggesting bedding. However there is a second over printed fissility apparently related to deformation (三 folding).

16. Contacts/Boundaries Base Not exposed. All contacts with older rocks are faults.

17. Top Overlapped and intruded by TQV.

18. Other =-

19. Structure. Best map reference Kleinhampl and Ziony (1967). "Prelim. Geol. Map of Northern Nye County, Nevada," USGS Open File Map. [This map is too generalized in this area.] 
FIELD RECONNAISSANCE CHECKLIST (cont)

Locale Designation NN-3C

Sublocale Name Duckwater Hills (DH)

20. Regional Setting Area lies in the Duckwater Hills along E margin of Railroad Valley. Area primarily underlain by TV with paleozoics cropping out along western margin, and dipping generally to $W$ on $W$ side of fault between $M c$ and $M j$ and dipping mostly to $E$ within Mc.

21. Faults A major pre-volcanic thrust between $M j$ and $D g$ (Devil's Gate Limestone) dips $W$ in hills $W$ of area (photo). Mj-Mc contact is a steeply $\left(-75^{\circ}\right) \mathrm{W}$-dipping normal fault.

Evidence from this area plus Sand Springs and Ike Springe areas strongly suggest Mc occurs in the sole ( $\equiv$ lower) plate of a major regional thrust system. Where discernible, transport directions appear to have been $\mathrm{E}$ to $\mathrm{NE}$.

22. Joints Shales are highly fractured at high to mod. angle to fissility but quantitative est imate not made.

23. Folds Variations in strata and dip of fissility on outcrop scale suggest tight internal folds. This is supported by brecciation \& folding in $\mathrm{Dg} \& \mathrm{Mj}$.

24. Topography Mc outcrops in very low ridges within smal1 ( 1-1/2 mi wide) intermontane valley.

25. Slopes, max-min Essentially same as streams. Estimated Avg --

26. Ridge gradients =Lengths =-

27. Stm gradients $4 \%\left(2^{\circ}\right)$ Channel width $1-3 \mathrm{~m}$

28. Dist.-brng to major topo break Area occurs along $W$ margin of Duckwater Hills and is separated from Duckwater Valley by fault-bounded ridge of $\mathrm{Mj}$ and $\mathrm{Dg}$.

29. Miscellaneous: Access rte Proceed NNW from Currant on NV Hwy 20. Pavement ends in 18.7 mi. $2.0 \mathrm{mi}$ after end pavement, turn NE on gravel road. Go through gap (1.0 mi). Road opens into NNW-trending valley of low hills underlain by Mc.

30. Known drill holes None observed.

31. Known springs None. Several springs lie in Duckwater Valley to $W$.

32. Mines (active/abandoned) None

33. Prospects/claims One prospect pit seen; no claim stakes.

34. Mineralization/alteration Only alt. observed in shale is local oxidation \& yellowish-brown stain. Faults in carbonate units ( $\mathrm{Dg}-\mathrm{Mj}$ ) are highly oxidized \& silicified with some argillic alt.

35. Possible subsurf proj May underlie volcanics to east.

36. Possible testhole sites =-

37. Possible geophysical sites --

38. Other --

Geologist J. Connol1y Organization UNM Date $6 / 23 / 79$ 
F IELD RECONNAISSANCE CHECKL IST

Phase II Investigations: Fine-Grained (fn/grn)

$\mathrm{Cl}$ astic Sedimentary Rocks and Metamorphic

Derivatives in Eastern Nevada
Locale Designation $\mathrm{NN}-3 \mathrm{D}$

Sublocale Name Big Louie

West

1. Stratigraphic name/ designator Chainman Shale (Mc)

2. Unit above: 1 ith/thick Ely Limestone ( $\mathbb{P e}$ ) ?? No units of this description mapped in this part of range. In this area Tertiary (and Quaternary?) volcanics (TV \& QTb) unconformably overlie paleozoic sediments as old as Mississippian (Chainman Shale is youngest PZ unit).

3. Unit below: $1 \mathrm{ith} /$ thick Joanna Limestone (Mj) thick-med bedded gray crinoidal limestone.

4. Topo maps: $1^{\circ} \times 2^{\circ}$ E1y $15^{\prime}$ Moody Peak Quad 7-1/2' =-

5. Other -$\operatorname{Sec}=-$ Twnship =Range --

6. Distr-Brng $600 \mathrm{~m}\left(1800^{\prime}\right)$ due $\mathrm{E}$ from Moody Peak (Elev 8883')

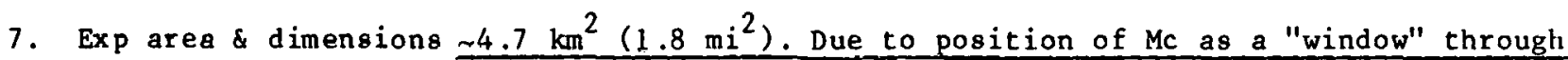
Tertiary \& Quaternary volcanics, much MC is covered by volcanic float, particularly on $W$. Best exposures (some continuous over stratigraphic intervals up to 200') are in deep channels on $\mathrm{E}$ side of exposed area. \%Bedrock exp Avg 10

8. Stratigraphy (Estimated From foot trav. \& geol. sketch map Measured =-

9. Unit-thickness exp Min $500^{\prime}$, poss. Max 3500'. One pace-compass measured section (partial) is $2100^{\prime}$ thick \& consists of $95 \%$ gray clay shale \& $-5 \%$ reddish-brown weathering shaley siltstone. Minimum is based on areas of good exposures, mostly E side of area. Max based on topographic assumption of area underlain by shale \& "representative" dips taken away from edges (tectonic). Average dip $30^{\circ} \mathrm{SE}$.

Fn-grn\% 90 Clay-mineral rich \% 80

10. Lat continuity Exposures are not continuous but appear to be good. Tnduration and Colors Generally soft \& fissile; gray to dark gray; weathered to greenish to brownish clay rich soil.

11. Thickness-clay horizon Minimum $100^{\prime}$ (95\% clay shale); probably much more.

12. Samples \& locations BLW-1: N34E, 30SE, brownish gray shale ( $\theta$ on map).

13. Other Lithologies Dominant other rock type exposed in area is vfg quartzose sandstone $\&$ siltstone in very thin interbeds (few $\mathrm{cm}$ to tens of $\mathrm{cm}$ ). Minor calcareous shale locally present. Siltstone, sandstone, calcareous shale probably no more than $10 \%$.

14. "Bedding" N3/E, 30SE Mc shale (sample); N10E, 10SE: Mc shale $10 \mathrm{~m} \mathrm{SW}$ of previous; N70W, 70NE Mc shale fault with Ddg; N10W Mc shale, 20NW (near mouth of canyon); N24E, 17NW Mc shale N74E, $25 \mathrm{~S} \mathrm{MC}$ shale $100 \mathrm{~m} \mathrm{NE}$ of previous.

15. Fissl/Cleavage/Foliation Shale highly fissile most areas, locally slabby to flaggy. Fisillity generally parallel to nonshale interbeds, probably $\equiv$ bcdding.

16. Contacts/Boundaries Base Strat. base not exposed.

17. Top Unconformably overlain by TV. 
F IELD RECONNA ISSANCE CHECKLIST (cont)

Locale Designation $\mathrm{NN}-3 \mathrm{D}$

Sublocale Name Big Louie West

18. Other Numerous klippes of Devil's Gate Limestone (Dg) overlie Mc in outcrop area; QTb is in fault contact on E margin (see structure Items $19 \& 21$ ).

19. Structure. Best map reference Kleinhampl \& Ziony (1967). "Preliminary Geologic Map of Northern Nye County, Nevada," USGS Open File Map (very good here).

20. Regional Setting Area 1 ies in $N$ Central Pancake Range in an area underlain chiefly by Tertiary \& Quaternary volcanic rocks that are often in high-angle fault contact with Paleozoic sediments. In most cases, Paleozoic rocks are in thrust fault contact with each other as well as affected by high angle faults. High angle faults show a general NNE trend parallel with range margin and elongation; several NNE trending faults cut $Q a 1 \sim 8 \mathrm{mi}$ due $W$ of locality. Subsidiary $N$ to NNW trending normal faults are present locally. Paleozoic rocks are exposed only in erosional (?) windows through volcanic cover.

21. Faults High-angle fault, strikes $N$, down on E juxtaposes Paleozoics \& QTb on E margin. Several klippe (photo) of Ddg overlie Mc in outcrop area. Lower plate rocks are Mc, upper plate sequences include $\mathrm{Mj}$, DP (pilot shale) and Ddg often in stratigraphic sequence. Ddg base of klippe (near sample loc) is marked by a breccia zone in limestone \& local oxidized zones. Some bedding plane fractures may be present.

22. Joints None noted in shales; overlying klippe (Ddg) show some calcite-filled fractures \& minor reddish alt. prob related to faulting.

23. Folds Var. in strike \& dip suggest internal deformation but these are not systematic \& may be assoc. with marginal faults. Ddg shows broad NNW or SSE trending broad folds in klippe suggestive of ENE transport of thrust sheets.

24. Topography Area is in intermontane park area (avg elev.6900') with rugged mountainous terrain on $W$ (Moody $M t$ ) and low scattered mountains to $E$.

25. Slopes, max-min (In MC (avg) to E, $7 \%\left(4^{\circ}\right)$; in surrounding TV, $66 \%-33 \%\left(34^{\circ}-18^{\circ}\right)$ ). Estimated Avg =-

26. Ridge gradients =Lengths =-

27. Stm gradients Drains basin $4 \%\left(2.5^{\circ}\right)$ to E Channel width 3-15 m (10-50')

28. Dist.-brng to major topo break E edge is $2700 \mathrm{~m}\left(9000^{\prime}\right)$ to W of Duckwater Valley margin.

29. Miscellaneous: Access rte From int. NV 20 W US 50 ( 10 mi E of Eureka), proceed S toward Duckwater (pavement ends at $11.3 \mathrm{mi}$; Pogues station $15.7 \mathrm{mi}$ ) $25.1 \mathrm{mi}$; turn sW onto good dirt road \& continue $5.3 \mathrm{mi}$ to Big Louie Spring ( 2 willow trees). At Spring take NW fork \& follow road $2.8 \mathrm{mi}$ up wash. At this point, intermontaine basin opens to west. Mc exposures in basin, best exp. on $E$ side along washes.

30. Known drill holes None noted.

31. Known springs $\mathrm{CaCO}_{3}$ rich water flows from beneath largest Ddg klippe and flows on Mc to mouth of basin where it sinks into alluvium.

32. Mines (active/abandoned) None 
FIELD RECONNAISSANCE CHECKLIST (cont)

Locale Designation $\mathrm{NN}-3 \mathrm{D}$

Sublocale Name Big Louie West

33. Prospects/claims None noted

34. Mineralization/al teration None noted

35. Possible subsurf proj Probably underlies much of volcanics to $W$.

36. Possible testhole sites --

37. Possible geophysical sites =-

38. Other Area clear cut logged -70 yr ago. Ruins rel to logging.

Geologist J. Connol1y Organization UNM Date $7 / 17 / 79$ 
FIELD RECONNA ISSANCE CHECKL IST

Phase II Iuvestigations: Fine-Grained ( $f n / g r n$ )

Locale Designation NN-3E

Clastic Sedimentary Rocks and Metamorphic

Derivatives in Eastern Nevada

Sublocale Name Duckwater

Peak

1. Stratigraphic name/

designator Chainman Shale (Mc)

2. Unit above: 1ith/thick Diamond Peak Fm (Md) sandstone, conglomerate, siltstone Mc is overlain on $W$ by Tertiary ash flow tuffs \& basalts \& other flows (designated TV).

3. Unit below: 1ith/thick Joanna Limestone (Mj)

4. Topo maps: $1^{\circ} \times 2^{\circ}$ Lund $15^{\prime}$ Moody Peak

5. Other =- $\operatorname{Sec}=$ $7-1 / 2^{\prime}=$

6. Distr-Brng $2100 \mathrm{~m}\left(6800^{\prime}\right) \mathrm{N} 26 \mathrm{E}$ Twnship =Range --

7. Exp area \& dimensions -from Duckwater Peak recognizable by float. Excellent exposures.

8. Stratigraphy (Estimated By foot traverse of area. $\%$ Bedrock exp $\sim 50$; rest easily

9. Unit-thickness exp $\simeq 200 \mathrm{~m}\left(600^{\prime}\right)$. Stratig. variation suggest quartzite, arkosic quartzite \& conglomerate increase in abundance \& thickness upward. Hose \& Blake (1976) suggest $1000^{\prime}$ of shale in Pancake Range \& thus several hundred feet of Mc may underlie valley in central part of anticline. Prominent hexagonal desiccation cracks in valley floor are indicative of a high proportion of expandable clays in soil developed on Mc.

Fn-grn\% 60 Clay-mineral rich \% $\sim 40$

10. Lat continuity Difficult to estimate, but may be good in lower part of section. Induration and Colors Dark greenish gray, weathers gray. Brittle to soft clay shale.

11. Thickness-clay horizon Difficult to estimate. Need subsurface data.

12. Samples \& locations NN3-DP1: in axis of NNW-trending valley, 6800', N25E of Duckwater Peak (lowest exp. in sect.)

13. Other Lithologies Within shale are locally dev fetid limestone concretions containing siderite. Other interbeds are thin $(<1 \mathrm{~m})$ med to very fine arkosic (t) quartzite as apparent lenses - size ranges into silt. Near top of exposed sect. lenses appear more continuous $\&$ abundant $\&$ are up to several meters thick.

14. "Bedding" Shale fissility: N10W, 9W (NW3-DP1); N5W, 32W to W of Prev in shale; N55E, 10SWarkosic quartzite on ridge; N25E; 8W-gzite W flank anticline; NO, 18W in silt-shale W flank anticline.

15. Fisol/Cleavage/Fnliation Shales are very fissile; concordence of lenses \& orientation of fissilty suggest fissility $\equiv$ bedding.

16. Contacts/Boundaries Base Base not exposed in this area.

17. Top Grades upward through increasing sandstone abundance to base of Diamond Peak Fm (arbitrarily lowest cliff-forming conglomerate), which also includes interbedded silt \& shale.

18. Other Is overlapped by Tertiary volcanic (TV) to $S$ and $W$. 
FIELD RECONNAISSANCE CHECKLIST (cont)

Locale Designation $\mathrm{NN}-3 \mathrm{E}$

Sublocale Name Duckwater Peak

19. Structure. Best map reference Kleinhampl \& Ziony (1967). "Preliminary Geologic Map of Northern Nye County, Nevada," USGS Open File Map; for part in White Pine County see Hose, R. K. and Blake, M. C. Jr. (1976), "Geology and Mineral Resources of White Pine County, Nevada, Part 1-Geology", Nev Bur Mines \& Geology Bulletin 85.

20. Regional Setting Area lies in portion of Pancake Range characterized by abundant volcanic rocks, which overlap Mc on $S$ and $W$. Area is broadly a N-trending, gently N-plunging anticline, but this may be due to thrust faulting not recognized by Kleinhampl \& 2 iony (1967) but shown by Hose \& Blake (1976).

21. Faults None observed, but Md \& Mc may be in fault contact (thrust ?) on E edge of area. More detailed mapping required.

22. Joints None observed. Shales tend to be highly fractured.

23. Folds Area is a gently NNE-plunging asymetric anticline with E limb dipping $\sim 40^{\circ}$, $W 1$ imb dipping $\sim 10^{\circ}-15^{\circ}$. Small-scale folds are not readily apparent.

24. Topography Area is one of low-to-moderate NNE-trending strike ridges in Mc. Area lies astride drainage divide of Pancake Range near Red Rock Summit.

25. Slopes, $\max -\min 38 \%-11 \%\left(21^{\circ}-7^{\circ}\right)$

26. Ridge gradients $9 \%\left(5^{\circ}\right)$ Estimated Avg 15\%

27. Stm gradients $4 \%\left(2^{\circ}\right)$ Lengths Up to $3200 \mathrm{~m}(2 \mathrm{mi})$

28. Dist.-brng to major topo break 3-4 mi on WNW-ESE axis from Little Smoky Valley (NW) \& Duckwater Valley (SE).

29. Miscellaneous: Access rte From Currant, go NNW on NV Hwy 20. Pavement ends at $\sim 18.7 \mathrm{mi}$. Continue $16.5 \mathrm{mi}$ after pavement ends; turn left (SW) onto unmaintained dirt road that becomes jeep trail in $-1 / 2 \mathrm{mi}$. This trail encircles entire area ( \& is not completely shown on Moody Peak 15' Quad) \& requires 4WD.

30. Known drill holes None observed.

31. Known springs None in area. Nevada Governors Spring lies just outside area to NE.

32. Mines (active/abandoned) None

33. Prospects/claims None

34. Mineralization/alteration Minimal in Mc. Siderite present in limestone concretions \& some minor green stain in conglomerate of $\mathrm{Md}$.

35. Possible subsurf proj May project under volcanics on W limb of anticline. Probably underlies central NNE trending valley along core of anticline.

36. Possible testhole sites Good location would be just along $W$ flank of anticline in Mc.

37. Possible geophysical sites =-

38. Other -- 
1. Stratigraphic name/

designator Chainman Shale (Mc)

2. Unit above: 1 ith/thick Diamond Peak Fm (Md) medium to coarse gz sandstones with locally thick chert pebble cgl \& finer grained interbeds.

3. Unit below: $1 \mathrm{ith} / \mathrm{thick}$ Joanna Limestone $(M j)$ not exposed here

4. Topo maps: $1^{\circ} \times 2^{\circ}$ Ely $15^{\prime}$ Moody Peak $7-1 / 2^{\prime}=$

5. Other $=\operatorname{Sec}$ Wl/21,2,3,10,11,14,15 Twnship $15 \mathrm{~N}$

6. Distr-Brng =- $\cdots$ from -

7. Exp area \& dimensions $\sim 3 \mathrm{mi}(\mathrm{N}-\mathrm{S}) \times 2 \mathrm{mi}(\mathrm{EW}) ; \sim 7.5 \mathrm{~km}^{2}\left(2.9 \mathrm{mi}^{2}\right)$. Stratigraphic interval exposed is very close to Md-Mc contact and $10 \%$ of area is underlain by coarse sandstones \& conglomerates typical of Md.

\% Bedrock exp 20 coarser clastic \& limey float dominant.

8. Stratigraphy (Estimated By auto \& foot traverse. . . Measured :-

9. Unit-thickness exp $\sim 550 \mathrm{~m}\left(1800^{\prime}\right)$. Area slopes westward at $1^{\circ}-2^{\circ}$ while beds dip $20^{\circ}$ to ENE. Projecting thickness yields $-550 \mathrm{~m}\left(1800^{\prime}\right)$ of section exposed. However there appears to be only the uppermost Mc-Md. Shale may be more dominant in subsurface. Fn-grn\% 60 Clay-mineral rich \% -50

10. Lat continuity Fairly good, incl several persistent limestone beds \& quite-conglomerate horizons are present \& form $\mathrm{N}$ - to NNW-striking ridges.

Induration and Colors Shale is soft, dark gray to black.

11. Thickness-clay horizon Can't be sure due to exposures, but prob at 1 east $30 \mathrm{~m}$ (100').

12. Samples \& locations Sample PS-1 (loc on map). Just $W$ of low ridge held up by fg limestone bed. N35W, 28SW.

13. Other Lithologies Conglomerate horizon a few meters thick (assigned to Md) forms most prominent ridge. Also incl some thin (few $\mathrm{cm}$ to tens of $\mathrm{cm}$ ) silty limestone beds; qzites \& siltstones are also present.

14. "Bedding" N10W, 21W, Md qzite \& conglomerate in strike ridge; N55E, 32NW of previous; shale just NE; N25E, 85E shale E of previous; N60E, $6 \mathrm{NW}$ in shale; N30W, 16 SW in shale; N20W, $21 \mathrm{~W} \mathrm{fg}$ limestone bed.

15. Fissl/Cleavage/Foliation Shales are very fissile \& locally slabby.

16. Contacts/Boundaries Base Not exposed.

17. Top Mc-Md contact gradational by increasing abundance of coarser clastics.

18. Other Overlapped by alluvium of Little Smoky Valley to $W$.

19. Structure. Best map reference Hose, R. K. and Blake, M. C. (1976). "Geology and Mineral Resources of White Pine County, Nevada," Nev Bur Mines \& Geol. Bulletin 85 (scale $1: 250,000)$. 
FIELD RECONNAISSANCE CHECKLIST (cont)

Locale Designation $\mathrm{NN}-3 \mathrm{~F}$

Sublocale Name Pogues Station

20. Regional Setting Lies in area of Pancake Range characterized by westward tilting of all sediments through "Older Tertiary." In this area blockfaulting-tilting has apparently been dominant over thrusting. There are no volcanics in local area.

21. Faults None clearly exposed. Two N-trending faults that partly repeat the section are mapped by Hose \& Blake in S part of area.

22. Joints None observed. Conglomerate pebbles in Md are notably not fractured here as in the Duckwater Peak locale.

23. Folds Variation in attitude of shale suggests some internal deformation, but dip of competent interbeds is consistently gently to $W$; this suggests internal deformat ion is probably related to local surficial adjustments rather than regional deformation. The deformation could be related to bedding--parallel slip in shale between more competent beds.

24. Topography Area is one of generally low relief N-trending strike ridges between the gently mountainous Pancake Range on $E$ and pediment-alluvium of Little Smoky Valley on $W$.

25. Slopes, max-min In Mc-Md area (mostly to $\mathrm{W}), 4 \%-3 \%\left(2.3^{\circ}-1.6^{\circ}\right.$ ) Estimated Avg NA

26. Ridge gradients Max perpendicular to ridge: $20 \%\left(11^{\circ}\right)$ Lengths $\max 3000 \mathrm{~m}\left(10^{\left.000^{\prime}\right)}\right.$, $\mathrm{N}-\mathrm{S}$.

27. Stm gradients No major stms.; same as min. slopes Channel width $3 \mathrm{~m}\left(10^{\prime}\right)$

28. Dist.-brng to major topo break Lies on major topo break (see Item 24).

29. Miscellaneous: Access rte From intersection of US 50 \& NV 20 (10 mi E of Eureka) proceed $15.9 \mathrm{mi}$ SE to stock tanks \& ruined cabin at Pogues Sta. Mc-Md outcrops to NW \& SW.

30. Known drill holes None

31. Known springs Spring at Pogues Sta flows 1 pint/min to stock tanks. Spring locale appears to be related to Md-Mc contact with permeable clastics over impermeable shale.

32. Mines (active/abandoned) None

33. Prospects/claims None

34. Mineralization/alteration None observed.

35. Possible subsurf proj Mc probably underlies much of alluvium to W. Regional evidence (Duckwater Pk \& Big Louie West areas, NN-3) suggests that much of this part of Pancake Range is underlain by Mc either beneath Md, beneath Tertiary volcanics, or as the lower plate of a thrust fault.

36. Possible testhole sites --

37. Possible geophysical sites =-

38. Other This area cont inuous with Duckwater Peak-Red Rock Summit (NN-3E) \& so considered here in reconnaissance.

Geclogist J. Connolly Organization UNM Date $7 / 20 / 79$ 
FIELD RECONNAISSANCE CHECKLIST

Phase II Investigations: Fine-Grained (fn/grn)

Clastic Sedimentary Rocks and Metamorphic

Derivatives in Eastern Nevada
Locale Designation NN-4A

Sublocale Name Currant

Summit SE

1. Stratigraphic name/

designator Chainman Shale (Mc)

2. Unit above: 1 ith/thick Ely Limestone ( $\mathbb{P e})$

3. Unit below: Iith/thick Joanna Limestone $(\mathrm{Mj})$

4. Topo maps: $1^{\circ} \times 2^{\circ}$ Lund. Location approx. due to lack of more detailed maps. $15^{\prime}=$

5. Other Same as item 4. Sec Parts of Sec. 27,28,33,34_Twnship 11N Range 6qE

6. Distr-Brng Same as item 4 .

7. Exp area \& dimensions $3.6 \mathrm{~km}^{2}\left(1.4 \mathrm{mi}^{2}\right)$ from -area covered by 1 imestone float on $S \&$ volcanic float on $\mathrm{N}$. Area $\sim 2.5 \mathrm{~km} \times 1.5 \mathrm{~km}(1.6 \mathrm{mi}$ x $0.9 \mathrm{mi}$ ).

8. Stratigraphy (Estimated By foot traverse Measured =-

9. Unit-thickness exp $60 \mathrm{~m}\left(200^{\prime}\right)$.

Fn-grn\% Unknown $\mathrm{fg} \%$, but appears to dominate exposures in low valley. Clay-mineral rich \% Very thin fissile dark gray organic rich shale appears strongly dominant.

10. Lat. continuity Unknown but may be good.

Induration and Colors Generally soft, weak. Dark gray to black, weathered gray to dark gray

11. Thickness-clay horizon Unknown; $60 \mathrm{~m}\left(200^{\prime}\right)$. May be present in exposure.

12. Samples \& locations None taken.

13. Other Lithologies Could not be determined because of poor exposures but absence of resistant knobs seen in other areas suggests shale is strongly dominant.

14. "Bedding" None taken in shale because of poor exposures. Mj (?) dips generally to $S$ or SW gently $\left(10^{\circ}-20^{\circ}\right)$.

15. Fissl/Cleavage/Foliation Shale is thin $(\sim 1 / 2 \mathrm{~mm})$ fissile \& platy.

16. Contacts/Boundaries Base Both fault \& depositional contact with $\mathrm{Mj}$.

17. Top Mc-Pe contact not exp. Is unconf. overlain by TV on $N$.

18. Other Map relations shown by Kleinhampl \& Ziony (1967) are confusing \& suggest much structure has been omitted from map.

19. Structure. Best map reference Kleinhampl \& Ziony (1967). "Preliminary Geologic Map of Northern Nye County, Nevada," USGS Open File Map.

20. Regional Setting Area is within part of Horse Range characterized by high-angle faults showing general $\mathrm{N}$ strike. Observed dips in $\mathrm{Mj}$ are generally low \& area may be a generally N-plunging syncline. Topographic inversion of stratigraphy (i.e., Mj above strat. higher Mc) suggests some thrust faulting may be involved in area omitted by Kleinhampl \& $Z$ iony. This can only be resolved by more detailed mapping on larger scale base maps. 
FIELD RECONNAISSANCE CHECKLIST (cont)

Locale Designation NN-4A

Sublocale Name Currant Summit SE

21. Faults None clearly observed except $M_{j}-M_{c}$ with $N$ strike. See discussion above.

22. Joints None observed. Mj shows local intense brecciation.

23. Folds Brecciation of $M j$ suggests Mc may be internally folded. More detailed mapping required.

24. Topography Exposures occur in low valley $\sim 3 / 4 \mathrm{mi}$ wide $\times 1.5 \mathrm{mi}$ long surrounded by a subdued mount ainous topography.

25. Slopes, max-min In Mc valley (avg), $8 \%\left(4.5^{\circ}\right)$; in Mj to s (avg), $16 \%\left(9^{\circ}\right)$. Slope in TV to N: all slopes are very approximate due to lack of detailed, large scale topographic maps. Estimated Avg =-

26. Ridge gradients =Lengths =-

27. Stm gradients Intermittent in va1ley: $4 \%\left(2.5^{\circ}\right)$ to $\mathrm{SE}$ Channel width $3-6 \mathrm{~m}\left(10-20^{\prime}\right)$

28. Dist. -brng to major topo break $-2 \mathrm{mi}$ S45E to Pediment sloping SE to White River Valley.

29. Miscellaneous: Access rte From Currant, proceed $28.3 \mathrm{mi}$ E on US 6 (2.5 mi past USFS Currant Creek turnoff \& Currant Creek Bridge) to maintained (not very wel1) dirt road leading first ESE then $S$ parallel to broad valley, $\sim 2.5 \mathrm{mi}$. Take road to E $\sim 2 \mathrm{mi} E$ across low pass into E-W-striking valley. Mc outcrops in valley.

30. Known drill holes None

31. Known springs None noted in area. Lush vegetation to E may be rel to groundwater.

32. Mines (active/abandoned) None

33. Prospects/claims Large outcrop areas of shale \& volcanics staked by Earth Resources Corp (Golden Colo.) May 1979 .

34. Mineralization/alteration Silicification \& red staining along Mj-Mc fault is common.

35. Possible subsurf proj Considerable thickness of Mc may underlie valley \& Mj outcrop area to south,

36. Possible testhole sites May be good locale to test Mc subsurface thickness \& obtain fresh samples of shale.

37. Possible geophysical sites None

38. Other =-

Geologist J. Connolly Organization UNM Date $5 / 21 / 79$ 
FIELD RECONNAISSANCE CHECKLIST

Phase II Invcstigations: Fine-Grained ( $\mathrm{fn} / \mathrm{grn}$ )

Locale Designation $\mathrm{NN}-4 \mathrm{~B}$

Clastic Sedimentary Rocks and Metamorphic

Derivatives in Eastern Nevada

Sublocale Name SW Horse

Range

1. Stratigraphic name/

designator Pogonip Group (Op)

2. Unit above: 1 ith/thick Eureka Quartzite (Oe); orthoquartzite

3. Unit below: 1ith/thick Windfall Fm ( $6 \mathrm{w})$; limestone \& cherty limestone.

4. Topo maps: $1^{\circ} \times 2^{\circ}$ Lund

$15^{\prime}$ Currant

7-1/2' Currant

5. Other -Sec -Twnship =-

from "Stone Cabin"

6. Distr-Brng $4000 \mathrm{~m} \mathrm{S60E}$

7. Exp area \& dimensions $\sim 1 \mathrm{~km}^{2}\left(0.4 \mathrm{mi}^{2}\right)$ \%edrock exp $\sim 30$. Exposures poorer to $\mathrm{W}$ beneath pediment. Dimensions of $0 p$ outcrop as shown by $\mathrm{k} 1$ einhampl \& Ziony $(1967) \sim 4 \mathrm{~km} \mathrm{~N}-\mathrm{S} \times 0.4 \mathrm{~km}$ $\mathrm{E}-\mathrm{W}(2.5 \mathrm{mi} \times 0.25 \mathrm{mi})$.

8. Stratigraphy (Estimated By font traverse $w / m a p$. Measured --

9. Unit-thickness exp $500 \mathrm{~m}\left(1500^{\prime}\right)$ Fn-grn\% 0 observed Clay-mineral rich $\%$ NA

10. Lat continuity $\mathrm{NA}$ Induration and Colors NA

11. Thickness-clay horizon None observed

12. Samples \& locations None

13. Other Lithologies Dominant lithology is gray, thickly bedded to massive, very sparsely fossiliferous predominantly clastic limestone with common nodular chert, often composing up to $30 \%$ in some horizons. Rare vfg limey siltstone is only other common rock type. Only uppermost $O p$ is exposed; rest beneath pediment and older alluvium.

14. "Bedding" N1OE, 78E in Op with chert concretions; N1OW, 80E in Oe. capping OP; N15E, 82E in gray limestone, $0 p$ :

15. Fissl/Cleavage/Foliation NA

16. Contacts/Boundaries Base Not exposed.

17. Top Overlain by Oe without any angular discordance.

18. Other Section is cut off by poorly exposed fault juxtaposing Qoa (older alluvium) with Op on $\mathrm{W}$.

19. Structure. Best map reference Kleinhampl \& Ziony (1967). "Preliminary Geologic Map of Northern Nye County, Nevada," USGS Open File Map

20. Regional Setting Area lies on $W$ flank of $S$ Horse Range near the lowest exposures of a steeply $F-t i l t e d$ homoclinal sequence which includes strata ranging in age from ordovician to Mississippian. Range and rocks exposed in homocline strike $\sim N$.

21. Faults Area is bordered on $W$ by $-N-S$ high-angle fault juxtaposing $0 p \&$ Q $Q$ a. An extensive pediment is dev. on Qoa.

22. Joints --

23. Folds None observed. Strike-dip pattern is very consistent in area.

24. Topography =-

25. Slopes, max-min NA -- no shale Estimated Avg NA 
F IELD RECONNAISSANCE CHECKLIST (cont)

Locale Designation NN-4B

Sublocale Name SW Horse Range

26. Ridge gradients NA

Lengths NA

27. Stm gradients NA

Channel width NA

28. Dist.-brng to major topo break =-

29. Miscellaneous: Access rte Proceed SE $-3.7 \mathrm{mi}$ on graded dirt road from Currant. (Stone

Cabin on right at $-3: 3 \mathrm{mi}$ ) Turn E on unmaintained trail $\sim 0.9 \mathrm{mi}$. Stop at prominent Eureka

Quartzite Ridge. Op outcrops lie to W of Eureka Quartzite Ridge. This trail is only

passable by $4 \mathrm{WD}$.

30. Known drill holes None observed.

31. Known springs None observed.

32. Mines (activè/abandoned) None observed.

33. Prospects/claims Few claim stakes dated 1975 noted in area near Op outcrop,

34. Mineralization/alteration None observed.

35. Possible subsurf proj --

36. Possible testhole sites --

37. Possible geophysical sites --

38. Other --

Geologist J. Connolly Organization UNM

Date $6 / 24 / 79$ 
FIELD RECONNAISSANCE CHECKLIST

Phase II Investigations: Fine-Grained (fn/grn)

Clastic Sedimentary Rocks and Metamorphic

Derivatives in Eastern Nevada
Locale Designation NN-5A

Sublocale Name Fox Mt North (FMN)

1. Stratigraphic name/

designator Chainman Shale (Mc)

2. Unit above: 1 ith/thick Ely Limestone $(\mathbb{P e}) ;$ gray limestone, massive to med bedded.

3. Unit below: 1ith/thick Joanna Limestone (Mj) gray limestone; not exp here

4. Topo maps: $1^{\circ} \times 2^{\circ}$ Lund $15^{\prime}=$ 7-1/2' Timber Mt Pass NE

5. Other $=-\operatorname{Sec} \mathrm{E} 1 / 2 \mathrm{Sec} 12 \& \mathrm{NW} 1 / 4 \mathrm{Sec} 18, \mathrm{SW} 1 / 4 \mathrm{Sec} 7$. Twnship T4N Range R61E 62E (unsurveyed)

6. Distr-Brng 2800' N39W from NE corner (surveyed) Sec 13, T4N, R61E

7. Exp area \& dimensions $21.5 \mathrm{~km}^{2}\left(0.6 \mathrm{mi}^{2}\right)$. Max area dimension $\sim 2 \mathrm{~km}(\mathrm{WNW}) \times 0.8 \mathrm{~km}(\mathrm{NNE})$ $(1.3 \mathrm{mi} \times 0.5 \mathrm{mi})$.

\%Bedrock exp Less than 5; Most float covered, bedrock deeply weathcred.

8. Stratigraphy (Estimated By foot traverse w/map. Measured --

9. Unit-thickness exp $\simeq 250^{\prime}$ Fn-grn\%? clay-mineral rich \% ?

10. Lat continuity Unknown because of poor exposure.

Induration and Colors Only weathered shale exp.--weathered to pale brownish soil. No "shale" exposed. High clay content in brown soil indicated by strong shrinkage cracks \& "hollow" feel to ground. Implies clay-rich parent.

11. Thickness-clay horizon Unknown because of poor exposure.

12. Samples \& locations None.

13. Other Lithologies Only lithology exp as bedrock is vfg well-sorted quartzite showing some red color due to hematite stain. (Poor exp probably due to absence of active stream erosion to cut down to bedrock. This is case in all areas but Gap Mt $1 \mathrm{~S}$.)

14. "Bedding" Adj to fault (?) SW down (?) N72W, 42S Pe or Mj??; N60W, 25NE--dom. attitude in Pe; N80E, 20N in qzite in Mc, N70E, 22N qzite in Me.

15. Fiss1/Cleavage/Foliation Unknown; not exposed.

16. Contacts/Boundaries Base Not exposed.

17. Top Not exposed.

18. Other Fault contact (strike WNW) with Simonson Dolomite (DSi) on S that underlies Fox Mt. Fault centered with Quat-Tert basaltic (QTb) on N. Also locally intruded by Latite dikes of WNW trend. Mc exposures and QTb exposures are poor in area, DSi very good since strong cliff forms.

19. Structure. Best map reference Kleinhampl \& Ziony (1967). "Preliminary Geologic Map of Northern Nye County, Nevada," USGS Open File Map; also see Kellogg (1964). "Cenozoic Stratigraphy \& Structure of the Southern Egan Range, Nevada, "Geol Soc Am Bullet in, 75, No. 4 \& Kellogg, (1963). "Paleozoic Stratigraphy. of the Southern Egan Range, Nevada, Geol Soc Am Bulletin 74 , pp 685-708. 
FIELD RECONNAISSANCE CHECKLIST (cont)

Locale Designation NN-5A

Sublocale Name Fox Mt North (FMN)

20. Regional Setting Gap Mt \& Fox Mt areas are a topographic extension of the Southern Egan Range; however, tilted beds are generally to $W$ or NNW and high-angle faults of NW- \& NNE-trend dominate the area. Thrust faults have not been mapped in area \& largly homoclinal (though faulted) sequences appear to dominate. Exposures are poor in most areas. Tertiary $\&$ Quaternary volcanics form $-50 \%$ of exposed bedrock \& are usually shown (by kleinhampl \& Ziony) in fault contact with Paleozoic strata.

21. Faults The S border fault with DSi trends N70W \& is well exposed as zone of oxid-silic in colomite. Fault with QTb is poorly exposed \& 1argely inferred. Field obs sugg that contact may be in part depositional.

22. Joints Sandstones are largely highly fractured in surf exposures but show no obvious uniform orientation aside from high angle to bedding.

23. Folds No internal folds observed because of poor exposures of Mc. Thin sliver of Pe appears tray-folded adjacent to fault in Mc.

24. Topography Area is one of gentle slightly hilly topography in Mc. Most hills are underlain by quartzite lenses that form gentle strike ridges. Rugged mountainous topography characterized Fox Mt to $S$ \& low hills \& isolated steep peaks characterize QTb to $N$.

25. Slopes, max-min In Mc generally to E, $5 \%-3 \%\left(3^{\circ}-1.7^{\circ}\right)$; in Fox Mt (avg), 40\% (22\%); in QTb area, average, $\max$ (peaks).

Estimated Avg In Mc, $4 \%\left(2.5^{\circ}\right)$

26. Ridge gradients Included in Mc above. Lengths $\operatorname{Max}-300 \mathrm{~m}\left(1000^{\prime}\right)$ in Mc quartzite

27. Stm gradients $1.5 \%\left(1^{\circ}\right)$ to $\mathrm{E}$ Channel width $\sim 5 \mathrm{~m}\left(15^{\prime}\right)$

28. Dist.-brng to major topo break =-

29. Miscellaneous: Access rte From US 6, turn S (toward Lund) on NV 38 for $\sim 50 \mathrm{mi}$. From Wildlife Refuge turnoff just $\mathrm{N}$ of Gap Mt, continue $7 \mathrm{mi}$ to beginning of roadcut. Turn SW off highway \& through unlocked gate, bear right past gate \& continue. At 1.9 mi cross stream wash \& other road, continue SW. Bear right (to NW) immediately after crossing wash. Mc outcrops begin $\sim 2$ more mi ( $4 \mathrm{mi}$ off highway).

30. Known dril1 holes None

31. Known springs None

32. Mines (active/abandoned) None observed.

33. Prospects/claims None observed.

34. Mineralization/alteration Exposed sandstones in Mc show pervasive red stain \& general oxidation along bedding plane \& fractures.

35. Possible subsurf proj May underlie area of Pe to SW, but other than this, area is mapped as fault (high-angle) bounded.

36. Possible testhole sites -- 
FIELD RECONNAISSANCE CHECKLIST (cont)

Locale Designation NN-5A

Sublocale Name Fox Mt North (FMN)

37. Possible geophysical sites =-

38. Other --

Geologist J. Connol1y

Organization UNM

Date $7 / 13 / 79$ 
FIELD RECONNAISSANCE CHECKLIST

Phase II Investigations: Fine-Crained (fn/grn)

Clastic Sedimentary Rocks and Metamorphic

Derivatives in Eastern Nevada

1. Stratigraphic name/

designator Chainman Shale (Mc)

2. Unit above: $1 \mathrm{ith} /$ thick Ely Limestone ( $\mathbb{P e})$ : med-thick bedded gray limestone

3. Unit below: $1 \mathrm{ith} /$ thick Joanna Limestone $(\mathrm{Mj})$ gray limestone; contact not exp here.

4. Topo maps: $1^{\circ} \times 2^{\circ}$ Lund $15^{\prime}$ Forest Home (part only) 7-1/2' =-

5. Other -Sec (Unsurveyed) Twnship =Range =-

6. Distr-Brng $2438 \mathrm{~m}\left(8000^{\prime}\right)$ due $W$ from $W$ edge $\operatorname{Sec} 31, T 5 N, R 60 E$

7. Exp area \& dimensions $-1.6 \mathrm{~km}^{2}\left(0.6 \mathrm{mi}^{2}\right)$. Area $-1.25 \mathrm{mi}$ long (N-S) by $0.6 \mathrm{mi}$ wide (E-W). Area less than that due to capping of peaks by Ely Limestone $(-2 \mathrm{~km} \times 1 \mathrm{~km})$. \% Bedrock exp $\sim 10$; quartzite dom. exposures; rest covered by limestone \& quartzite float.

8. Stratigraphy (Estimated By foot traverse. Measured =-

9. Unit-thickness exp $2320 \mathrm{~m}\left(1000^{\prime}\right)$ Fn-grn\% Cannot be determined. Perhaps 30. Clay-mineral rich \% Cannot be determined

10. Lat continuity Cannot be determined Induration and Colors Shale obs is dark gray \& thinly fissile.

11. Thickness-clay horizon Unknown.

12. Samples \& locations None

13. Other Lithologies No outcrop of shale found--occasional patches of weathered thinly fissile black shale observed, but digging did not reveal outcrop. Exposure dominated by medium fg quartzite (some somewhat lithic) in lenses and beds up to $15-20 \mathrm{~m}$ thick for est total of $50 \mathrm{~m}$ exposed. Float of siltstone \& dark silty argillite observed locally. These exposures appear to resemble Scotty's Wash quartzite of Kellogg (1963). Dips are generally to $N$ and shale may be more abundant to $S$, but exposures are still very poor. Thickness probably too high since unit appears to be repeated by faulting.

14. "Bedding" N80E, 36N; quartzite-1ithic sandstone lens $\sim 5 \mathrm{~m}$ thick; N60W, 31N quartzite-sandstone base series of sandstone lense $10 \mathrm{~m}$ thick, total $250 \mathrm{~m}$ thick. N65E, 45NW, qzite; N5OE, 55NW 15-20 m thick sandstone lens.

15. Fissl/Cleavage/Foliation One exposure of shale was thinly fissile.

16. Contacts/Boundaries Base Strat base not exposed.

17. Top Ovcrlain by Ely Timestone. Both $\mathbb{P e}$ and Mc are faulted.

18. Other On W, Mc appear to be faulted vs Tsh (Shingle Pass Tuff) \& Qal. On E, is in fault contact with Guilmette Fm (Dg) Limestone.

19. Structure. Best map reference Kleinhamp1 \& 2iony (1967). "Preliminary Geologic Map of Northern Nye County, Nevada," USGS Open File Map; also for stratigraphic discussion, see Kellogg, H. E. (1963). "Paleozoic Stratigraphy of Southern Egan Range, Nevada," Geo1 Soc Am Bulletin 74, PP 685-708. 
FIELD RECONNA ISSANCE CHECKLIST (cont)

Locale Designation $\mathrm{NN}-5 \mathrm{~B}$

Sublocale Name Gorden Valley North

20. Regional Setting Area lies in $\mathbf{N}$ extremity of Golden Gate Range which in this area is a generally $\mathrm{N}$-trending horst block of Tertiary Volcanics \& faulted Mid to Late Paleozoic strata. Thrust faults are strongly subordinate to high-angle faults \& have not been mapped in this part of the range although present to $S$ of area in Lincoln County.

21. Faults Series of WNW-striking high-angle faults. Repeat both Mc and $\mathbb{F e}$.

22. Joints Sandstones are highly fractured, but no mineralized joints or fractures noted.

23. Folds None noted.

24. Topography Area is one of low ridges on $W$ margin of mountainous terrain (underlain by Dg) \& on E margin of White River Valley alluvial fan complex.

25. Slopes, max-min In Mc $24 \%\left(13^{\circ}\right)$ to $17 \%\left(10^{\circ}\right)$. Slopes are very $10 c a 11 y$ higher in areas underlain by thick resistant quartz sandstone ledge. N-trending ridges are usually strike ridges in Pe or Mc \& are 300-900 m (1000-3000') long. E-W-striking ridges, with gentle E slopes, are in overlying Shingle Pass Tuff.

Estimated Avg Can vary within prev given range

26. Ridge gradients Refer to 非25. Lengths --

27. Stm gradients All intermittent, avg $10 \%$, generally $W\left(6^{\circ}\right)$ Channel width $<10 \mathrm{~m}\left(30^{\prime}\right)$

28. Dist.-brng to major topo break Lies on topo break from low hills to Garden Valley on W.

29. Miscellaneous: Access rte From Sunnyside (43 mi s of US 6 on NV 38 ), follow dirt road past Forest Home Ranch $-21 \mathrm{mi}$. From Forest Home Ranch (sign to Teaspoon-Wiregrass Springs). Proceed S $5.1 \mathrm{mi}$. At Scafield Canyon turnoff sign, take left fork continue $\mathrm{S} 1.8 \mathrm{mi}$ to foot of E-W-trending ridge. Make very sharp turn to E. Road turns NE then S through saddle. $2.6 \mathrm{mi}$ from turnoff, fork to $\mathrm{E}$ is unmapped trail. Continue $1 / 2 \mathrm{mi}$ where deadend at wash after coming up a draw. Mc (mostly quartzite) crops out in small hills.

30. Known drill holes None

31. Known springs None; however, local green vegetation suggestive some subsurface seeps.

32. Mines (active/abandoned) None

33. Prospects/claims None

34. Mineralization/alteration None

35. Possible subsurf proj None. Fault bounded on al1 sides outside outcrop area.

36. Possible testhole sites =-

37. Possible geophysical sites =-

38. Other This is part of area of interbasin groundwater flow discussed by Eakin, T. E., (1966). "Interbasin Groundwater Flow in the White River Area, Southeastern Nevada"; Water Res. Research. 2, pP 251-271). Basin is topographically closed but groundwater is suggested to flow out SE into Pahranagat Valley (part of White River Valley). 
FIELD RECONNAISSANCE CHECKLIST

Phase II Investigations: Fine-Grained (fn/grn)

Clastic Sedimentary Rocks and Metamorphic

Derivatives in Eastern Nevada
Locale Designation $\mathrm{NN}-5 \mathrm{C}$

Sublocale Name Gap Mt 2

South

1. Stratigraphic name/

designator Chainman Shale (Mc)

2. Unit above: 1 ith/thick Ely Limestone ( $\mathbb{P e}$ ); gray limestone

3. Unit below: $1 \mathrm{ith} /$ thick Joanna Limestone $(\mathrm{Mj})$; gray 1 imestone, not exposed.here.

4. To po maps: $1^{\circ} \times 2^{\circ}$ Lund $15^{\prime}=-1 / 2^{\prime}$ Gap Mt

5. Other $=-\operatorname{Sec}$ El/2 Sec 25 Twnship 5N Range 61E

6. Distr-Brng =- from $=$

7. Exp area \& dimensions $2.6 \mathrm{~km}^{2}\left(1 \mathrm{mi}^{2}\right)$. Much shale covered by float from resistant sandstones. Max dimensions $-1.1 \mathrm{~km} \times \sim 2.7 \mathrm{~km}(0.7 \mathrm{mi} \times 1.7 \mathrm{mi})$.

\%Bedrock exp $\leq 10$; coarser clastics are preferentially exposed.

8. Stratigraphy (Estimated By foot traverse Measured --

9. Unit-thickness exp 250-350 m (800-1000') Fn-grn\% Very 1ittle clay shale found due to poor exposed rock type is dark grayish green to gray siltstone with thin clayey partings. Clay-mineral rich \%

10. Lat continuity For shale, unknown because of poor exposures. Induration and Colors See item 9.

11. Thickness-clay horizon Unknown

12. Samples \& locations None

13. Other Lithologies Section is perhaps $75 \%$ clayey siltstone (poorly exposed) \& shale (very poorly exposed). Fine to $\mathrm{vfg}$ slightly arkosic quartzites make up remainder. One tabular body $-12 \mathrm{~m}\left(35^{\prime}\right)$ thick is present but most quartzites appear to be small lenses $3-5 \mathrm{~m}$ $\left(10-15^{\prime}\right)$ thick.

14. "Bedding" N30W, 24SW in fg quartzite in tabular bed. Sequence appears to dip homoclinally $20^{\circ}-30^{\circ}$ to $\mathrm{SW}$.

15. Fissl/Cleavage/Foliation Silty shales tend to be fissile with partings spaced $2 \mathrm{~mm}$ or more.

16. Contacts/Boundaries Base Not exposed. Inferred fault strikes $N 25 \mathrm{~W}$ on $\mathrm{N}$ edge of area \& juxtaposes Mc \& Guilamette Fm (1 imestone) (desig. Dg).

17. Top Overlain by Ely Limestone to NW. Unconformably overlain by Shingle Pass Tuff on $W$ \&.

18. Other Locally intruded by Tertiary Volcanics probably related to Shingle Pass Tuff.

19. Structure, Best map reference Kleinhampl \& Ziony (1967). "Preliminary Geologic Map of Northern Nye County, Nevada," USGS Open File Map.

20. Regional Setting Gap Mt \& area to S are areas of low hills that are a structural extension of the Southern Egan Range. Rocks are generally tilted SW \& cut by NNE \& NW-striking highangle faults; thrust faults do not appear to be significant in this area.

21. Faults Inferred NW-striking fault juxtaposing Dg \& Mc on $N$ of area is marked by resistant silicified knobs poking through alluvium. 
FIELD RECONNAISSANCE CHECKLIST (cont)

Locale Designation $\mathrm{NN}-5 \mathrm{C}$

Sublocale Name Gap Mt 2 South

22. Joints Not observed in shale due to poor exposures. Tend to be common at high angle to bedding in quartzite, closest spacing $6-12 / \mathrm{m}$.

23. Folds None observed.

24. Topography Exposures are in low hills on $W$ edge of pediment-fan complex to E.

25. Slopes, max $\min$ Exposure areas, $9 \%\left(5^{\circ}\right)$ to $5 \%\left(3^{\circ}\right)$; pediment-fan, $3-4 \%\left(2^{\circ}\right)$ Estimated Avg =-

26. Ridge gradients Quartzite strike ridges in Mc--max $35 \%\left(19^{\circ}\right)$ perpendicular to strike. Lengths $\operatorname{Max} 500 \mathrm{~m}\left(1500^{\prime}\right)$

27. Stm gradients Major intermittent stream $3 \%\left(2^{\circ}\right)$ Channel width $20 \mathrm{~m}\left(50^{\prime}\right)$.

28. Dist.-brng to major topo break Lies on topographic break (Item 24 above).

29. Miscellaneous: Access rte From Jct NV 38 \& US 6 , proceed S -38.5 mi to Wildlife Refuge turnoff. Continue $S$ on NV $382.3 \mathrm{mi}$, turn WSW on unmaintained dirt road (through gate) $\sim 1.8$ mi. Bear $S \sim 1.0 \mathrm{mi}$ along ridge front, then $0.3 \mathrm{mi}$ due $W$ on unmaintained trail skirting $N$ shoulder of wash. Mc outcrops in low hills \& strike ridge on S side of wash.

30. Known drill holes None noted

31. Known springs None noted; none shown on Gap Mt Quad. $\left(7-1 / 2^{\prime}\right)$

32. Mines (active/abandoned) None

33. Prospects/claims No claims stakes noted in area.

34. Mineralization/alteration Some silicification-oxidation noted along fault on NE boundary; no pervasive alteration noted.

35. Possible. subsurf proj

36. Possible test-hole sites Clear fault margin not present to E \& SE \& topography suggests shale may continue under valley to SE. May be good test hole site.

37. Possible geophysical sites Gravity traverse may help delineate fault (Items 35 \& 36 ).

38. Other =-

Geologist J. Connolly Organization UNM Date $5 / 20 / 79$ 
FIELD RECONNAISSANCE CHECKLIST

Phase II Investigations: Fine-Grained ( $\mathrm{fn} / \mathrm{grn}$ )

Locale Designation NN-5D

Clastic Sedimentary Rocks and Metamorphic

Derivatives in Eastern Nevada

Sublocale Name Gap Mt 1

South

1. Stratigraphic name/

designator Chainman Shale (Mc)

2. Unit above: lith/thick Ely Limestone ( $\mathbb{P e ) ; ~ m a s s i v e - m e d ~ b e d d e d ~ l i m e s t o n e , ~ m o s t l y ~ m e d ~ g r a y . ~}$

3. Unit below: $1 \mathrm{ith} /$ thick Joanna Limestone $(\mathrm{Mj})$, not exposed here. Is in fault contact in $W$. Devil's Gate Limestone $\left(D_{g}\right)$ on NE. $\mathrm{Dg}$ is in darker gray than Pe \& generally much more fossiliferous (bryozoans, brachiopods, corals).

4. Topo maps: $1^{\circ} \times 2^{\circ}$ Lund $15^{\prime}$ Not surveyed 7-1/2' Gap Mt

5. Other $=$ Sec $=-$ Twnship Range --

6. Distr-Brng 300-4400', S40E from $\mathrm{NE}$ corner $\mathrm{Sec} 13, \mathrm{~T} 5 \mathrm{~N}, \mathrm{R} 61 \mathrm{E}$

7. Exp area \& dimensions $-4100^{\prime}$ long (NW) $\times 1000^{\prime}$ wide (SW). Area $\sim 0.4 \mathrm{~km}^{2}\left(0.15 \mathrm{mi}^{2}\right)$. \%Bedrock exp $\sim 10$; most covered by limestone float.

8. Stratigraphy (Estimated By foot traverse $\&$ mapping Measured --

9. Unit-thickness exp $\simeq 100 \mathrm{~m}\left(300^{\prime}\right)$. A1l estimates very equivocal since based on very 1 imited outcrop.

Fn-grn\% $\sim 75$ Clay-mineral rich \% $\sim 60$ ?

10. Lat continuity Cannot be estimated because of poor exposure. Shales are frequently brittle (particularly flaggier types) but some clay-rich thinly fissile types are fairly soft Induration and Colors Usually dark gray to black, occ. greenish weathers 1 ight gray.

11. Thickness-clay horizon Perhaps 200'; poor exposures difficult to estimate.

12. Samples \& locations GMl from Mc platy to flaggy shale. Locale $1100^{\prime}$ S58E from NE corner Sec 13, T5N, R61E.

13. Other Lithologies Rare vfg sandstone \& siltstone is found in section, chiefly near contact with Pe \& dark nodules of chert are found locally. Limestone float is abundant but none is in place \& this may be let down from erosion of overlying $\mathbb{P e}$.

14. "Bedding" N48W, 16NE Mc shale near volcanics; N37W, 53W in Dg (of Gap Mt) NE of Mc N53E, $13 \mathrm{NW}$ in Mc shale; N52W, 17NE in Mc shale.

15. Fissl/Cleavage/Foliation Shales are highly fissile to flaggy $(-1 / 2-1 \mathrm{~cm})$. Strat. lowest exposure most fissile. Strike ridges of sandstone suggest this fissility is bedding.

16. Contacts/Boundaries Base Stratigraphic base not exposed due to fault with Dg.

17. Top Conformably overlain by $\mathbb{P e}$ although contact appears to be locally faulted.

18. Other In fault contact with Guilmette Limestone (Dg) on NE, overlapped by pediment \& alluvium on SE. Locally intruded by gz latite dike or sill (TV) on $W$ end of area. This intrusion locally brecciates Pe \& has apparently produced local patchy alteration of Mc to reddish micaceous argillite; dilation as occurred around intrusives in Mc \& alteration is common.

19. Structure. Best map reference Kleinhampl \& Ziony (1967). "Prelim. Geol. Map of Northern Nye County, Nevada," USGS Open File Map. 
FIELD RECONNAISSANCE CHECKLIST (cont)

Locale Designation NN-5D

Sublocale Name Gap Mt 1 South

20. Regional Setting Gap Mt \& Fox Mt areas are a topographic extension of the southern Egan Range; however, tilt of beds is to $W$ or NNW \& high-angle faults. of NW \& NNE trend dominate the area. Thrust faults are not mapped by Kleinhampl \& Ziony. Largely homoclinal sequences broken by high-angle faults appear to doninate. Exposures here are good for the area but not very complete.

21. Faults W, Dg on NE, N50W, 75SW, locally hematitic \& silicified, locally with breccia zones in $\mathrm{Dg}$ (?). Local alteration \& brecciated $\mathbb{P e}$ on $W$ appears to be related to forcible intrusion of $q z$ latite dikes.

22. Joints Mc is highly fractured at high angle to bedding. Dg \& Pe are highly fractured near faults \& intrusions.

23. Folds Except near intrusives, Mc appears to dip gently NE. Pe dips gently to moderately SW suggesting "conformable" contact may be a fault of some sort.

24. Topography Mc exposures are in NW-striking saddle SW of Gap Mt \& $N$ of hilly terrain to S.

25. Slopes, max-min In Mc $20 \%\left(11^{\circ}\right)$ to $16 \%\left(9^{\circ}\right)$; in Me up to $50 \%\left(27^{\circ}\right)$, Gap Mt up to $40 \%\left(21^{\circ}\right)$ Estimated Avg $18 \%\left(10^{\circ}\right)$ in Mc; steeper on SW.

26. Ridge gradients NA Lengths =-

27. Stm gradients $4 \%\left(2.3^{\circ}\right)$ to $\mathrm{NW}$ Channel wid.th $7 \mathrm{~m}\left(20^{\prime}\right)$

28. Dist.-brng to major topo break Lies on NW edge of alluvial valley to SE.

29. Miscellaneous: Access rte From US 6 , turn $S-50 \mathrm{mi}$ on NV 38 . Continue $2.2 \mathrm{mi} \mathrm{S}$ from Wayne Kirsch Wildlife Refuge turnoff (just $N$ of Gap Mt). Turn SW on dirt trail $\sim 2.1 \mathrm{mi}$ bearing to right through saddle SW of Gap Mt; Mc outcrops in saddle.

30. Known drill holes None

31. Known springs None

32. Mines (active/abandoned) None

33. Prospects/claims None noted

34. Mineralization/alteration Mc is locally red, stained, and slaty, apparantly related to volcanic intrusion. Limestones are locally silicified \& red-stained near faults.

35. Possible subsurf proj May project to SW \& SE under Pe \& Qal if sequence conformable.

36. Possible testhole sites --

37. Possible geophysical sites =-

38. Other --

Geologist J. Connolly Organization UNM Date $7 / 13 / 79$ 
FIELD RECONNAISSANCE CHECKLIST

Phase II Investigations: Fine-Grained (fn/grn)

Locale Designation NN-6A

Clastic Sedimentary Rocks and Metamorphic

Derivatives in Eastern Nevada

Sublocale Name Teaspoon Spring

1. Stratigraphic name/

designator Chainman Shale (Mc)

2. Unit above: $1 \mathrm{ith} /$ thick Ely Limestone ( $\mathbb{P e}$ ); thin-to thick-bedded, med gray, foss limestone with abundant brachiopods.

3. Unit below: 1 ith/thick Joanna Limestone $(M j)$ : gen. fg, med gray to dark gray, med-bedded crinoidal limestone.

4. Topo maps: $1^{\circ} \times 2^{\circ}$ Lund 15' Forest Home $-7-1 / 2^{\prime}=$

5. Other -Sec Area not surveyed Twnship =Range =-

6. Distr-Brng Between $-600-1800 \mathrm{~m}\left(2000-5800^{\prime}\right) \mathrm{s} 37 \mathrm{~W}$ from NW corner $\operatorname{Sec} 30 \mathrm{~T} 6 \mathrm{~N}, \mathrm{R} 59 \mathrm{E}$

7. Exp area \& dimensions $22.2 \mathrm{~km}^{2}\left(0.85 \mathrm{mi}^{2}\right)$. Approximate dimensions (max) $2.3 \mathrm{~km}$ (ENE) $\mathrm{x}$ 0.8 (NNW) $(1.4 \mathrm{mi} \times 0.5 \mathrm{mi})$. Dominance of shale is indicated by fact that wherever shale is seen at surface, digging reveals bedrock exp of shale, while no bedrock siltstone or sandstone exposures could be found.

\%Bedrock exp $\sim 20$. Most covered by 1 imestone \& siltstone float.

8. Stratigraphy (Estimated By foot traverse with map. Measured --

9. Unit-thickness exp $\simeq 500 \mathrm{~m}\left(1500^{\prime}\right)$ Fn-grn\% $\sim 80 \quad$ Clay-mineral rich $\% \simeq 60$

10. Lat. continuity Difficult to estimate but most bedrock exp. are fg. Induration and. Colors Generally soft dark-gray clay shale, some dark flaggy shale \& lesser brown silty shale (sample).

11. Thickness-clay horizon Cannot be determined but sequence appears strongly shale dominated.

12. Samples \& locations TS-1-silty brown shale in Mc (This is not typical shale--see sample for Forest Home Spring Area (FHS-1))

13. Other Lithologies Appear strongly subordinate to shale. Siltstone \& silty brown shale appear to be most abundant, perhaps $20 \%$ of section, some med-fg, wel1-rounded, well-sorted slightly lithic quartz sandstone is present in silty, parts, perhaps $10 \%$. A trace of 1 imestone is present ( $\operatorname{see} \operatorname{Sec} 16,17,18$ ). Limestone is coarsely crystalline \& somewhat dolomitic, perhaps a few \%. Float of felsic volcanic tuff is found in NE part of area.

14. "Bedding" N40E, 24SE in Dg (?) upper plate of thrust; N18E, 40E Mc shale brown silty N50E, 53E shale Mc; N55E, 16SE in Mj (?) limestone in Mc outcrop area; N33E, 33SE in Mc shale; N90E, 27S Mc shale.

15. Fissl/Cleavage/Foliation Shale is generally thinly fissile sometimes flaggy ( $1 / 2-1 \mathrm{~cm})$. Since no nonshale outcrops observed, cannot be determined whether bedding or not.

16. Contacts/Boundaries Base Strat base not exposed.

17. Top Strat top not exposed.

18. Other See Item 20 for discussion of fault contact relations. "Tongues" of Joanna Limestone (Mj) "project" from W beneath fault into Mc outcrop but contact is not clearly exposed--Mj is highly fractured crinoid rich limestone with several chert horizons--suggests possible thrust contact especially since $M j$ is topographically higher than Mc. 
FIELD RECONNAISSANCE CHECKLIST (cont)

Locale Designation NN-6A

Sublocale Name Teaspoon Spring

19. Structure. Best map reference Kleinhampl \& Ziony (1967). "Preliminary Geologic Map of Northern Nye County, Nevada," USGS Open File Map.

20. Regional Setting Area is in part of Southern Central Grant Range--most of range is characterized by normal faulting of homoclinal sequences in upper \& mid Paleozoic rocks \& thrust faults in lower $\mathrm{Pz}$. In this area, $\mathrm{K} \& \mathrm{Z}$ map a thrust contact with ordovician-Devonian Limestones (Guilmette Fm, Levy Dolomite, Simonsen Dolomite, Ely Spr \& Laketown Dol., Eureka Qzite \& Pogonip Group) in upper plate \& Joanna Limestone, Chainman Shale \& Ely Limestone in lower plate.

21. Faults $M j$ may be in local thrust contact with Mc (see Item 18); no clearly exposed faults observed within Mc.

22. Joints Guilmette Fm (Dg) in thrust contact with Mc shows extensive calcite-filled joints \& brecciation zones of low SE dip (parallel bedding) that are related to faulting. Similar calcite-filled joints are present (as well as a thick chertified zone) in Mj above Mc supporting thrust possibility.

23. Folds None observed in Mc but variation of strike \& dip suggest internal folding.

24. Topography Mc outcrops in area of very low ridges in "amphitheater" like area NE of the Horse Spring Hills, which are underlain by limestone.

25. Slopes, max-min In Mc, $10 \%-8 \%\left(6^{\circ}-5^{\circ}\right)$; in Horse Spring Hi11s, $40 \%-30 \%\left(22^{\circ}-17^{\circ}\right)$. Est imated Avg In Mc-9\% $\left(5^{\circ}\right)$

26. Ridge, gradients Included in Mc range above. Lengths $\operatorname{Max} \sim 500 \mathrm{~m}\left(1500^{\prime}\right)$

27. Stm gradients Teaspoon Wash $4 \%\left(2.3^{\circ}\right)$ to $\mathrm{NE}$. Channel width $\sim 5 \mathrm{~m}\left(15^{\prime}\right)$

28. Dist.-brng to major topo break $\sim 1 \mathrm{mi}$ due E to start of Qal of Big Spr Wash which grades imperceptibly eastward without topo break to alluvial fans of White River Valley.

29. Miscellaneous: Access rte From NV 38 at Sunnyside ( $43 \mathrm{mi} \mathrm{S}$ of US 6), go $8.6 \mathrm{mi}$ on Forest Moon-Forest Home Road (BLM sign) (wel1-graded road); bear right past Forest Moon \& continue $9.3 \mathrm{mi}$ to Forest Home turnoff. Signs lead to Teaspoon Spring Road; proceed SW $1.4 \mathrm{mi}, \mathrm{bear}$ $W$ at fork \& cont inue $1.4 \mathrm{mi}$ where road to Mt Spring bears off to $\mathrm{S}$. Continue $\mathrm{W}$ (in $\sim 1 \mathrm{mi}$ road enters wash \& becomes a narrow trail). $2.4 \mathrm{mi}$ from Mt Spring turnoff, trail forks. Right fork leads to Wiregrass Spring, left fork leads in $0.8 \mathrm{mi}$ to Teaspoon Spring. 4WD not needed, but narrow vehicle helpful.

30. Known drill holes None

31. Known springs Both Wiregrass \& Teaspoon Springs issue from Limestone in upper plate of thrust with Mc. Teaspoon Spring has surface flow of about 20 drops per minute (a teaspoonful) but local patches of grasses \& very green vegetation in Mc area suggest much "underflow" within colluvial cover from springs.

32. Mines (active/abandoned) None

33. Prospects/claims None observed; some red flagging on trees on trail in, but may not be related to mineral activity. 
FIELD RECONNAISSANCE CHECKLIST (cont)

Locale Designation NN-6A

Sublocale Name Teaspoon Spring

34. Mineralization/alteration None observed in Mc. Devonian Limestones show very minor yellow stain in breccia zones near faults.

35. Possible subsurf proj Probably none except for narrow alluviated area between here \& Forest Home Spring, locality beneath Ely Limestone.

36. Possible testhole sites None

37. Possible geophysical sites None

38. Other Iand shown as part of Humboldt National Forest.

Geologist J. Connolly Organization UNM Date $7 / 15 / 79$ 
FIELD RECONNAISSANCE CHịCKLIST

Phase II Investigations: Fine-Grained (fn/grn)

Clastic Sedimentary Rocks and Metamorphic

Derivatives in Eastern Nevada
Locale Designation NN-6B

Sublocale Name Forest Home Spring

1. Stratigraphic name/

designator Chainman Shale (Mc)

2. Unit above: lith/thick Ely Limestone (Pe)

3. Unit below: 1 ith/thick Joanna Limestone (Mj)

4. Topo maps: $1^{\circ} \times 2^{\circ}$ Lund $15^{\prime}$ Forest Home 7-1/2

5. Other -- Sec El/2 Sec 18, E1/2 Sec 1, E1/2 Sec 6, W1/2 Sec 5 Twnship 6N Range 59E

6. Distr-Brng =from =-

7. Exp area \& dimensions $\sim 2.9 \mathrm{~km}^{2}\left(1.1 \mathrm{mi}^{2}\right) . \operatorname{Max} 8 \mathrm{~km}$ (NNE) $0.5 \mathrm{~km}$ (EW) 1 ong (5 mi $10 \mathrm{ong} \times$ $0.3 \mathrm{mi}$ ).

\% Bedrock exp 10. Mostly covered by 1 imestone float.

8. Stratigraphy (Estimated By traverse with map Measured --

9. Unit-thickness exp $\sim 400 \mathrm{~m},\left(1200^{\prime}\right)$ Fn-grn\% 60. Exposures not sufficient to determine percentages with any precision. These estimates based on extrapolation of dip \& outcrop maximum width for thickness. When quartzite is present in sequences, shale generally crops out very poorly. Best shale exposures are to $E$ of Spring. Clay-mineral rich \% 50 ?

10. Lat continuity Appears good E of spring but "upper" part contains much quartzite. Shale is generally fairly soft; occasionally limey shales are brittle. Weathers to thin platelets. Induration and Colors Shale is dark gray to black, rarely greenish, weathers to greenish, brown soil.

11. Thickness-clay horizon Difficult to estimate; as much as $800-1000^{\prime}$ may be present $\mathrm{E}$ of spring.

12. Samples \& locations (NN-6) FHS1-Mc shale from $-50 \mathrm{~m}$ E of Forest Home Spring (N37E, 60E)

13. Other Lithologies Clay shale appears to dominate lower part of section; highly calcareous shale is present but quantity unknown in lower part. Is dark \& tends to be flaggy. Uppet part contains significant quartzite lenses $\& /$ or beds. $1-4 \mathrm{~m}$ thick. (Best exposure $\mathrm{S}$ of Spring.) Grades upward into Pe by appearence of ledge-forming limestone beds.

14. "Bedding" N58W, 14NE in Mj below Mc; N84E, 10S in Mc qzite $2 \mathrm{~m}$ thick; N70W, 32S in ridge of $\mathbb{P e}$ near top of Mc; N60E, $50 \mathrm{~S}$ in Mc qzite, $3 \mathrm{~m}$ thick; N37E, 60E Wash, E at Spring; N60E, 27E adj to previous N55E, 40SE bedding \& breccia zone in Mc qzite--grav. slide fault with $\mathbb{P e}$.

15. Fiss1/Cleavage/Foliation Generally very fissile to thinly slabby or flaggy (1 cm thick).

16. Contacts/Boundaries Base Not exposed; see Item 18

17. Top Appears to grade upward into Pe through a series of limestone ledges in shale \& siltstone. Upper part of Mc below limestone ledge includes several thin $(-1-2 \mathrm{~m}$ or less) lenses of grayish to brownigh fg quartzite. 
FIELD RECONNAISSANCE CHECKLIST (cont)

Locale Designation $\mathrm{NN}-6 \mathrm{~B}$

Sublocale Name Forest Home Spring

18. Other Contact with Joanna Limestone appears to be subhorizontal to gently dipping W. Mj topographically higher than Mc; exposures are poor but geometry and location of spring suggests possible thrust (?) fault contact (series of photos. View approx N20E; Spring where abundant deciduous trees. Hogback in Pe. Mj in low ridgy area to W of Spring. Mj-Mc contact is poorly exposed.)

19. Structure. Best map reference Kleinhampl \& Ziony (1967). "Preliminary Geologic Map of Northern Nye County, Nevada," USGS Open File Map; also Hyde \& Huttrer, (1970). "Geology of Central Grant Range, Nevada," AAPG Bulletin, p 503-521, Figure 4 (scale 1:90,000). There is conflict on maps. Kleinhampl \& Ziony show Joanna Limestone (Mj) W of Mc outcrop. This is shown as Ely Limestone ( Pe) on Huttrer's Map.

20. Regional Setting Area lies on E margin of Central Grant Range. Range is characterized by both thrust \& normal faults. Thrust faults are most abundant in rocks older than Devonian. Normal faults tend to show both a northerly strike \& an easterly strike. Exposures of upper Paleozoic rocks tend to occur in northerly striking, generally E-dipping "homoclinal" sequences, although smaller scale structures tend to be more complex.

21. Faults Area to $W$ of spring appears to be low angle (thrust ?) fault with Mjas discussed in Item 18. On NE edge of area, breccia zone parallel to bedding in Me \& Pe suggests that gravity slide type thrust is present between Mc \& $\mathrm{Pe}$.

22. Joints All rock units except Mc are highly fractured as are quartzites in Mc. Mj-Mc contact W of spring shows systematic conjugate joints filled with calcite. Orientation appears to be $\rightleftharpoons$ N2OE, steep.

23. Folds No large folds observed, but variation of strike in Mc near spring suggests considerable small-scale folding is hidden within Mc.

24. Topography Mc exposures form a topographic low area with isolated small ridges between more mountainous terrain on $W \&$ isolated hills on E $80^{\prime}$ contours on Forest Home Quad make slopes fairly crude estimates.

25. Slopes, max-min In Mc (upper part)(max), $80 \%\left(38^{\circ}\right) ;$ near $\operatorname{spring}(\min ), 4 \%\left(2^{\circ}\right)$. Estimated Avg $10 \%\left(6^{\circ}\right)$ in Mc shale.

26. Ridge gradients Avg $16 \%\left(9^{\circ}\right)$ in quartzite' ridges. Lengths $2000^{\prime} \max$

27. Stm gradients $4 \%\left(2^{\circ}\right)$ to E in Forest Home Creek_Channel width $100 \mathrm{~m}\left(300^{\prime}\right)$

28. Dist.-brng to major topo break $\sim 3000 \mathrm{~m}$ (9000') E to alluvial apron of White River Valley.

29. Miscellaneous: Access rte From NV 38 at Sunnyside ( $43 \mathrm{mi}$ s of US 6), go $8.6 \mathrm{mi}$ on Forest Moon-Forest Home road (well-graded dirt-gravel); here bear right (Forest Moon Ranch to left) \& continue $9.3 \mathrm{mi}$ to Forest Home Ranch turnoff. Go through Forest Home Gate (N) \& follow fenceline $E$ then $W$ at corner. Proc. N $1 / 2 \mathrm{mi}$ through gate \& immediately turn left (W) on dirt road. Stay on main dirt road for $3.1 \mathrm{mi}$ until spring at head of Forest Home Creek (avoid numerous branching trails off to left). Mc exposed to E, N\& SW of spring. 
FIELD RECONNAISSANCE CHECKLIST (cont)

Locale Designation NN-6B

Sublocale Name Forest Home Spring

30. Known drill holes None

31. Known springs Spring (here named Forest Home Spring) flows at perhaps $70-100$ gal/min \& feeds Forest Home Creek (perennial). Appears to issue from near Mc-Mj contact within Mc.

32. Mines (active/abandoned) None

33. Prospects/claims one possible old claim post noted; no recent activity.

34. Mineralization/alteration None noted.

35. Possible subsurf proj May underlie Mj in struct cont to $W$; strat may underlie Pe to E.

36. Possible testhole sites --

37. Possible geophysical sites --

38. Other --

Geologist J. Connolly Organization UNM Date $7 / 14 / 79$ 
FIELD RECONNAISSANCE CHECKLIST

Phase II Investigations: Fine-Grained ( $\mathrm{fn} / \mathrm{grn}$ )

Clastic Sedimentary Rocks and Metamorphic

Derivatives in Eastern Nevada
Locale Designation $\mathrm{NN}-6 \mathrm{C}$

Sublocale Name Uhalde

Ranch

1. Stratigraphic name/

designator Ninemile Fm of Pogonip Group (Opn). Above the Pogonip Group: Eureka Qzite (Oe): massive white, pure, ledge forming gzite. Below the Pogonip Group: Windfall Fm ( $6 \mathrm{w})$ : thinbedded limestone \& chert.

2. Unit above: lith/thick Antelope Valley Limestone of Pogonip Group (Opa) thick-bedded to thin-bedded gray limestone, loc. silty.

3. Unit below: $1 \mathrm{ith} /$ thick Goodwin Fm of Pogonip GP (Opg) thick-bedded to massive gray limestone with local cherty horizons.

4. Topo maps: $1^{\circ} \times 2^{\circ}$ Lund. Part of Lund sheet blown up to $1: 62,500$ is included in Sainsbury \& Kleinhampl (1969) with geology shown. $15^{\prime}=$

5. Other -Sec Not surveyed Twnship =Range =-

6. Distr-Brng 3000-5000 m (10 000'-18 000') S80E from Adaven, along Cherry Creek

7. Exp area \& dimensions All Pogonip outcrop $\sim 5 \mathrm{mi}(\mathrm{N}-\mathrm{S}) \times 1 \mathrm{mi}(\mathrm{E}-\mathrm{W}) \cdot \operatorname{Area}^{2}-13 \mathrm{~km}^{2}\left(5 \mathrm{mi}^{2}\right)$ $\%$ Bedrock exp $\simeq 40$ in 0 pn.

8. Stratigraphy (Estimated By foot traverse. Measured --

9. Unit-thickness exp $\sim 500^{\prime}$ Opn Fn-grn\% $\simeq 50$ Clay-mineral rich \% $\sim 15$

10. Lat continuity Appears to be poor for shaley rocks.

Induration and colors Soft, poorly indurated brownish gray; greenish \& gray.

11. Thickness-clay horizon (?) Poorly exposed.

12. Samples \& locations None taken.

13. Other Lithologies Opn consists of dominantly thin-bedded "crinkly" beds of shelly limestone, generally brownish gray with interbedded silty limestone \& calcareous siltstone, generally buff weathering.

14. "Bedding" Strike generally $\sim$ N20W with dips gently to moderate $\left(0^{\circ}-60^{\circ}\right) E \& W$ on flanks of folds.

15. Fissl/Cleavage/Foliation One weathered shale outcrop observed--weathers into thin platelets

16. Contacts/Boundaries Base Both appear conformable \& gradational between 0pg-0pn-0pa.

17. Top 6w not exposed.

18. Other 0e caps entire Op seguence, apparently conformably. Devonian \& Silurian beds overlie Op on $W$ in low-angle fault contact, 0 e is faulted with Qal \& pediment on $E$ in mouth of Cherry Creek Canyon.

19. Structure. Best map reference Kleinhampl \& Ziony (1967). "Preliminary Geol. Map of Northern Nye County, Nevada," USGS Open File Map $(1: 200,000)$ : B lowup of earlier edition. this map (showing more otructural data) at scale of $1: 62,500$ is included in Sainsbury, C. L \& Kleinhamp1, R. M., (1969). "Fluorite Deposits of the Quinn Canyon Range, Nevada," USGS Bulletin 1272-C, 22p. 
FIELD RECONNAISSANCE CHECKLIST (cont)

Locale Designation NN-6C

Sublocale Name Uhalde Ranch

20. Regional Setting Area lies on E flank of Quinn Canyon Range. Area characterized by older (possibly ENE yielding) thrust faults, extensive cover of Tertiary Volcanics (with "windows" through which palaenzoic rocks are exposed) \& northerly trending high-angle faults that cut rocks as young as Quarternary (?) alluvium.

21. Faults Fault at mouth of Cherry Creek is well-exposed W. Oe juxtaposed with Quaternary Boulder beds.

22. Joints Not observed.

23. Folds Numerous small-scale folds are most obvious in thin-bedded limestone, tend to parallel mapped N20W-trending large-scale folds.

24. Topography $0 p$ is exposed in steep-walled canyon (E-W) of Cherry Creek Canyon wa11 exposures generally inaccessible; surrounding terrain mountainous.

25. Slopes, max-min In canyon Opn slopes, $-20 \%\left(11^{\circ}\right)$; other Opn s1opes, $-40 \%\left(22^{\circ}\right)$

Estimated Avg $-30 \%\left(17^{\circ}\right)$

26. Ridge gradients NA Lengths NA

27. Stm gradients Cherry Creek to E 2.5\% (1.5\%) Channel width 150-300 m (500-1000')

28. Dist.-brng to major topo break E edge of area lies on break between Quinn Canyon Range \& pediment alluvium of White River Valley.

29. Miscellaneous: Access rte From Sunnyside on NV $38(-43 \mathrm{mi} S$ of US 6$)$, go $\sim 4 \mathrm{mi}$ SSE on well-graded dirt road to road junction at mouth of Cherry Creek (road signs SE to Hiko etc). Follow signs to Cherry Creek \& Adaven. Continue $W$ up canyon. Oe exp at mouth of canyon, $O p$ exposed in area mostly $E$ of first ranch (Uhalde).

30. Known drill holes None noted. May be present in s part of area due to mining activity.

31. Known springs Abundant subsurface springs feed Cherry Creek \& are used for widespread irrigation of Uhalde Ranch area.

32. Mines (activé/abandoned) No present activity noted.

33. Prospects/claims Several abandoned prospects in Cherry Creek Canyon. Several base-metal ( $\mathrm{Ag}$, galena, tetrahedrite) prospects are located in 0 pa $\mathrm{N} \& \mathrm{~S}$ of Cherry Creek.

34. Mineralization/alteration Aside from some silicification \& oxidation (reddish) none noted in area.

35. Possible subsurf proj May underlie some of volcanics in range to E.

36. Possible testhole sites None

37. Possible geophysical sites None

38. Other Both Uhalde \& Adaven Ranches are large, year-round, residential operations. 
1. Stratigraphic name/

designator Ninemile Fm of Pogonip Group (Opn)

2. Unit above: lith/thick Antelope Valley Limestone of Pogonip Gp (Opa); recryst. loc foss limestone.

3. Unit below: lith/thick Goodwin Fm of Pogonip Gp (Opg); fossiliferous massive limestone.

4. Topo maps: $1^{\circ} \times 2^{\circ}$ Lund $15^{\prime}$ Troy Canyon $7-1 / 2^{\prime}=$

5. Other $=-\operatorname{Sec} \mathrm{N} 1 / 2 \operatorname{Sec} 27 \& \operatorname{S1} 12 \operatorname{Sec} 22 \quad$ Twnship $5 \mathrm{~N}$ Range $56 \mathrm{E}$

6. Distr-Brng $\approx 6.4 \mathrm{~km}(4 \mathrm{mi})$ N65E from Nyala Ranch

7. Exp area \& dimensions $\sim 0.6 \mathrm{~km}^{2}\left(0.25 \mathrm{mi}^{2}\right)$. Area dimensions, $\sim 1.3 \mathrm{~km}(\mathrm{NE}) \times 0.6 \mathrm{~km}(\mathrm{NW})$ $(0.8 \mathrm{mi} \times 0.4 \mathrm{mi})$.

\% Bedrock exp $\sim 50$; rest covered by float.

8. Stratigraphy (Estimated Total by traverse; 0pn thickness paced \& calculated. Measured $=-$ )

9. Unit-thickness exp 0 pn, $60 \mathrm{~m}\left(200^{\prime}\right)$ Fn-grn\% $\simeq 40 \quad$ Clay-mineral rich $\% \simeq 25$

10. Lat continuity Poor Induration and Colors Shale generally soft. Varies from light gray to green (glauconitic ?)

11. Thickness-clay horizon Unknown but tabular beds of any single lithology appear rare.

12. Samples \& locations None

13. Other Lithologies Exposed Pogonip Group thickness exceeds $600 \mathrm{~m}$ (2000'). Shale interval (Opn) contains abundant thin lenses of detrital fossiliferous limestone ("death" assemblage of shel1 fragments) as well as abundant "Receptaculites" that appear in place within shale.

14. "Bedding" N.35W, 40NE in overlying Eureka Qzite \& Pogonip Group. Sequence is a NE-tilted homocline.

15. Fiss $1 / \mathrm{Cleavage/Foliation} \mathrm{Shales} \mathrm{are} \mathrm{fissile} \mathrm{\&} \mathrm{break} \mathrm{\&} \mathrm{weather} \mathrm{into} \mathrm{thin} \mathrm{shale} \mathrm{platelets.}$

16. Contacts/Boundaries Base Conformable with Opg; gradational.

17. Top Gradational \& conformable with Opa.

18, Other Surrounded \& overlapped by pediment gravels ( $Q P$ ).

19. Structure. Best map reference Kleinhampl \& Ziony (1967). "Prelim. Geol. Map of Northern Nye County, Nevada," USGS Open File Map; al so shown at large scale $(1: 62,500$-blown up from Kleinhampl \& Ziony) in Sainsbury \& Kleinhamp1 (1969). "Fluorite Deposits of the Quinn Canyon Range, Nevada," USGS Geol. Survey Bullet in 1272-C.

20. Regional Setting Area lies within pediment-alluvium reentrant that topographically separates the Quinn Canyon Range from the southern Grant Range. Both ranges are fault block ranges, generally SE- to E-tilted internally modified by low-angle faults, granitic intrusion, high-angle faults \& Tertiary volcanics. 
FIELD RECONNAISSANCE CHECKLIST (cont)

Locale Designation NN-6D

Sublocale Name ox sping Wash

21. Faults None observed within Pogonip outcrop area. Pediment-bedrock fault in range mapped with NNE strike $-2 \mathrm{mi}$ to $\mathrm{SE}$. Pediment topographically terminated $\sim 2 \mathrm{mi}$ to NW with similar strike. May be a fault. Scattered outcrops of $0 p-0 e$ \& other strata within pediment in $\&$ around $0 x$ Spring \& wash strongly suggests much concealed faulting because of highly variable orientation of exposures (see map, Plate 1 in. Sainsbury \& Kleinhamp1, 1969).

22. Joints Limestones (particularly Opa) are highly fractured \& recryst. generally at high angle to bedding.

23. Folds None observed in Op. Sequence is a NE-dipping homocline.

24. Topography Op outcrops are in monadnock within pediment surface. Rugged front of GrantQuinn Canyon Range lies $\sim 2 \mathrm{mi}$ to $\mathrm{E}$.

25. Slopes, max-min In outcrop area (steepest on W side), $50 \%-20 \%\left(27^{\circ}-11^{\circ}\right)$; in pediment to $W$, $6.4 \%-4.3 \%\left(3.6^{\circ}-2.4^{\circ}\right)$

Estimated Avg Range given prev.

26. Ridge gradients $\mathrm{NA}$ Lengths =-

27. Stm gradients Major, ox Spr. Wash, $3 \%\left(1.7^{\circ}\right)$ to $W$; minor stms. same as pediment. Channel width 300-500' (Ox Spr Wash)

28. Dist.-brng to major topo break $2 \mathrm{mi}$ NW to pediment edge; $2 \mathrm{mi}$ SE to range.

29. Miscellaneous: Access rte From Junction of NV 25 \& road (marked) to Nyala Ranch, proceed $22.5 \mathrm{mi} \mathrm{NE}$ to Nyala Ranch. From ranch, continue $2.6 \mathrm{mi} \mathrm{NE}$ to junction with graded dirt road (sign to Adaven \& Cherry Creek Summit). Turn E $-1.8 \mathrm{mi}$. Op outcrops are in low hills to s.

30. Known drill holes None

31. Known springs None in area. Several (incl Ox Spr) mapped in range $-2-1 / 2 \mathrm{mi}$ to $\mathrm{E}$.

32. Mines (active/abandoned) None

33: Prospects/claims None noted

34. Mineralization/alteration None noted.

35. Possible subsurf proj Pogonip probably underlies much of pediment but does not contain any homogenous shales or argillites.

36. Possible testhole sites None

37. Possible geophysical sites None

38. Other =-

Geologist J. Connolly Organization UNM Date $5 / 22 / 79$ 
FIELD RECONNAISSANCE CHECKLIST

Phase II Investigations: Fine-Grained (fn/grn)

$\mathrm{Cl}$ astic Sedimentary Rocks and Metamorphic

Derivatives in Eastern Nevada

1. Stratigraphic name/

designator Pioche Shale ( $6 \mathrm{p}$ )

2. Unit above: $1 \mathrm{ith} /$ thick Eldorado Limestone (6e) Thin-bedded silty to argillaceous limestone, metamorphosed to slaty limestone.

3. Unit below: 1ith/thick Prospect Mt quartzite (6pm) massive very well indurated brownish gzite with some limestone.

4. To po maps: $1^{\circ} \times 2^{\circ}$ Lund $15^{\prime}$ Troy Canyon $7-1 / 2^{\prime}=$

5. Other -Sec -Twnship =Range =-

6. Distr-Brng $2000 \mathrm{~m}\left(6000^{\prime}\right)$, N70E from SE corner (surveyed) Sec 25, T6N, R56E

7. Exp area \& dimensions $0.5 \mathrm{~km}^{2}\left(0.2 \mathrm{mi}^{2}\right) 2.0 \mathrm{~km}(\mathrm{~N}-\mathrm{S}) \times 0.25 \mathrm{~km}(\mathrm{E}-\mathrm{W})(1.25 \mathrm{mi} \times 0.16 \mathrm{mi})$. \% Bedrock exp 15; much of mapped area is float covered.

8. Stratigraphy (Estimated From foot traverse_ Measured =-

9. Unit-thickness exp $\sim 300^{\prime}$ exposed; very folded \& deformed. Fn-grn\% See Item 13 . Clay-mineral rich \% Probably 0 .

10. Lat continuity Unknown; complex structurally. Induration and Colors Greenish gray to dark gray, hard \& brittle.

11. Thickness-clay horizon NA

12. Samples \& locations None

13. Other Lithologies Pioche shale in this area is approx equal amounts of slaty calcareous limestones, limy siltstones, \& gray phyllite. Phyllite becomes increasingly knotty (cordierite ?) \& schistose to E probably related to proximity to semiconcordant Troy Canyon granitic intrusive.

14. "Bedding" Foliation (may or may not be bedding) tends to strike NNE (approx parallel to range margin) with very wide variation of dip indicating much inlenal folding.

15. Fissl/Cleavage/Foliation Phyllites show well-developed metamorphic cleavage (phyllitic to schistose) \& calcareous slates show moderately well-developed slaty cleavage.

16. Contacts/Boundaries Base Not exposed. Fault with 6 pm on w margin of area.

17. Top Not exposed. Fault with Ge on E margin of area.

18. Other $\epsilon_{p}$ outcrop area is a fault slice that is elongate approx parallel to range margin. Metamorphism suggest granitic intrusive of Troy Canyon lies at shallow depth beneath $6 p$. Unit pinches out between faults to $S$.

19. Structure. Best map reference Cebul1, S. E. (1970). "Bedrock Geology \& Orogenic Succession in the Southern Grant Range, Nye County, Nevada," Am Assoc Petroleum Geol Bulletin 54, No. 10, 1:143,000; also see Kleinhampl \& Ziony (1967). "Preliminary Geologic Map of Northern Nye County, Nevada," USGS Open File Map $(1: 200,000)$.

20. Regional Setting Area. lies on $W$ flank of southern Grant Range, a generally E-tilted fault block range internally modified by low-angle faults, granitic intrusions, high-angle faults 
FIELD RECONNAISSANCE CHECKLIST (cont)

Locale Designation $\mathrm{NN}-6 \mathrm{E}$

Sublocale Name Troy Canyon

\& Tertiary volcanics. Area is part of "lower structural level" of Cebul1 (1970), which has been subjected to two phases of deformation \& metamorphosis (\& two accompanying phases of granitic intrusion). Area is on $S$ margin of Troy Canyon Lenco-gz Monzonite pluton.

21. Faults $6 \mathrm{p}-G e$ fault is high-angle fault, down on $E$ (?), which is strongly silicified. GP fault on $W$ is a complex zone characterized by slices in $\epsilon p$, generally nonsilicified. Geometric relation suggests $6 p-6 e$ fault predated Troy Canyon intrusion \& fault on $W$ postdated intrusion. Line of flowing springs \& wells 1 ie $2 \mathrm{mi}$ NW of area, parallel range \& generally lie on the margin of a subtle topographic break. This implies that springs lie on pediment-Railroad Valley fault margin.

22. Joints No uniform orientation noted, but fractures at high angle to foliation are common.

23. Folds No large-scale folds noted but $\epsilon p$ shows common smal1-scale tight-to-close folds \& locally intense small-scale crenulations of foliation.

24. Topography Area is located on W edge of Grant Range bordering steep pediment sloping WNW into Railroad Valley.

25. Slopes, max-min In outcrop area to $W, \sim 25 \%\left(14^{\circ}\right)$; in pediment $\sim 5 \%\left(3^{\circ}\right)$ Est imated Avg --

26. Ridge gradients Slopes in range vary $25 \%-80 \%\left(14^{\circ}-40^{\circ}\right)$ Lengths =-

27. Stm gradients Troy Canyon $\mathbf{S t m}$ Channel width =-

28. Dist.-brng to major topo break Area lies in range margin. Pediment-alluvium border $\sim 3$ mi to NW.

29. Miscellaneous: Access rte From Currant: follow graded dirt road SSW along $w$ front of Grant Range, $-10.7 \mathrm{mi}$. Turn ESE at sign for Troy Canyon Mine; follow unmaintained trail $2.6 \mathrm{mi}$. Ep outcrops are in mountain front to $\mathrm{s}$.

30. Known drill holes None noted.

31. Known springs Numerous flowing springs \& wells lie at base of pediment, $\sim 3 \mathrm{mi}$ to NW of area. Troy Canyon is deeply incised \& occupied by spring-fed perennial stream.

32. Mines (active/abandoned) Troy Canyon area is dotted with numerous abandoned mines \&

33. Prospects/claims prospects \& has been historically productive ( $W$, Au, lesser $\mathrm{Zn}$, $\mathrm{Ag}, \mathrm{Pb})$; claims are presumably patented, but presently inactive.

34. Mineralization/alteration Silicification along faults is abundant. District mineralization appears to be related to replacement of Eldorado Limestone ( $6 \mathrm{e}$ ); possibly related to intrusion.

35. Possible subsurf proj $\epsilon_{p}$ appears to be fault-banded \& probably does not project in subsurface.

36. Possible testhole sites None

37. Possible geophysical sites None

38. Other --

Geologist J. Connolly Organization UNM Date $5 / 22 / 79$ 
FIELD RECONNAISSANCE CHECKLIST

Phase II Investigations: Fine-Grained (fn/grn)

Clastic Sedimentary Rocks and Metamorphic

Derivatives in Eastern Nevada
Locale Designation $\mathrm{NN}-6 \mathrm{~F}$

Sublocale Name Mud Spring Basin

1. Stratigraphic name/

designator Pioche Shale ( $\theta p)$

2. Unit above: lith/thick Eldorado Limestone ( $6 \mathrm{e}$ ) or Pole Canyon Limestone ( $6 \mathrm{pc}$ ). Previous nomenclature per Cebull (1970), later per Kleinhampl \& Ziony (1967). 6p is also unconformably overlain by Quat-Tertiary Basalt Flows (QTb).

3. Unit below: lith/thick Prospect Mt Quartzite ( $6 \mathrm{pm}$ )

4. Topo maps: $1^{\circ} \times 2^{\circ}$ Lund

$15^{\prime}$ Troy Canyon $7-1 / 2^{\prime}=$

5. Other -$\operatorname{Sec} \mathrm{E} 1 / 2 \operatorname{Sec} 34$ Twnship $7 \mathrm{~N}$ Range 57E

6. Distr-Brng =from --

7. Exp area \& dimensions $-3.6 \mathrm{~km}^{2}\left(1.4 \mathrm{mi}^{2}\right)$. Approx additional $2.5 \mathrm{~km}^{2}\left(1 \mathrm{mi}^{2}\right)$ is on pediment probably underlain at shallow depth by $\theta_{p}$. Exposure dimensions are $\sim 1.6 \mathrm{~km}$ (WNW) $2.4 \mathrm{~km}$ (NNE) $(1 \mathrm{mi} \times 1.5 \mathrm{mi})$.

\%Bedrock exp 10 or 1ess. Most $1 y$ covered by QP; good exp in Terrel1 Mine Canyon.

8. Stratigraphy (Estimated By foot traverse Measured --

9. Unit-thickness exp $\sim 150 \mathrm{~m}\left(500^{\prime}\right)$. All exposed rocks are phyllitic slates \& phyllite. Fn-grn\% $\sim 50$ Clay-mineral rich \% Probably none

10. Lat continuity Probably poor (see structure)

Induration and colors slates tend to be grayish brown, very brittle.

11. Thickness-clay horizon Unknown

12. Samples \& locations None taken.

13. Other Lithologies No clay shales present in sequence. From limited exposures in deeper washes, $6 p$ appears to be $-50 \%$ limestone (generally bluish gray) \& $50 \%$ slate. All slate samples are very calcareous.

14. "Bedding" N9OE, 42N in slaty limestone 6e; N5E, 25E pyritic slaty limestone 6e; N90W, 16N casts shaley limestone with pyrite 6e; 6e N30W, 23NE flaggy limestone; N40W, 35NE calcareous slate $e_{\mathrm{P}} \mathrm{N} 30 \mathrm{~W}, 45 \mathrm{NE}$ calcareous slate $6 \mathrm{p}$.

15. Fiss $/ / \mathrm{Cl}$ eavage/.Foliation slates are $\mathrm{slaty}$; cleave into thin $(\sim \mathrm{l}$ m) plates. Limestones tend to be more thickly flaggy.

16. Contacts/Boundaries Base Not observed. Shown as thrust fault by Kleinhampl \& Ziony with G.pm.

17. Top Is in contact with $\epsilon e$ (or $\epsilon_{p c}$ ) but "bedding" strikes oblique to contact suggesting structural origin. Lithologic variation suggests strat contact is gradation with transition marked by increase in limestone.

18. Other Overlain by small basalt flow. Overlapped \& covered to $W$ by extensive pediment gravels \& alluvium. 
F IELD RECONNAISSANCE CHECKLIST (cont)

Locale Designation NN-6F

Sublocale Name Mud Spring Basin

19. Structure. Best map reference Kleinhampl \& Ziony (1967). "Preliminary Geologic Map of Northern Nye County, Nevada," USGS Open File Map. Al so see Cebull, S. E., (1970). "Bedrock Geology \& Orogenic Succession in Southern Grant Range, Nye County, Nevada," AAPG Bulletin 54, p 1828-1842 (Map of area just S of Grant Canyon, Fig. 14. Scale 1:125,000).

20. Regional Setting Area lies on W flank of Grant Range; a generally E-tilted fault block range that has been internally modified by low-angle. faults, "lower structural level" of Cebu11 (1970), which has been subjected to two phases of deformation $\&$ metamorphism ( $\&$ accompanying granitic intrustions). Area is on $\mathrm{N}$ margin of Troy Canyon Lenco-Qz monzonite pluton.

21. Faults No large-scale faults observed but wide variation in foliation-bedding orientation \& lineation orientation suggesting int deformation by faulting. Area mapped by Kleinhampl

$\&$ Ziony as fault-bounded on both the $N \& S$. Line of springs (Thorn Spr., Bullwhacker Springs) at foot of pediment $\sim \mathrm{mi}$ to NW strongly suggests range marginal fault \& suggests Ep may continue in subsurface to this. locale. Several small-scale faults with generally low, mostly westward, dips observed in some outcrops.

22. Joints $6 e \& G p$ limestones have abundant calcite-filled fractures.

23. Folds $1,2 \& 3$ in $6 \mathrm{p}$; small-scale fold axes: (1) $\mathrm{pl} 34^{\circ}, \mathrm{N} 10 \mathrm{~W} ;$ (2) $\mathrm{pl}-10^{\circ}$, S50E pitch swell met lineation; (3) $\mathrm{p} 1 \sim 15^{\circ}$ due $\mathrm{N}$ fold axis $0.5-\mathrm{m}$ : amplitude, $0 \mathrm{pa}$, in $\epsilon_{\mathrm{p}}$ : fold axes (pencil cleavage): p1 $25^{\circ}$, N1OW.

24. Topography Area is one of numerous WNW-trending canyons \& intervening ridges surr. on NW, SE \& SW by rugged mountainous terrain \& on NW by pediment--alluvial fan complex.

25. Slopes, max-min See Item 26 Estimated Avg =-

26. Ridge gradients Avg, $8 \%(5 \%)$ to WNW Leng ths Some up to $1 \mathrm{~km}$, most few hundred meters.

27. Stm gradients Same as Item 26 Channel width 5-10 m

28. Dist.-brng to major topo break Outcrop lies on margin of pediment (slopes $6 \%\left(3^{\circ}\right)$ to WNW). $1000 \mathrm{~m}\left(3500^{\prime}\right)$ WNW to alluvial fan of Railroad Valley.

29. Miscellaneous: Access rte From Currant; proceed $10.4 \mathrm{mi}$ SW on US 6 to Eagle Springs turnoff. Continue E $\sim 6.2 \mathrm{mi}$ past oil field to Jct W Nyala Rd. Turn SW toward Nyala \& continue $12.9 \mathrm{mi}$ (sign for Grant Canyon at $11.7 \mathrm{mi}$ ) to graded dirt road. Turn SE through gap $1.9 \mathrm{mi}$ to Mud Springs: $6 p$ outcrops between here \& road to $W$.

30. Known drill holes None seen, but probably present.

31. Known springs Mud Spring flows with $\sim 8$ to 5 -gal/min flow.

32. Mines (active/abandoned) Terrell Mine (abandoned) was smal1 open-pit operation.

33. Prospects/claims Numerous old claim stakes \& monuments; Terrell claims probably patented.

34. Mineralization/alteration Abundant pyrite present in $6 e$ limestones; Terrel1 Mine appears to be $Q z$-pyrite veins (?) in altered $6 e$ \& phyllite (?).

35. Possible subsurf proj Probably underlies pediment as far as spring to $W$. 
F IELD RECONNAISSANCE CHECKLIST (cont)

Loc ale Designat ion NN-6F

Sublocale Name Mud Spring Basin

36. Possible testhole sites =-

37. Possible geophysical sites =-

38. Other --

Geologist J. Connolly 
DISTRIBUTION:

DOE/TIC-4500(Rev 69) U-7.0 (325)

US Department of Energy (3).

Office of Waste Isolation

Germantown, MD 20767

Attn: C. A. Heath, Director Rm B-207

C. R. Cooley, Deputy Direcțor $\mathrm{Rm} \mathrm{B-214}$

D. L. Vieth, Actg Tech Team Leader, $\mathrm{Rm} B-220$

US Department of Energy

National Waste Terminal

Storage Program office

505 King Ave

Columbus, $\mathrm{OH} 43201$

Attn: J. O. Neff, Program Manager

Lawrence Livermore National Lab (2)

University of California

P.O. Box 808

Livermore, CA 94550

Attn: L. D. Ramspott, Technical

Project Officer, MS L-204

K. Street, Jr, MS L-209

Los Alamos National Lab (2)

University of California

P.0. Box 1663

Los Alamos, NM 87545

Attn: B. R. Erdal, Technical

Project Officer, MS 514

D. C. Hof fman, MS 760

Westinghouse - AESD

P.0. Box 708, Mail stop 703

Mercury, NV 89023

Attn: A. R. Hakl, Site Mgr

US Geological Survey (2)

P.0. Box 25046, MS 954

Federal Center

Denver, CO 80301

Attn: G. L. Dixon, Tech Project Officer

W. E. Wilson 
Distribution (cont):

W. S. Twenhofel

820 Estes St

Lakewood, CO 80226

US Department of Energy

Richland Operations Office

P.O. Box 550

Richland, WA 99352

Attn: R. G. Goranson

Rockwell International Atomics

International Division

Rockwel1 Hanford Operations

Richland, WA 99352

Attn: R. Deju

US Department of Energy (13)

P. 0. Box 14100

Las Vegas, NV 89114

Attn: R. M. Nelson, Jr (3)

Director, Waste Mgmt

Project Office

D. F. Miller, Director Office of Public Affairs

R. H. Marks, $\mathrm{CP}-1$, MS 210

B. W. Church, Director Health Physics Division

R. R. Loux (7)

Holmes \& Narver, Inc

P.0. Box 14340

Las Vegas, NV 89114

Attn: A. E: Gurrola

Battelle ( 8 )

Office of Nuclear Waste Isolation

505 King Ave

Columbus, OH 43201

Attn: N. E. Carter

W. A. Carbiener

3. Gold 9mith

ONWI Library (5)

State of Nevada

Capitol Complex

Goverior's Officc of Planning Snnrdination

Carson City, NV 89023

Attn: R. M. Hill, State Planning Coordinator 


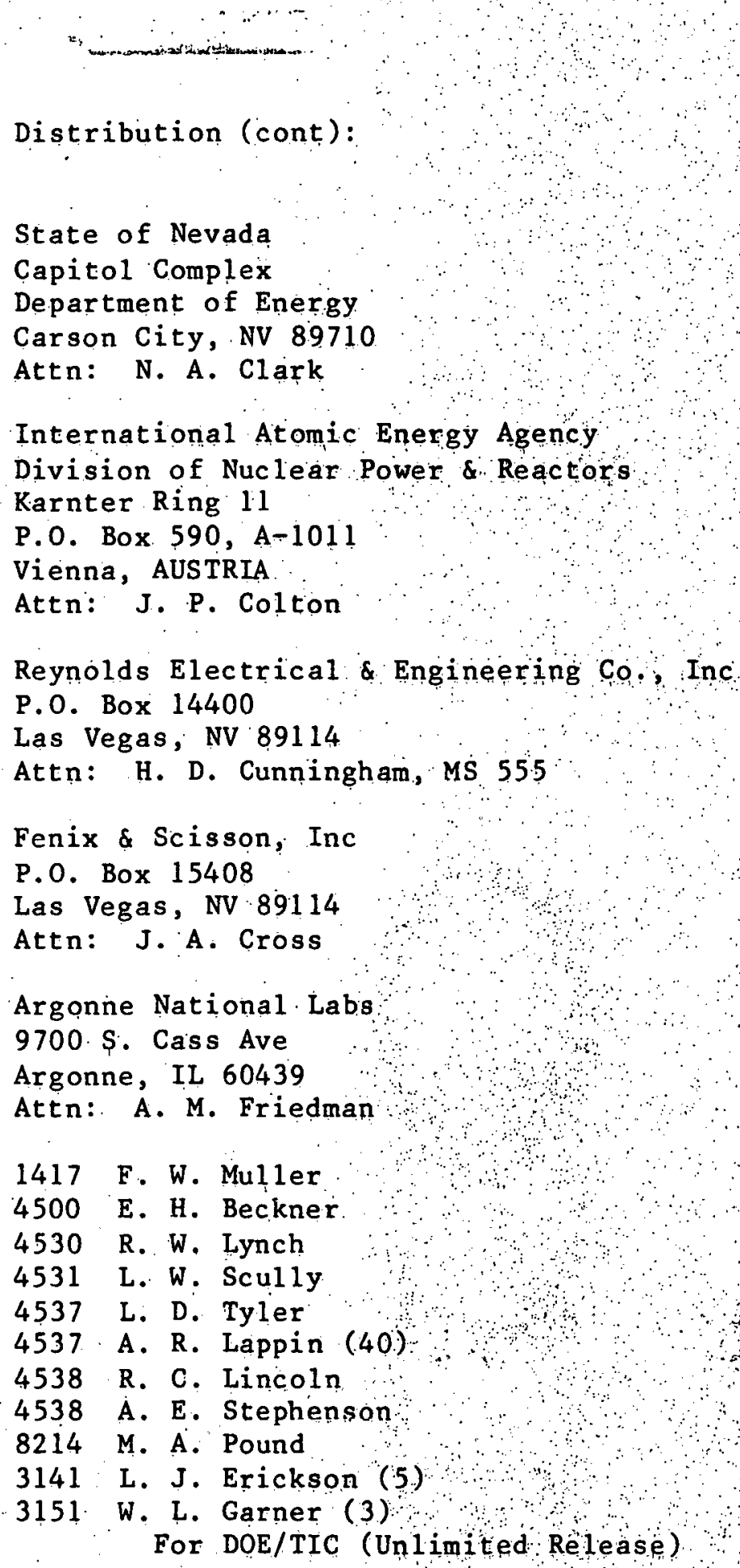

